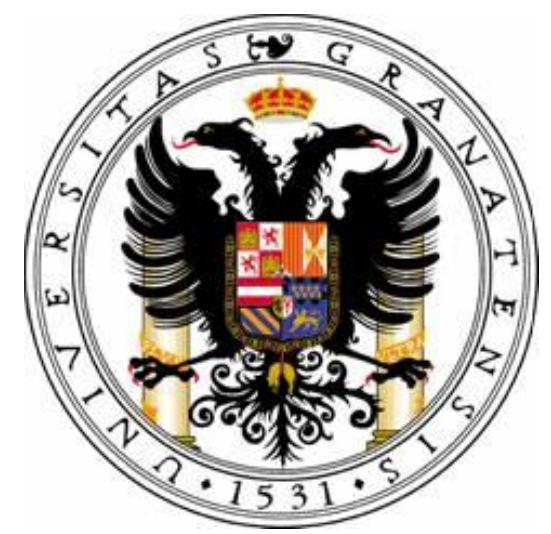

UNIVERSIDAD DE GRANADA

Máster Universitario Oficial en Profesorado de Educación Secundaria Obligatoria, Bachillerato, Formación Profesional y Enseñanza de Idiomas.

Especialidad en Filosofía

Unidad Didáctica:

\title{
Naturaleza, cultura y el reto intercultural
}

\author{
Trabajo Fin de Máster
}

Autora: Érika Janet FIURI MARTÍNEZ

Directora: María del Carmen LARA NIETO

Granada, Junio de 2012 


\section{ÍNDICE}

1. INTRODUCCIÓN A LA MATERIA Y JUSTIFICACIÓN EN EL MARCO LEGAL

1.1. Introducción

2. JUSTIFICACIÓN NORMATIVA DE LA UNIDAD DIDÁCTICA PROPUESTA

3. CONTEXTUALIZACIÓN

3.1. Fundamentación de la U.D.

3.2. Características del alumnado al que va dirigida la U.D.

3.3. El entorno escolar: recursos materiales.

3.4. Vinculación del currículo de Filosofía y Ciudadanía con el Proyecto Educativo del Centro y con la Programación Anual del Departamento de Filosofía

4. OBJETIVOS

5. CONTENIDOS

5.1. Elementos de aprendizaje de la U.D.

5.2. Esquema de Contenidos

6. TEMPORALIZACIÓN.

7. COMPETENCIAS BÁSICAS.

8. METODOLOGÍA.

9. RECURSOS

10. ATENCIÓN A LA DIVERSIDAD

11. EDUCACIÓN EN VALORES.

12. CRITERIOS DE EVALUACIÓN 
12.1. Criterios de evaluación generales

12.2. Criterios de evaluación específicos.

12.3. Instrumentos de evaluación.

12.4. Criterios de calificación

13. DESARROLLO DE LAS SESIONES.

13.1. Desarrollo de los contendidos de la U.D.

14. BIBLIOGRAFÍA

14.2. Bibliografía de aula. 


\section{Comisión evaluadora:}

Presidente: Miguel Moreno Muñoz

Vocal 1: María Teresa Lara

Vocal 2: Antonio J. Lucas Ruiz

Fecha de defensa: 26 de junio de 2012 


\section{Agradecimientos}

Mi agradecimiento a María del Carmen Lara Nieto por su esfuerzo y lucha por mantener la especialidad de Filosofía en el Máster de Secundaria.

Mi reconocimiento y admiración a Paloma García Díaz. Reconocimiento por su dedicación a las clases que impartió y su incondicionalidad. Admiración y agradecimiento por su pertinente y eficaz colaboración en este trabajo. 


\section{INTRODUCCIÓN A LA MATERIA Y JUSTIFICACIÓN EN EL MARCO LEGAL}

\subsection{Introducción}

La realización de la presente Unidad Didáctica nace de la necesidad de desarrollar un plan didáctico de acción real que pueda responder a la configuración heterogénea y plural que están adquiriendo nuestras sociedades, propiciando el aprendizaje de los valores interculturales y del diálogo como mecanismos que ayudarán a los alumnos/as a desarrollarse, integrarse e integrar al Otro. En esta medida, la U.D. se configura en torno a dos vertientes: por un lado, pretende introducir al alumnado en el estudio del ser humano haciendo confluir las aportaciones de la antropología y de la sociología, dando cuenta de la evolución cultural del ser humano, así como de los mecanismos de socialización necesarios para el desarrollo de la identidad personal y social de las personas; por otra parte, desde un enfoque más puramente filosófico, se plantean los interrogantes subyacentes a estos procesos: ¿qué es la identidad personal?, ¿cuáles son los enfoques filosóficos que abordan la sociabilidad humana?, ¿qué significa la necesidad de reconocimiento y la intersubjetividad?, ¿por qué necesitamos aprender a convivir? Finalmente, estas dos vertientes confluyen en el objetivo final de la U.D: el reto intercultural.

La interculturalidad supone un reto, dado que implica aceptar un nuevo paradigma de organización social en el que los valores democráticos, la participación, el empoderamiento, la ciudadanía activa y la democracia deliberativa, conforman un tándem que intenta hacer frente, de la mejor manera posible, a una realidad heterogénea, multiétnica y multicultural.

Nos enfrentamos a la configuración de sociedades diversas y plurales, que en su proceso de redefinición generarán situaciones de conflicto. El conflicto es inherente a todo contacto cultural, y en sí mismo no es un problema, pero sí lo es la manera en la que percibimos y respondemos a esos conflictos. Los discursos científicos ${ }^{1}$ sobre los encuentros interculturales, señalan que la presencia de otras culturas es percibida como problemática en la medida en que se producen encuentros de ideologías, culturas, clases sociales y sobre todo, encuentros de intolerancia. Esto ha dado lugar a manifestaciones de racismo, discursos xenófobos y la más usual de todas, manifestaciones de etnocentrismo. De ahí la necesidad de desarrollar medidas que nos permitan prevenir y aminorar estas problemáticas. Una de las herramientas que debemos desarrollar es la educación en el respeto a la pluralidad, en el entendimiento de la diferencia y la aceptación del otro. El ámbito educativo es

\footnotetext{
${ }^{1}$ A continuación, menciono algunos de los trabajos en los que sustento mi afirmación: GONZÁLEZ R. ARNAIZ, Graciano (2008): Interculturalidad y convivencia, Biblioteca Nueva, Madrid. GARCÍA CASTAÑO, F.J. et al., (próxima publicación). Inmigración extranjera y escuela en Andalucía. Diferencias que terminan siendo desigualdades. GARCÍA CASTAÑO, F.J. y MONEREO PÉREZ, J. L. (dirs.). La inmigración en Andalucía. Instituciones, aspectos jurídico-sociales y culturales, Comares, Granada.

GARCÍA CASTAÑO, F.J. et al., (1999). La educación multicultural y el concepto de cultura. GARCÍA CASTAÑO, F.J. y A. GRANADOS MARTÍNEZ, Lecturas para educación intercultural, Trotta, Madrid.
} 
un lugar privilegiado para desarrollar e implementar medidas que ayuden a educar a los jóvenes y facilitar la integración y convivencia. Porque la tarea no sólo la tiene el inmigrante que ha de aprender a vivir en su país de acogida adaptándose lo mejor que pueda socioculturalmente sino que también supone un esfuerzo de las poblaciones de acogida que consiste en respetar la diversidad cultural y étnica.

Por otra parte, pero en íntima relación con lo anterior, esta U.D. se propone continuar con el estudio de la ciudadanía que se había iniciado en la etapa de enseñanza básica. De esta manera, se seguirá una orientación hacia una filosofía social, moral y política que pretende construir una ciudadanía activa, informada, respetuosa, crítica, reflexiva y responsable.

Esta U.D está diseñada para ser implementada en 1으 de Bachillerato. Se parte de la consideración de que el alumnado de Bachillerato se hallaría en condiciones de comprender e interpretar los contenidos de esta U.D, en la medida en que ya ha tenido un primer contacto somero, con los contenidos aquí abordados, en Educación Ético-Cívica y en Educación para la Ciudadanía y los Derechos Humanos en la Educación Secundaria Obligatoria y en Educación Primaria. La reflexión filosófica que se realiza de modo transversal a lo largo de todas las sesiones previstas, aspira a la promoción activa de los valores ciudadanos, así como de las competencias necesarias para la formación de la personalidad crítica y reflexiva del alumnado. En este sentido, la sistematización de las preguntas y las respuestas que se ofrecen, se presentan como una actividad comprometida con nuestra época y circunstancias sociales, manteniendo como guía el esfuerzo de comprensión de la realidad.

\section{JUSTIFICACIÓN NORMATIVA DE LA UNIDAD DIDÁCTICA PROPUESTA}

El Real Decreto 1467/2007, de 2 de noviembre, aprobado por el Ministerio de Educación y Ciencia (MEC) y que establece la estructura y las enseñanzas mínimas de Bachillerato como consecuencia de la implantación de la Ley Orgánica de Educación (LOE), ha sido desarrollado en la Comunidad Autónoma de Andalucía por el Decreto 416/2008, de 22 de julio, por el que se establece la ordenación y las enseñanzas correspondientes al Bachillerato, y por la Orden de 5 de agosto de 2008, por la que se desarrolla el currículo de Bachillerato para esta comunidad. En el artículo 2 de esta Orden se indica que los objetivos, contenidos y criterios de evaluación para cada una de las materias son los establecidos tanto en ese Real Decreto como en ese Decreto y en esa Orden, en la que, específicamente, se incluyen los contenidos propios de esta comunidad, que "versarán sobre el tratamiento de la realidad andaluza en sus aspectos geográficos, económicos, sociales históricos, culturales, científicos y de investigación a fin de mejorar las competencias ciudadanas del alumnado, su madurez intelectual y humana, y los conocimientos y habilidades que le permitan desarrollar las funciones sociales precisas para incorporarse a la vida activa y a la educación superior con responsabilidad, competencia y autonomía". El presente documento se refiere a la programación de la materia común de Filosofía y Ciudadanía en el primer curso de Bachillerato.

La presente Unidad Didáctica podría insertarse en el Bloque III: El ser humano: persona y sociedad, así como también, podría formar parte del Bloque V: Democracia y ciudadanía. 
Las cuestiones que han motivado la construcción de esta U.D., son las recogidas en la ORDEN de 5 de agosto de 2008, por la que se desarrolla el currículo correspondiente al Bachillerato en Andalucía. Específicamente, las siguientes problemáticas:

-¿Por qué se dice que el ser humano es persona? ¿Cuáles son los rasgos esenciales de la persona? ¿Cómo se ha ido formando a través de la historia la noción de persona? ¿Qué significa que la persona es un sujeto de derechos y de deberes?

- ¿Qué diferencia existe entre ser iguales en derechos y deberes y ser iguales en raza, sexo, cultura, etc.?

- ¿Cómo se debe recibir hoy a los emigrantes?, ¿qué limites a sus costumbres les puede poner el Estado democrático de acogida?, ¿se puede exigir a los emigrantes ciertos requisitos para su integración en un país democrático y de Derecho?, ¿se deben tolerar las ideas y los estilos de vida minoritarios, siempre que no perjudiquen a los demás o, por el contrario, debemos imponer nuestras ideas y estilos de vida por considerarlos mejores?

Además de los objetivos enumerados en el artículo 33 de la Ley Orgánica 2/2006, de 3 de mayo, de Educación, los siguientes se consideran especialmente relevantes para el desarrollo de la U.D. Tal y como dictamina el artículo 4 del Decreto 416/2008, de 22 de julio, por el que se establece la ordenación y las enseñanzas correspondientes al Bachillerato en Andalucía, se contribuirá a desarrollar en el alumnado las habilidades necesarias para consolidar su autonomía personal, tanto a nivel familiar como social, para que pueda participar de la vida social con actitudes solidarias, tolerantes y libres de prejuicios. Asimismo, en el artículo 6 del citado Decreto, se determina que la orientación del Bachillerato perseguirá desarrollar de forma integral, las capacidades y actitudes necesarias para comprender la sociedad en la que vive y poder actuar en ella de manera justa y solidaria. También se hace hincapié en el fortalecimiento del respeto de los derechos humanos, libertades y valores necesarios para que el alumnado pueda asumir una vida social democráticamente activa, en una sociedad equitativa y libre.

\section{CONTEXTUALIZACIÓN}

\subsection{Fundamentación de la U.D.}

La presente U.D. se nutre de las aportaciones de la antropología y de la sociología, pero lo hace desde el peculiar punto de vista de la filosofía. Para ello se hace uso de las aportaciones y conocimientos que ya han sistematizado otros autores, en concreto Francisco Javier García Castaño y Graciano González R. Arnaiz. La elección de estos autores se justifica en la medida en que ellos representan figuras relevantes en el terreno de estudios de antropología cultural y de filosofía centrada en la reflexión sobre la interculturalidad, respectivamente. Así pues, mediante el estudio de libros como Interculturalidad y convivencia y El discurso intercultural. Prolegómenos a una filosofía intercultural, hemos obtenido una valiosa y pertinente aportación filosófica sobre el reto que representa la elaboración de una ciudadanía que secunde los valores interculturales, así como un 
estudio sobre la importancia de la alteridad, del reconocimiento, de la condición de extranjero y de la convivencia. Por otro lado, Lecturas para la educación intercultural de Francisco Javier Castaño supone la fuente principal para el análisis de la práctica intercultural desde la perspectiva de la antropología de la educación (subdisciplina del tronco general de la antropología social y cultural).

Finalmente, la adaptación de los contenidos mencionados, así como de aquellos contenidos que hacen referencia a la naturaleza social del ser humano y al funcionamiento de la sociedad, al alumnado de primero de Bachillerato, ha tenido como referencia los libros de texto de Bachillerato, especialmente Filosofía Bachillerato de Guadiel y Filosofía y ciudadanía 1ㅇ de Bachiller de Santillana. Se justifica la referencia a estos libros de textos en la medida en que en el desarrollo de sus contenidos demuestran una gran claridad expositiva no exenta de la complejidad adecuada para el nivel de Bachillerato.

El resultado de la confluencia de las aportaciones mencionadas ha permitido elaborar un material que tiene la finalidad de captar la atención del alumnado en lo que concierne a la definición del ser humano, su inserción en la sociedad y la problemática intercultural. Estos objetivos también se hayan plasmados en el diseño de las diversas actividades.

\subsection{Características del alumnado al que va dirigida la U.D.}

Esta unidad didáctica está dirigida a los alumnos y alumnas de primer curso de Bachillerato. Estos alumnos/as pertenecen al I.E.S. Ángel Ganivet, un centro educativo ubicado en el centro de la ciudad de Granada.

Según los datos consultados en el PAC, los alumnos/as tanto del Régimen General como el de Adultos y Ciclos Formativos constituyen un colectivo heterogéneo en cuanto a sus diferencias sociales, económicas y de procedencia geográfica. El documento recoge que sólo 111 pertenecen al área adscrita al Centro, en tanto que el resto proceden de las demás zonas de la ciudad, 302, al área metropolitana y provincia 423 o a otras provincias 63 , contabilizados en los distintos distritos.

Del conjunto del alumnado 444 son chicos; las restantes 460 , chicas. Ha habido un notable incremento en la matriculación del Régimen de Adultos, en la procedencia metropolitana y del resto de la provincia. Intentar hacer un estudio de sus entornos, sus características, etc. no resulta fácil si no es a través de los informes que la Jefatura de Estudios ha ido cotejando de los diversos tutores, en los que se ha podido observar la disparidad de procedencias tanto a nivel cultural como social. Al pertenecer a Hacienda los datos privados de cada familia no se ha podido acceder, como antes se hacía, a los datos económicos lo que dificulta la tarea de reseñar con exactitud el perfil económico del alumnado. Se puede decir, a grandes rasgos que el alumnado tiene un nivel de clase media, y que la sociedad granadina, en general, está reflejada en el alumnado.

Mención especial merecen los alumnos con Necesidades Educativas Especiales, a los que se dedica loable labor tanto por el Equipo de Orientación como por el Servicio A.T.A.L.

Centrándonos en el alumnado de 1을 de Bachillerato, mencionar que las edades de estos jóvenes oscilan entre los 16-17 años. Los alumnos y alumnas en la medida en que han obtenido el título de 
Graduado en ESO, manifiestan haber adquirido unas competencias básicas mínimas en los niveles intelectual y cultural que posibilitarán la adquisición de las capacidades que el Decreto 461/2008 fija para el Bachillerato. En la Etapa anterior han adquirido ciertas herramientas que facilitarán el aprendizaje de los nuevos contenidos. Si bien, el Bachillerato exige del alumnado la consolidación del manejo del pensamiento abstracto, de la disertación filosófica, de la expresión tanto oral como escrita, entre otras. Pero la finalidad fundamental a la que van dirigidos los esfuerzos de esta etapa no son sólo los estrictamente cognitivos o intelectuales, sino que, su desarrollo personal se presenta como un desafío primordial para el docente, quien debe incidir de forma activa y explícita desde la acción educativa en la adopción de actitudes y valores que desde el pluralismo, el reconocimiento de la diferencia, la aceptación de la igualdad, la libertad, la justicia, y la responsabilidad, contribuyan a crear una sociedad más equitativa y justa. De esta forma, se trata de apoyar la madurez intelectual y humana del alumnado, actuando como una guía del pensamiento y de los valores, para que al finalizar el Bachillerato, los conocimientos y habilidades adquiridas les permitan desempeñar sus roles sociales siendo personas integrales y competentes.

\subsection{El entorno escolar: recursos materiales}

El I.E.S. Ángel Ganivet cuenta con la mención de Centro Tic y Bilingüe, por lo tanto, sus instalaciones están organizadas acorde a las necesidades del centro y teniendo en cuenta que estas dos menciones específicas requieren el uso de materiales informáticos y didácticos concretos. EL centro cuenta con una red de ADSL que provee de Internet a todo el centro, utilizando el sistema de Guadalinfo.

Respecto al mobiliario y equipamiento, mencionar que el centro se halla muy bien equipado. Prácticamente todas las aulas cuentan con un cañón proyector y con pizarras electrónicas, material audiovisual e informático que facilita la tarea docente. La distribución de los recursos cubre equitativamente las necesidades generales. Por otra parte, el centro consta de un servicio de reprografía centralizado en conserjería; no obstante, en los departamentos, sala de profesores y dependencias de administración también se encuentran impresoras.

\subsection{Vinculación del currículo de Filosofía y Ciudadanía con el Proyecto Educativo del Centro y con la Programación Anual del Departamento de Filosofía}

Para integrar mi Unidad Didáctica en los niveles superiores del Proyecto Educativo de Centro (PEC), y en la Planificación Anual del Departamento de Filosofía, paso a referir las Finalidades Educativas de éste y a los Objetivos Generales allí recogidos. Mencionar que he seleccionado aquellas finalidades y objetivos que son pertinentes para la materia de Filosofía y ciudadanía, en la cual se inserta la U.D.

Finalidades educativas del PEC:

Sobre la formación personal y en valores del alumnado: 
- Promover el espíritu crítico.

- Promover actitudes de tolerancia y respeto mutuo.

- Promover la solidaridad y responsabilidad.

- Estimular la capacidad de apreciar la cultura regional y local con espíritu de universalidad.

\section{Objetivos del Departamento de Filosofía:}

-Desarrollar en el alumnado la capacidad de análisis racional y favorecer la adquisición de un hábito de reflexión que les ayude a orientarse en la vida.

-Preparar a ciudadanos críticos y creativos que puedan contribuir en la construcción permanente de la sociedad democrática en la que deben vivir.

- Hacer del diálogo la herramienta constructiva de un mundo mejor

-Saberse y comprenderse ciudadanos de este mundo global

-Dar respuestas a conceptos de nuestra vida: el universo como totalidad, el significado de la existencia, el ser humano y su condición de ciudadano, los contenidos simbólicos de la cultura (ciencia, arte, filosofía), la conciencia, materia, espíritu, persona, naturaleza, cultura, verdad, libertad, democracia, estado de derecho, persona, justicia, dialéctica, relativismo cultural, multiculturalismo, etnocentrismo, homofobia, ecologismo.

-Adquirir y dominar el arte argumentativo.

\section{OBJETIVOS}

Los objetivos son una parte crucial de la presente U.D. ya que su consecución es la finalidad de la misma. En primer lugar, mencionaremos los objetivos generales del Bachillerato a los que nos atenemos prioritariamente. En segundo lugar, se señalan los objetivos específicos de la U.D., objetivos que están orientados a la adquisición de aprendizajes propios de los contenidos a desarrollar durante la U.D. Ambos objetivos, tanto los generales como los específicos, se combinan y concuerdan entre sí para hacer del proceso de aprendizaje una práctica exitosa.

Además, los objetivos planteados para esta U.D. tienen como referencia el Real Decreto 1467/2007, de 2 de noviembre, aprobado por el Ministerio de Educación y Ciencia (MEC) y que establece la estructura y las enseñanzas mínimas de Bachillerato y la Orden 5 de agosto de 2008 por la que se establecen los contenidos del bachillerato en la Comunidad Autónoma de Andalucía.

\section{A) Objetivos generales del Bachillerato}

Objetivos promulgados por el artículo 33 de la Ley Orgánica de Educación (Ley 2/2006, de 3 de mayo) y en el artículo 3 del Real Decreto 1467/2007, de 2 de noviembre:

El bachillerato contribuirá a desarrollar en los alumnos y en las alumnas las capacidades que les permitan: 
a. Ejercer la ciudadanía democrática, desde una perspectiva global, y adquirir una conciencia cívica responsable, inspirada por los valores de la Constitución española así como por los derechos humanos, que fomente la corresponsabilidad en la construcción de una sociedad justa y equitativa y favorezca la sostenibilidad.

b. Consolidar una madurez personal y social que les permita actuar de forma responsable y autónoma y desarrollar su espíritu crítico. Prever y resolver pacíficamente los conflictos personales, familiares y sociales.

c. Fomentar la igualdad efectiva de derechos y oportunidades entre hombres y mujeres, analizar y valorar críticamente las desigualdades existentes e impulsar la igualdad real y la no discriminación de las personas con discapacidad.

d. Afianzar los hábitos de lectura, estudio y disciplina, como condiciones necesarias para el eficaz aprovechamiento del aprendizaje, y como medio de desarrollo personal.

e. Dominar, tanto en su expresión oral como escrita, la lengua castellana y, en su caso, la lengua cooficial de su comunidad autónoma.

f. Expresarse con fluidez y corrección en una o más lenguas extranjeras.

g. Utilizar con solvencia y responsabilidad las tecnologías de la información y la comunicación.

h. Conocer y valorar críticamente las realidades del mundo contemporáneo, sus antecedentes históricos y los principales factores de su evolución. Participar de forma solidaria en el desarrollo y mejora de su entorno social.

i. Acceder a los conocimientos científicos y tecnológicos fundamentales y dominar las habilidades básicas propias de la modalidad elegida.

j. Comprender los elementos y procedimientos fundamentales de la investigación y de los métodos científicos. Conocer y valorar de forma crítica la contribución de la ciencia y la tecnología en el cambio de las condiciones de vida, así como afianzar la sensibilidad y el respeto hacia el medio ambiente.

k. Afianzar el espíritu emprendedor con actitudes de creatividad, flexibilidad, iniciativa, trabajo en equipo, confianza en uno mismo y sentido crítico.

I. Desarrollar la sensibilidad artística y literaria, así como el criterio estético, como fuentes de formación y enriquecimiento cultural.

m. Utilizar la educación física y el deporte para favorecer el desarrollo personal y social.

n. Afianzar actitudes de respeto y prevención en el ámbito de la seguridad vial.

Podemos afirmar que el trabajo de esta U.D. en clase puede colaborar en la consecución de la mayoría de estos objetivos, sólo consideramos como fuera de nuestra competencia los objetivos f) y m). Por otra parte, la asignatura de Filosofía y ciudadanía, en la que se halla inserta la presente U.D. 
se haya relacionada con los objetivos del a) al e), el h) y j), y en esa medida, contribuirá a su aprendizaje.

A estos objetivos, el Decreto 461/2008 añade los siguientes:

a) Las habilidades necesarias para contribuir a que se desenvuelvan con autonomía en el ámbito familiar y doméstico, así como en los grupos sociales con los que se relacionan, participando con actitudes solidarias, tolerantes y libres de prejuicios.

b) La capacidad para aprender por sí mismo, para trabajar en equipo y para analizar de forma crítica las desigualdades existentes e impulsar la igualdad, en particular, entre hombres y mujeres.

c) La capacidad para aplicar técnicas de investigación para el estudio de diferentes situaciones que se presenten en el desarrollo del currículo.

d) El conocimiento y aprecio por las peculiaridades de la modalidad lingüística andaluza en todas sus variedades, así como entender la diversidad lingüística y cultural como un derecho y un valor de los pueblos y los individuos en el mundo actual, cambiante y globalizado.

e) El conocimiento, valoración y respeto por el patrimonio natural, cultural e histórico de España y de Andalucía, fomentando su conservación y mejora.

Podemos afirmar que al finalizar la U.D. el alumnado habrá conseguido la totalidad de estos objetivos, al tiempo que habrá desarrollado las siguientes capacidades:

\section{B) Objetivos específicos de la U.D.}

- Emplear con propiedad y rigor conceptos y términos específicos.

- Argumentar coherentemente.

- Ejercitar el diálogo filosófico y valorarlo como una herramienta práctica cuyo objetivo es el encuentro racional y la búsqueda colectiva de la verdad.

- Analizar textos filosóficos, antropológicos, sociológicos y periodísticos, captando, especialmente la peculiaridad del saber filosófico y distinguiéndolo de los otros saberes humanos.

- Argumentar a favor de la igualdad y el respeto de las diferencias, adoptando una actitud crítica ante todo intento de justificación de las desigualdades sociales y ante toda clase de discriminación.

- Respetar las costumbres y modos de vida ajenos.

- Delimitar conceptualmente las ideas de naturaleza y cultura.

- Ser capaz de comprender el significado de la identidad personal y su implicación con la identidad social y cultural en el proceso de conformación del ser humano. 
- Identificar las teorías filosóficas que explican la génesis social del ser humano y ser capaz de relacionarlas entre sí para captar similitudes y diferencias en los planteamientos.

- Reconocer la pluralidad cultural y la necesidad de adoptar una posición respetuosa con las diferencias.

- Entender las diferentes actitudes que se dan ante la diversidad cultural.

- Identificar los procesos de socialización.

- Percatarse de la idoneidad y pertinencia de la aproximación filosófica a la cultura.

- Adoptar una actitud crítica frente a las justificaciones de la desigualdad y la discriminación.

- Adoptar una actitud de respeto y tolerancia ante las diferencias.

- Evaluar la formación de prejuicios y estereotipos

\section{CONTENIDOS}

A continuación se especifican los criterios de concreción de los contenidos y su correspondiente justificación desde los contenidos seleccionados para ser trabajados en la U.D. La exposición de dichos criterios se atiene a la normativa vigente, en concreto al Anexo II del Real Decreto 1467/2007, de 9 de noviembre, por el que se establece la estructura del bachillerato y se fijan sus enseñanzas mínimas, el Decreto 416/ 2008, de 22 de julio y el Anexo I de la Orden 5 de agosto de 2008.

a) La dimensión histórica del conocimiento, el contexto en el que se producen los avances y el papel desempeñado por quienes los hicieron posibles.

Este criterio se concreta en la cronología presente en el desarrollo de los contenidos. Empezamos por la consideración del ser humano como un ser en el que confluyen las dimensiones biológica, cultural y racional, para luego explicar su necesidad de los otros para ser reconocido como persona, así como su tendencia natural a vivir en sociedad. Para ello, se sistematizan las teorías de Aristóteles, Hobbes y Rousseau, ofreciendo variadas perspectivas de la problemática a estudiar.

b) La visión interdisciplinar del conocimiento, resaltando las conexiones entre diferentes materias y la aportación de cada una a la comprensión global de los fenómenos estudiados.

La presente U.D. se rige por este criterio en la medida en que sus propios contenidos así lo demanda. En efecto, el diseño de los contenidos ha tenido en cuenta la aportación de la antropología cultural, de la sociología y de la filosofía, lo que otorga a la U.D. el estatus de interdisciplinar, abogando por la conexión con otras materias, en concreto con Ética y ciudadanía donde el alumnado ya ha adquirido ciertos contenidos sobre la sociedad multicultural y que esperan ser ampliados y profundizados. 
c) La aplicación de lo aprendido a las situaciones de la vida cotidiana, favoreciendo las actividades que capaciten para el conocimiento y análisis del medio que nos circunda y de las variadas actividades humanas y modos de vida.

Concretamos este criterio con algunas de las actividades propuestas, las cuáles tienen el propósito de acercar a la vida cotidiana del alumnado las problemáticas tratadas. Asimismo, la propia dinámica intercultural, conlleva que los contenidos seleccionados colaboren en la tarea de apreciar lo diferente, de reflexionar sobre lo otro, y de aprender sobre la diversidad cultural.

d) El aprovechamiento de las diversas fuentes de información, cultura, ocio y estudio presentes en la sociedad del conocimiento.

Este criterio se plasma en las actividades de búsqueda, requeridas por contenidos que presentan una mayor dificultad y que por tanto suponen un trabajo más detallado por parte del alumnado. Para ello, se incentiva el uso de las tecnologías, en concreto de Internet, así como de los recursos disponibles en el centro, como la Biblioteca.

e) La toma de conciencia sobre temas y problemas que afectan a todas las personas en un mundo globalizado, entre los que se considerarán la salud, la pobreza en el mundo, el agotamiento de los recursos naturales, la superpoblación, la contaminación, el calentamiento de la Tierra, la violencia, el racismo, la emigración y la desigualdad entre las personas, pueblos y naciones.

Dedicamos la mayor parte de la U.D. a tratar la desigualdad, el racismo, la emigración, la intolerancia, los estereotipos y prejuicios. Los contenidos seleccionados tienen la finalidad de concientizar al alumnado sobre estas problemáticas que se consideran prioritarias en una sociedad democrática.

f) El análisis de las formas de exclusión social que dificultan la igualdad de los seres humanos, con especial dedicación a la desigualdad de las mujeres.

En concreto, el contenido de prejuicios y estereotipos analiza los mecanismos de exclusión social, mientras que el análisis de las múltiples actitudes ante la diversidad cultural, propone un estudio de las actitudes que no promueven la igualdad de los seres humanos, y que por tanto han de ser identificadas por el alumnado de forma crítica.

g) La adopción de una perspectiva que permita apreciar la contribución de las diferentes sociedades, civilizaciones y culturas al desarrollo de la humanidad, y adquirir la visión continua y global del desarrollo histórico, especialmente referida a los últimos siglos, posibilitando así una interpretación objetiva del devenir de la humanidad.

Hablar de interculturalidad y de diálogo entre las culturas abre el camino de la reflexión y del aprendizaje de las culturas desconocidas, apostando por la inclusión de lo diferente y positivo o enriquecedor que puede aportarnos el conocimiento de otras formas de desarrollo social.

h) El análisis y la valoración de las contribuciones más importantes para el progreso humano en los campos de la salud, el bienestar, las comunicaciones, la difusión del conocimiento, las formas de gobierno y las maneras de satisfacer las necesidades humanas básicas. 
Se ha seleccionado un apartado para desarrollar el relativismo cultural y el universalismo. Ambos contenidos hacen referencia a la importancia de los derechos humanos. Por otra parte, el contenido que versa sobre la aporofobia, pretende que el alumnado valore la sociedad del bienestar y haga un análisis crítico de las necesidades humanas básicas.

i) El conocimiento de los procedimientos y de los temas científicos actuales y de las controversias que suscitan, así como la adquisición de actitudes de curiosidad, antidogmatismo y tolerancia y la conciencia de la necesidad de caminar hacia la sostenibilidad del planeta.

Todos los contenidos propuestos buscan despertar la curiosidad de los alumnos/as captando su interés sobre las cuestiones planteadas. Por otra parte, la actitud antidogmática y la tolerancia son dos imperativos consonantes con la propuesta de trabajo que plantea la U.D. en general.

Los criterios j) y k) son también tenidos en cuenta por esta U.D. y se aplicarán de una manera indirecta en los contenidos y actividades previstos.

I) El desarrollo de la capacidad comunicativa y discursiva en diferentes ámbitos, tanto en lengua española como extranjera, que permita consolidar los aprendizajes realizados por el alumnado en las etapas educativas anteriores y contribuir a su formación integral a través del respeto, el interés y la comunicación con otros hablantes, desarrollando una conciencia intercultural como vehículo para la comprensión de los problemas del mundo globalizado.

Los contenidos que forman parte de la U.D. serán puestos en práctica a través de debates programados así como por medio de las intervenciones del alumnado. El diálogo es una herramienta particularmente filosófica que será puesta en práctica siempre que sea posible y que se considera muy relevante para el desarrollo personal del alumnado. Por lo tanto, se espera contribuir al desarrollo de su capacidad comunicativa, a la mejora de su capacidad de expresión oral y a la consolidación de los aprendizajes previstos.

m) El fomento de la actividad investigadora en el aula como fuente de conocimiento, con objeto de armonizar y conjugar los aprendizajes teóricos con los de carácter empírico y práctico.

Por medio de actividades específicas que se pueden consultar en el desarrollo de las sesiones, se espera contribuir a este criterio, en la medida en que la actividad investigadora ha sido requerida por algunos contenidos que precisan de la misma para ser captados íntegra y correctamente.

\subsection{Elementos de aprendizaje de la U.D.}

A continuación se detallan los contenidos específicos de esta U.D. en términos de conceptos, habilidades, actitudes y valores que el alumnado adquirirá al finalizar la presente U.D. La selección de estos elementos de aprendizaje se ha realizado en consonancia con los criterios de concreción mencionados en al apartado anterior. 


\section{A) Aprendizajes en términos de Conceptos.}

- Diferencia naturaleza-cultura.

- Identidad.

- Socialización

- Cultura

- Multiculturalismo.

- Pluralismo.

- Interculturalismo.

- Eurocentrismo.

- Etnocentrismo.

- Aporofobia.

- Xenofobia.

- Racismo.

- Relativismo cultural.

- Universalismo cultural.

- Tolerancia activa.

- Prejuicio.

- Etnia.

- Estereotipo.

\section{B) Aprendizaje en términos de Habilidades.}

Diferenciación precisa de los conceptos de naturaleza y de cultura.

> Evaluación de la cultura como medio de descubrimiento y desarrollo de nuestras capacidades.

> Adopción de una actitud crítica fundamentada hacia los valores que subyacen a cada cultura, mostrando tolerancia y respeto hacia prácticas y valores distintos de los propios.

$>$ Definición de los términos "xenofobia", "aporofobia", "racismo" e "interculturalidad".

$>$ Detección de las características de nuestra sociedad multicultural.

$>$ Reconocimiento de las actitudes etnocentristas, relativistas e interculturales.

$>$ Respeto y tolerancia crítica ante la diversidad cultural.

$>$ Reconocimiento de las teorías filosóficas que explican la naturaleza social del ser humano.

$>$ Debate en el que se argumente de forma razonada sobre la diversidad cultural.

> Valoración del intento de construir un proyecto cultural universal, en el que puedan ser integradas las aportaciones de las diversas culturas.

$>$ Exponer y expresar de manera argumentativa las propias opiniones.

$>$ Debatir de forma organizada sobre la pluralidad cultural y las diversas actitudes que se pueden adoptar ante ella. 
Leer críticamente textos referentes a la cultura.

\section{C) Aprendizaje en términos de: Actitudes y valores.}

Valorar los intentos de pensar en términos universales

$>$ Tomar conciencia del papel decisivo que juega la cultura en nuestra vida.

$>$ Valorar la necesidad de relación, reconocimiento y convivencia que posee todo ser humano.

$>$ Percatarse de la diversidad cultural.

$>$ Desarrollar una actitud de respeto y tolerancia crítica ante la diversidad cultural.

> Valorar el diálogo como medio de resolución de conflictos.

V Valoración de la diversidad del fenómeno humano, mostrando la apertura y empatía hacia otras formas de culturización propiciadas por diferentes modelos de sociedad.

\subsection{Esquema de Contenidos}

Se propone la siguiente distribución de los contenidos atendiendo a una línea temporal que pretende avanzar desde la peculiaridad del ser humano en tanto ser cultural, pasando por el desarrollo de su identidad personal imbricada con su identidad social, hasta llegar a su necesidad natural de vivir en sociedad y de avanzar hacia la construcción de una sociedad plural y democrática.

De esta manera el esquema de los contenidos (cuyo desarrollo se puede consultar al finalizar la sección de desarrollo de las sesiones) propuestos es el siguiente:

\section{El carácter cultural del ser humano}

\subsection{Animal racional}

\subsection{Convivencia e intersubjetividad}

2. La dimensión social de la vida humana

2.1. ¿El ser humano es un ser social por naturaleza?

\section{Los procesos de socialización}

3.1. Ser persona: identidad personal e identidad social

3.2. El problema de la identidad personal

3.3. La socialización y sus formas

4. La importancia de la cultura

\subsection{Características de la cultura}




\subsection{Subcultura y contracultura}

\section{El reto de la diversidad cultural}

\section{1. ¿Por qué es importante reflexionar sobre la diversidad cultural?}

\subsection{La formación de estereotipos y prejuicios.}

\subsection{El interculturalismo: una apuesta por la integración}

\section{TEMPORALIZACIÓN}

La temporalización ha sido diseñada principalmente bajo dos criterios: flexibilidad y adaptación. Es decir, la previsión que a continuación se detalla será flexible en la medida en que si es necesario incluir otra sesión para especificar un contenido o realizar una actividad que se considera pertinente y que no ha sido programada, se podrá hacer sin dificultad. Y es adaptativa a las circunstancias, grupos de clase y calendario escolar, permitiendo la modificación, sustitución o aplazamiento, en caso de que fuere necesario, de las sesiones programadas.

Por otra parte, los tiempos se han dividido de manera que la actividad teórica, esto es, la exposición por parte del profesorado de los contenidos, y la parte práctica, el análisis de textos, los debates, el visionado de cortometrajes, se combinen de manera equitativa. Así, nos encontramos con sesiones en las que se prioriza el tratamiento de contenidos teóricos, y otras en las que se dedica la sesión por entero a la preparación y puesta en práctica de un debate.

En el apartado Desarrollo de las sesiones, del presente trabajo, se puede encontrar una programación detallada de las sesiones, del tiempo estimativo de las mismas, y de su distribución. Asimismo, se puede constatar el diseño de un Cuaderno de trabajo conformado por múltiples actividades que pretenden suplir la falta de tiempo a la que el profesorado se ve sometido por el calendario escolar.

Además, los criterios en los que se fundamenta la distribución de los contenidos y actividades de esta U.D., son los de tiempo y recursos disponibles, facilidad de transmisión de contenidos, sencillez expositiva, interés por parte del alumnado y eficacia comprobada. En efecto, las nueve sesiones aquí expuestas ya han sido puestas en prácticas y por lo tanto está comprobada su exitosa realización.

A continuación, presentamos una tabla orientativa de la distribución de las sesiones en la que se indican los contenidos, las actividades y los tiempos que se dedicarán a cada uno. El tiempo estimado de duración de la U.D. será de nueve sesiones distribuidas en tres semanas lectivas. 


\begin{tabular}{|c|c|c|}
\hline SESIÓN & CONTENIDO & ACTIVIDAD \\
\hline 1 & $\begin{array}{l}\text { 1. El carácter cultural } \\
\text { del ser humano: } \\
\text { epígrafes } 1.1 \text { y } 1.2 \text {. } \\
\text { [35'] }\end{array}$ & $\begin{array}{l}\text { Resolución de los textos: a) "El hombre y la gente" de J. } \\
\text { Ortega y Gasset y b) "Los orígenes de la civilización" de V. } \\
\text { Gordon [25'] }\end{array}$ \\
\hline 2 & $\begin{array}{l}\text { 2. La dimensión social } \\
\text { del ser humano: } \\
\left.\text { epígrafe } 2.1 .{ }^{20}\right]\end{array}$ & Búsqueda información en Biblioteca del centro [40'] \\
\hline 3 & $\begin{array}{l}\text { 3. Los procesos de } \\
\text { socialización: epígrafes } \\
\text { 3.1 y 3.2. [50'] }\end{array}$ & Visualización del video: "Hume, Shrek y las cebollas"[10'] \\
\hline SESIÓN & CONTENIDO & ACTIVIDAD \\
\hline 4 & $\begin{array}{l}\text { Epígrafe } 3.3 . \\
\text { 4. La importancia de la } \\
\text { cultura: epígrafes } 4.1 \text {. } \\
\text { [35'] }\end{array}$ & $\begin{array}{l}\text { Encuesta sobre preconceptos [10'] } \\
\text { Actividad escrita de refuerzo sobre la socialización[15'] }\end{array}$ \\
\hline 5 & $\begin{array}{l}\text { Epígrafe } 4.2 \text {. } \\
\text { 5. El reto de la } \\
\text { diversidad cultural: } \\
\text { epígrafe } 5.1 .\left[45^{\prime}\right]\end{array}$ & $\begin{array}{l}\text { Actividad oral que versará sobre la clasificación de grupos } \\
\text { en subcultura o contracultura [15'] } \\
\text { - Entrega de los ensayos sobre el experimento } \\
\text { mental. }\end{array}$ \\
\hline 6 & $\begin{array}{l}\text { Continuación del } \\
\text { epígrafe 5.1. [35'] }\end{array}$ & $\begin{array}{l}\text { Debate dirigido sobre el reportaje "Mi vida con el velo" de } \\
\text { A. Concuera [25'] }\end{array}$ \\
\hline SESIÓN & CONTENIDO & ACTIVIDAD \\
\hline 7 & $\begin{array}{c}\text { Epígrafe } 5.2 \text { y } 5.3 . \\
{\left[45^{\prime}\right]}\end{array}$ & Resolución del texto "Aporofobia" de A. Cortina [15'] \\
\hline 8 & $\begin{array}{lrr}\text { Explicación sobre } & \text { el } \\
\text { procedimiento } & \text { y } & \text { las } \\
\text { ventajas } & & \text { del } \\
\text { debate.[10'] } & & \end{array}$ & $\begin{array}{l}\text { Debate sobre el Interculturalismo a partir de una entrevista } \\
\text { realizada por Joan Soler a Alí, un inmigrante magrebí. [50'] } \\
\text { - Entrega de los cuadernos de trabajo. }\end{array}$ \\
\hline 9 & Examen de la U.D. [60'] & \\
\hline
\end{tabular}




\section{COMPETENCIAS BÁSICAS}

Si bien las competencias básicas son exigibles para la Educación Secundaria y no para el Bachillerato, creemos oportuno incluirlas en la medida en que colaboran a orientar la activad docente y fomentan en el alumnado la adquisición de competencias necesarias para el desarrollo de su personalidad y autonomía. En esta unidad se trabaja especialmente el desarrollo de las siguientes competencias básicas:

> Competencia en comunicación lingüística (C1). En esta unidad trabajaremos especialmente esta competencia al definir al ser humano como un ser que se abre a la cultura dada su capacidad comunicativa, herramienta indispensable para la creación del universo simbólico que envuelve toda su actividad. Se desarrolla, además, en los trabajos con textos filosóficos: lectura, interpretación y exposición de los contenidos de dichos textos. Se trata de una unidad basada en la escucha y la réplica, de modo que el ejercicio comunicativo es constante, tanto escrito como oral. También la lectura de textos de un grado de complejidad apropiado ayuda a ampliar dicha competencia. Por último, el conocimiento y el uso de términos y conceptos propios de la Filosofía y otras áreas de conocimiento enriquecen el vocabulario.

Tratamiento de la información y competencia digital (C4). El tratamiento de la información y la competencia digital son asumidos por esta unidad desde el momento en que para materializarse precisa de variadas fuentes de información y variados instrumentos de interacción propios de la sociedad del conocimiento, lo que implica el uso de recursos digitales. Por un lado, aquellos que fomentan la interactividad y el compartir conocimiento; redes digitales horizontales basadas en las herramientas colaborativas de la web 2.0 (blog, wiki, etc.). Por otro, los que hacen posible la selección y el tratamiento adecuado de la información acumulada en Internet a partir de criterios específicos.

$>$ Competencia social y ciudadana (C5). Esta competencia cobra especial relevancia en la asignatura de Filosofía y ciudadanía, en general, y específicamente en el tratamiento de la presente unidad, en la medida en que se trata de una competencia orientada a comprender el mundo en el que vivimos. La dimensión cultural exclusiva del hombre, nos conduce a una dimensión social y cívica propia. Se reflexiona sobre esta peculiaridad humana, y sobre la estrecha vinculación entre cultura y sociabilidad humana. Se insiste pues, en el desarrollo de una visión personal en diálogo con todas las personas, remarcando especialmente unas relaciones de género equitativas, así como en el respeto a los Derechos Humanos. Además, las formas de trabajo colaborativo que favorecen el encuentro entre las individualidades y con ello el surgimiento de lazos sociales, refuerzan la contribución a la adquisición de la competencia.

> Competencia en cultura humanística y artística (C6). La competencia en cultura humanística y artística recibe un impulso en cuanto que la filosofía toma las creaciones culturales y 
artísticas como base para sus reflexiones. La cultura es un referente ineludible para la filosofía en general y en particular para la ciudadanía, estrechamente ligada a la idea de encuentro cultural y a la interculturalidad, y por tanto al respeto hacia culturas y manifestaciones artísticas de otros pueblos.

> Competencia para aprender a aprender (C7). La inteligencia humana es también cultural y está sometida a un proceso de evolución. Este estudio se completa con el trabajo de habilidades de lectura, comprensión e interrelación de documentos e ideas con conceptos ya asimilados en las anteriores unidades y en las materias de Educación para la ciudadanía y los DD.HH. (2ํㅡ.S.O.) y Educación ético-cívica (4으. E.S.O).

Al mismo tiempo, el trabajo colaborativo, junto a la reflexión personal a partir del análisis sistemático y de la argumentación, contribuyen al desarrollo de la competencia para aprender a aprender, puesto que predisponen al alumnado a la utilización rigurosa del pensamiento en un ejercicio de retroalimentación y transferencia hacia otras dimensiones de su actividad diaria que le permiten tomar conciencia de lo que sabe y con ello una idea equilibrada de su competencia personal. Igualmente se potencia la capacidad de autorregulación del aprendizaje, ya que ofrece al alumnado la posibilidad de referirlo a criterios construidos en la confrontación dialógica de los debates y del trabajo colaborativo.

> Competencia para la autonomía e iniciativa personal (C8). Esta unidad también desarrolla la competencia para la autonomía e iniciativa personal, puesto que favorece la toma de posición individual y su defensa dialógica. La exigencia de realizar valoraciones con lo que ello conlleva (contrastar, sopesar, elegir...) y de hacer aportaciones, la insistencia en la argumentación y la elaboración de una visión personal, modelan la autonomía del sujeto fundamentada en la coherencia reflexiva.

$>$ Competencia para aprender a pensar (C9). Esta competencia es especialmente desarrollada en la presente unidad, en la medida en que resulta indispensable realizar la labor de interpretación de la información, para luego poder hacer un uso de la misma. Se trata pues, de favorecer la capacidad de discernimiento, de relación, y de comprensión y valoración del mundo, a través de la lectura de textos y de las actividades propuestas. Mencionar que esta competencia no está recogida en el texto legal: Anexo I del Real Decreto 1631/2006, de 29 de diciembre, pero que sin embargo, ha sido introducida por su pertinencia y a modo de reivindicación de su necesidad.

\section{METODOLOGÍA}

Principios metodológicos generales:

La metodología será activa, dinámica y participativa. Se trata pues, de implicar al alumnado en el proceso de aprendizaje recurriendo a la cercanía del mundo del alumnado. Para lograr tal objetivo, 
se utilizarán ejemplos extraídos de la experiencia cotidiana, así como textos de origen literario o periodístico, además de los estrictamente filosóficos.

Las exposiciones magistrales, o clases de carácter teórico, estarán guiadas por el rigor argumental, para que los alumnos/as puedan aprender a reflexionar y justificar las tesis expuestas y alcancen un aprendizaje significativo. En la misma medida, primará la claridad expositiva, utilizando un lenguaje asequible que, sin embargo, no renunciará a la precisión y a la exigencia de que el alumno se haga con un mínimo de vocabulario específico de esta unidad.

Por otra parte, se persigue la imparcialidad a la hora de exponer los contenidos con ecuanimidad.

Se fomentará la interacción en el aula como motor de aprendizaje, y se inducirán hábitos racionales y prolijos de trabajo en el alumnado. Todo ello, con la finalidad de facilitar el trabajo autónomo del alumnado, favoreciendo la capacidad para aprender por sí mismo (a través de los debates y exposiciones) así como la capacidad para trabajar en equipo (por medio de los trabajos grupales).

\section{Principios metodológicos específicos:}

La unidad se planteará partiendo de preguntas o de actividades motivadoras, lo cual puede provocar un primer debate sobre el asunto. A continuación, el trabajo sobre conceptos teóricos se intercalará con la realización continua de ejercicios y trabajos que el alumnado reflejará en su cuaderno. Una actividad realizable a lo largo de todo el curso puede ser la lectura de artículos o noticias de prensa vinculados a apartados de la unidad.

La práctica del debate y del trabajo en grupos será una parte importante en la metodología, pues la capacidad para relacionarse y cooperar, para escuchar y exponer las propias ideas de forma correcta, y para entender los argumentos de los demás es uno de los objetivos fundamentales que se persiguen con esta unidad.

A continuación se exponen las fases del trabajo a realizar en el transcurso de la U.D.:

$>$ Entrega de un dossier de materiales que incluirá el material que utilizaremos durante las sesiones programadas.

> De introducción-motivación: su finalidad es introducir al alumnado en la temática a tratar captando su interés. Las cuestiones previas, las preguntas de introducción y los videos deberán cumplir este propósito.

$>$ De conocimientos previos: se trata de las encuestas sobre preconceptos que se realizaran como actividad inicial en algunas sesiones, y cuyo objetivo es conocer las ideas, opiniones, conocimientos, del alumnado sobre los contenidos que se van a desarrollar. 
De búsqueda y elaboración de información: el objetivo de estas actividades es que el alumnado aprenda a buscar contenidos filosóficos en páginas web, blog, y otras herramientas, discriminado el material valioso del que no lo es. De esta manera, se persigue que desarrolle un sentido crítico de evaluación de la información. Asimismo, se pretende que el alumnado se familiarice con la consulta de libros en la biblioteca del Instituto y /o Departamento de Filosofía.

$>$ De desarrollo: son aquellas actividades que principalmente han sido programadas para ser realizadas en casa, y cuya finalidad es que el alumno/a conozca y experimente los conceptos, procedimientos y actitudes. Incluyen, lecturas de textos filosóficos, sociológicos y políticos, así como la visualización de presentaciones PowerPoints.

De aplicación y consolidación de conocimientos: se trata de que los alumnos/as apliquen los contenidos aprendidos y contrasten sus ideas previas con las ideas nuevas aprendidas. Una actividad que sirve a tales efectos es la de confección de vocabulario específico y el comentario crítico de texto.

$>$ De síntesis-resumen: son las que facilitan la relación entre los distintos contenidos aprendidos, a la vez que ofrecen una visión holística de los temas a tratar.

$>$ De simulación social o role-playing, y de debate preparado.

$>$ De ampliación o profundización: son las actividades dirigidas al fomento de la participación activa en clase y de la intervención del alumnado. En la misma línea, se prevé la realización de actividades de lectura, tanto de materiales filosóficos como de otros materiales complementarios, que colaborarán a ampliar y completar los contenidos del tema.

$>$ De evaluación: algunas de las anteriores, más las pruebas escritas.

$>$ De recuperación: se programan para los alumnos y alumnas que no han alcanzado las capacidades trabajadas.

\section{RECURSOS}

El desarrollo de la presente Unidad didáctica incluirá diversos tipos de materiales. Atenderé, básicamente, a los siguientes:

- Material convencional: lo constituyen los libros de texto, libros específicos sobre la problemática a tratar, recortes de periódicos, reportajes, además de algunas películas y cortometrajes cuyo objetivo será ilustrar un contenido a explicar. También se utilizarán los materiales filosóficos que posee la Biblioteca del centro y/o del Departamento como lecturas de profundización o ampliación de conocimientos. 
- Recursos impresos: el alumnado recibirá material extra por parte del profesorado. Este material va destinado a suplir las deficiencias de los libros de texto, así como a subsanar las dudas que puedan tener los alumnos/as sobre algún contenido en particular. También deberá crear su propio cuaderno de trabajo donde adjuntará las actividades previstas.

- Material no convencional: se trata de aquellos materiales que hayan creado otros profesores/as en otras áreas y que puedan servir para nuestra U.D. Asimismo, se considerarán aquellos materiales que los alumnos/as deseen aportar -siempre y cuando conciernan a la temática y sean relevantes para la misma- a fin de posibilitar el desarrollo de la creatividad, iniciativa y participación de los alumnos/as.

- Medios audiovisuales: se cuenta con un cañón de proyección que permitirá la reproducción de los PowerPoints, así como para la proyección de los materiales audiovisuales. Además, se hará uso de la pizarra digital.

- Medios informáticos: utilización de internet para recopilar información sobre cualquier tema tratado a lo largo de la U.D. Para ello se hará uso de ordenadores portátiles o de la sala de informática del centro.

- Medios clásicos: La tradicional y versátil pizarra del aula.

\section{ATENCIÓN A LA DIVERSIDAD}

En aras de ofrecer un aprendizaje equitativo para todo el alumnado garantizando la igualdad de oportunidades es necesario contar con las necesidades específicas que se derivan de la individualidad de cada alumno/a. Por ello, el objetivo de las medidas de atención a la diversidad es subsanar las diferencias en ritmos de aprendizaje, de trabajo, de realización de tareas concretas o de las diferencias creadas por los entornos socioeconómicos que puedan afectar la educación del alumnado.

Se intentará superar estas situaciones prestando una especial atención a los alumnos/as que la requieran. Esta atención se concreta en explicaciones adaptadas, actividades y tareas concretas, y por supuesto, en el diálogo con aquellos alumnos/as que lo necesiten. Asimismo, se ponen a disposición del alumnado los recursos del centro (tutoría, departamento de Orientación, etc.). Estas medidas se realizarán, en la medida de lo necesario, en colaboración con el tutor o tutora, el resto del Equipo Educativo y el Departamento de Orientación.

De manera que quedará establecido que los alumnos/as que presenten dificultades de aprendizaje importantes serán atendidos con especial atención en función de su problemática. En caso de ser necesario, se realizará una adaptación curricular específica, atendiendo a las necesidades del alumno/a. Todo ello, sobre los fundamentos recogidos en el Decreto 167/2003, de 17 de junio, por el que se establece la ordenación de la atención educativa al alumnado con necesidades educativas especiales asociadas a condiciones sociales desfavorecidas, y el 2 o Plan Integral para la Inmigración en Andalucía 2006-2009. Además se tendrá en cuenta la normativa de la Orden 25 de julio de 2008 por la que se regula la atención a la diversidad. 
Los mínimos se ajustarán a sus dificultades y se establecerá la coordinación pertinente con el Departamento de orientación. En el caso de alumnos/as con dificultades lingüísticas, se procederá a elaborar un currículo en colaboración con el personal de las ATALs, acorde a lo que dictamina el Extracto de la Orden de 15 de Enero de 2007 por la que se regulan las medidas y actuaciones a desarrollar para la atención a la diversidad del alumnado inmigrante y, especialmente, las Aulas Temporales de Adaptación Lingüística.

En el marco de la legislación vigente, y en colaboración con el resto del Equipo Educativo, el tutor o tutora y el Departamento de Orientación, se establecerán las medidas pertinentes de atención a las "Necesidades Educativas Específicas" que pueda tener distinto tipo de alumnado:

- Alumnado diagnosticado con NEE.

El alumnado con necesidades educativas específicas puede llegar a tener múltiples y variadas dificultades y diagnósticos. La variedad situaciones que podemos encontrarnos en clase puede ser interminable, por lo que no es posible considerar aquí las vías de actuación pertinentes para cada caso. Las NEE diagnosticadas pueden ser de muchos tipos (perceptivas, motoras, psíquicas) y, dentro de cada tipo, de distintas categorías (visual, auditiva, enfermedades degenerativas, secuelas de accidentes, síndromes definidos genéticamente, secuelas de accidentes o enfermedades en el embarazo de la madre, secuelas de drogadicción...). De esta manera, estimamos que lo más oportuno será diseñar un plan de acción para cada alumno/a acorde al tipo de NEE diagnosticada y el grado de la misma.

- Alumnado de origen extranjero.

Como se ha especificado anteriormente, el alumnado extranjero será incluido en el mayor número posible de horas en las clases cotidianas para que su adaptación al grupo escolar y al profesorado sea más rápida. En todo caso, se tendrá en cuenta sus dificultades de carácter lingüístico, su base educativa, el tiempo que lleve en nuestro país y sus dificultades de adaptación a nuestro sistema educativo. Además, el trabajo que se realice con estos alumnos/as se llevará a cabo en coordinación con la tarea educativa que realiza el personal encargado de las ATALs.

- Alumnado superdotado intelectualmente.

Dependiendo del grado de superdotación que presente el alumnado, que puede ser muy diferente y afectar a distintas capacidades intelectuales, según el diagnóstico, se procederá a realizar actividades que incentiven al alumnado, así como a motivar su participación en proyectos del centro destinados a estos alumnos/as. Por otra parte, la aceptación e integración en el grupo puede variar mucho de un caso a otro.

En todos los casos la evaluación del alumnado con NEE será detallada y especificada teniendo en cuenta la singularidad de cada alumno/a, así como sus necesidades específicas. De todas maneras, en el apartado de evaluación se proponen algunas medidas que se podría adoptar. 


\section{EDUCACIÓN EN VALORES}

La educación en valores cívicos y éticos de una sociedad democrática, libre, tolerante, plural, etc., es una de las finalidades prioritarias de la educación, y específicamente de esta unidad. En efecto, se busca inculcar en los alumnos valores que permitan la apertura hacia el diálogo cultural, aceptando la diversidad como un hecho que nos enriquece a todos.

En esta unidad tiene una especial relevancia el desterrar los usos del lenguaje y de pensamientos que manifiesten prejuicios raciales, sexistas, clasistas o que representen cualquier intento de discriminación. De la misma manera, se pretende fomentar el respeto por la realidad multicultural de España.

En el estudio de la prensa y de los video expuestos en clase, analizaremos el uso de la imagen que se nos presenta de los colectivos inmigrantes o pertenecientes a otras culturas, con el objetivo de reflexionar de manera crítica sobre la percepción del mundo que nos ofrecen.

De esta manera, se torna prioritario aprender los valores de respeto, tolerancia, y solidaridad, pilares para lograr una convivencia pacífica en la sociedad.

En el marco de la Ley 17/2007, de 10 de diciembre, de Educación de Andalucía que establece en su artículo 39 la educación en valores, se ha diseñado el cuadro siguiente en el que se establecen algunos valores que se trabajarán en la unidad didáctica propuesta. Este cuadro recoge tres núcleos de la Educación en valores e identifica en qué sesión se promoverá su aprendizaje.

\begin{tabular}{|l|c|c|c|c|c|c|c|c|}
\hline \multirow{2}{*}{ Educación en Valores } & \multicolumn{7}{|c|}{ Sesiones de la Unidad Didáctica } \\
\hline & \multicolumn{1}{|c|}{} & $\mathbf{2}$ & $\mathbf{3}$ & $\mathbf{4}$ & $\mathbf{5}$ & $\mathbf{6}$ & $\mathbf{7}$ & $\mathbf{8}$ \\
\hline $\begin{array}{l}\text { Educación moral } \\
\text { cívica }\end{array}$ & $\checkmark$ & $\checkmark$ & $\checkmark$ & $\checkmark$ & $\checkmark$ & $\checkmark$ & $\checkmark$ & $\checkmark$ \\
\hline Igualdad de sexos & $\checkmark$ & & $\checkmark$ & & $\checkmark$ & $\checkmark$ & $\checkmark$ & $\checkmark$ \\
\hline Educación para la paz & $\checkmark$ & $\checkmark$ & & & $\checkmark$ & $\checkmark$ & $\checkmark$ & $\checkmark$ \\
\hline
\end{tabular}




\section{CRITERIOS DE EVALUACIÓN}

\subsection{Criterios de evaluación generales}

La evaluación atenderá no sólo a la valoración de los aprendizajes cognitivos que se espera que adquieran los alumnos/as sino a todos los ámbitos de la persona, teniendo en cuanta la singularidad de cada alumno/a.

Los criterios de evaluación de la presente U.D. se establecen de modo que proporcionen tanto al alumnado como a la profesora la información necesaria sobre el tipo y grado de aprendizaje con respecto a la adquisición de las capacidades establecidas en los objetivos. Asimismo se tendrán en cuenta los distintos tipos de contenidos (conceptos, procedimientos y actitudes). Se procurará que el alumnado conozca estos criterios.

La evaluación tendrá lugar a lo largo de toda la U.D. y será de modo continuo. Si bien, para que la evaluación sea continuada, se requiere del alumnado la asistencia regular a las clases, así como su participación activa en las mismas.

Los criterios generales a tener en cuenta se especifican a continuación.

Argumentar de modo crítico sobre los conocimientos adquiridos en la Unidad Didáctica, elaborando análisis, síntesis y comentarios pertinentes.

Este criterio persigue constatar si el alumnado es capaz de comprender y reflexionar de forma autónoma sobre las aportaciones más relevantes filosóficas, antropológicas y sociológicas al estudio del ser humano, evitando caer en la repetición mimética, la improvisación, la superficialidad, o el pensamiento a-crítico. Este criterio se podrá comprobar a través de los análisis y comentarios de textos, las disertaciones de carácter filosófico, las pruebas escritas, las exposiciones orales y los ensayos.

Exponer y redactar textos propios con cierto rigor argumentativo, haciendo uso de la terminología específica que se requiera, reflejando la comprensión y reflexión de los problemas abordados, así como el progreso en la formación de un pensamiento autónomo.

Este criterio pretende evaluar si el alumnado es capaz de construir y enriquecer sus propias opiniones trabajando de forma constructiva los contenidos específicos de la Unidad didáctica. Para comprobar este criterio, se evaluarán las actividades de tipo reflexivo, relacional, interpretativo, y de crítica fundamentada, que deberán ser expresadas de forma prolija, clara y coherente, reflejando así un adecuado proceso de asimilación y comprensión. Elementos valiosos para su verificación serán las síntesis de los contenidos estudiados, las respuestas planteadas a los textos filosóficos, la preparación y realización de debates, y las investigaciones individuales y en equipo.

Practicar el diálogo filosófico como forma de aproximación colectiva a la verdad y como proceso interno de adquisición de aprendizajes relevantes para la convivencia y de valores democráticos como el respeto mutuo, la sinceridad, la tolerancia y la igualdad. 
Con este criterio se trata de comprobar en el alumnado el grado de comprensión e interiorización de los mecanismos del diálogo racional, así como de las condiciones necesarias para su correcto desarrollo. Asimismo, se trata de que el alumnado valore el sentido del diálogo, sus ventajas y valor democrático en la práctica real del día a día. La preparación y realización de debates sobre cuestiones que afectan a la vida diaria del alumnado, o polémicas en torno a la sociedad actual, permitirán verificar si los alumnos/as reaccionan correctamente ante opiniones contrarias a la suya, anteponen la argumentación racional a los impulsos, actúan de manera responsable y siguiendo conductas propias de la convivencia pacífica y democrática. En la misma línea, se valorará su rechazo de los comportamientos y actitudes xenófobas, racistas, totalitarias o discriminatorias de cualquier índole.

Obtener información relevante a través de diversas fuentes, incluidos Internet, medios de comunicación, biblioteca, y otros recursos interactivos. El alumnado deberá ser capaz de contrastar la información, sistematizarla y utilizarla críticamente en el análisis de problemas, textos y actividades filosóficas, periodísticas, sociológicas y políticas

Este criterio trata de verificar la capacidad del alumnado para seleccionar y manejar fuentes de informaciones diversas, desde el libro de texto, pasando por los materiales aportados por el profesorado, hasta las nuevas tecnologías. Este criterio se podrá comprobar en aquellas actividades que requieren la búsqueda de información para ampliar, completar o resolver las cuestiones planteadas.

Identificar, reflexionar, analizar y comprender los conflictos latentes y emergentes de las complejas sociedades actuales, sus aspectos positivos y negativos, así como el papel de la filosofía en relación a la búsqueda de la solución de dichos problemas mediante el diálogo y la puesta en común de las propias opiniones en vías de aportar una solución consensuada, manifestando una actitud crítica ante todo intento de justificación de las desigualdades sociales o situaciones de discriminación.

Este criterio persigue verificar la capacidad del alumnado para analizar y comprender los problemas sociales y políticos más relevantes de la sociedad actual (xenofobia, aporofobia, desarraigo, falta de cohesión, debilidad o exacerbación del sentimiento de pertenencia, conflictos relacionados con las diferencias culturales, con las desigualdades socioeconómicas y de sexo, etc.), así como los logros e intentos de solución que ofrecen la reflexión filosófica y los sistemas de participación democrática. Asimismo, se trata de evaluar la actitud que han desarrollado los alumnos y las alumnas ante dichos problemas sociales y políticos. Los debates presentan un mecanismo eficaz de comprobación de este criterio.

\subsection{Criterios de evaluación específicos}

Los criterios de evaluación, que a continuación se relacionan, nos permitirán valorar la evolución del aprendizaje del alumnado. Por otra parte, nos ayudan a subsanar las necesidades detectadas, actuando como referentes para estimar la adecuación de las estrategias didácticas empleadas. 
Analiza la distinción entre naturaleza y cultura como ámbitos que afectan a la consideración filosófica del ser humano.

$>$ Conoce, valora y distingue las distintas formas de aproximarnos a la cultura.

$>$ Analiza críticamente la pertenencia a la propia cultura.

$>$ Comenta textos con contenido cultural.

$>$ Expresa de forma argumentada creencias e ideas sobre la diversidad cultural y las posibles actitudes ante ella.

$>$ Analiza las diferentes perspectivas que se pueden adoptar ante una cultura y la variedad de las culturas humanas.

> Identifica y expresa las principales problemáticas en torno a la sociedad multicultural.

$>$ Comprende el sentido de la diversidad cultural humana.

$>$ Identifica y rechaza toda forma de discriminación. Respeta las diferencias personales y muestra autonomía de criterio.

$>$ Identifica, explica, comenta e interpreta imágenes y videos con contenido discriminatorio.

$>$ Utiliza el diálogo como vía de solución de conflictos.

\subsection{Instrumentos de evaluación}

En concordancia con los criterios de evaluación, se utilizarán una serie de instrumentos para evaluar la consecución de los objetivos planteados. Dichos instrumentos pueden dividirse en primarios y secundarios. Los primarios, hacen referencia a aquellos instrumentos que permitirán evaluar los objetivos nucleares de la U.D., mientras que por secundarios entenderemos aquellos instrumentos que evalúan las actividades de ampliación o profundización. Esta diversificación de instrumentos nos permitirá adoptar una metodología más flexible que logrará abarcar las diversas dimensiones del proceso de aprendizaje, adaptándose a las capacidades y necesidades del alumnado.

Los instrumentos básicos son los siguientes:

Diario de clase: este instrumento permitirá realizar una observación sistemática por parte del profesorado de la asistencia, puntualidad, actitud de trabajo, predisposición, atención y ritmo de trabajo del alumnado en clase. Además se constatará la adquisición de las demás actitudes propuestas en los objetivos estipulados.

Pruebas escritas: serán exámenes que incluirán los contenidos y actividades explicadas durante el desarrollo de la U.D. Se realizará uno por U.D. impartida, y otro examen de recuperación para aquellos alumnos/as que no hayan superado la prueba ordinaria. En los Anexos del presente documento se pueden consultar los modelos de exámenes propuestos. 
Cuaderno de trabajo: este cuaderno tiene la finalidad de evaluar el esfuerzo continuado en la realización de las actividades encomendadas. Se trata de actividades generales que desarrollan aspectos importantes de los contenidos propuestos. En la misma medida, estas actividades tienen la función de desarrollar las habilidades especificadas en la presente U.D. El cuaderno de trabajo incluirá actividades de búsqueda de información, de reflexión, de crítica, etc., y deberá ser entregado en la octava sesión.

Por otra parte, están los instrumentos secundarios que permiten evaluar aspectos como la creatividad, la claridad expositiva, la racionalidad argumentativa, la capacidad de trabajo en grupo, etc. Comprende principalmente las siguientes actividades:

a). Elaboración de disertaciones filosóficas.

b). Realización de esquemas y síntesis.

c). Preparación de debates en clase.

d). Intervenciones orales en las puestas en común organizadas en clase.

e). Realización de un ensayo personal cuya redacción será mínimo de una cara en folio A4, y que el alumno entregará en la fecha establecida.

\subsection{Criterios de calificación}

A continuación, se indican los criterios y mecanismos de calificación que se emplearán para obtener la calificación de cada alumno/a. Se prevé tres modos de llevar a cabo la calificación: en primer lugar, la calificación continua, en segundo lugar, aquella que se aplicará en los casos de recuperación y finalmente, la que se empleará en las situaciones de alumnado con NEE.

\section{A) Criterios para la calificación en modo continuo}

Para aquellos alumnos/as que se atengan al modo continuo de evaluación, es decir, que cumplan con los requisitos que a continuación se mencionan, se aplicarán los criterios de evaluación especificados.

La calificación de la unidad didáctica se llevará a cabo acorde a los siguientes porcentajes:

- Prueba escrita $50 \%$ de la nota.

- Disertaciones filosóficas, intervenciones en clase y Cuaderno de trabajo $40 \%$ de la nota.

- Aspectos actitudinales como el interés por la asignatura, adecuado trabajo en grupo, participación adecuada en el desarrollo de las clases, así como el respeto a los compañeros y al profesor $10 \%$ de la nota.

Importante: para aprobar es necesario obtener un 50\% en cada uno de los subapartados anteriores. 


\section{B) Criterios de calificación para la recuperación de la Unidad Didáctica}

La recuperación de los contenidos de la U.D. en cuestión está dispuesta para aquellos alumnos/as que hayan incumplido alguno de los criterios establecidos anteriormente o hayan obtenido una calificación negativa en la evaluación de la U.D. Por tanto, la recuperación consistirá en la realización de una prueba escrita (un examen extraordinario), similar al realizado en la prueba ordinaria (se puede consultar un modelo de examen de recuperación para la presente U.D. en los Anexos). Habrá dos modalidades:

- Una, para aquellos alumnos/as que hayan suspendido el examen pero que hayan cumplido con las entregas de actividades estipuladas y tengan el Cuaderno de trabajo aprobado, mínimo con un cinco. Estos alumnos/as podrán realizar el examen de recuperación.

- Otra, obligatoria para aquellos alumnos/as que no se hayan atenido a la evaluación de modo continuo, que tengan suspenso el Cuaderno de trabajo o el examen. Se procederá a la realización de otro examen de recuperación y deberán rehacer el Cuaderno de trabajo, en el caso de que sea lo que tienen suspenso. Además, se exigirán entre tres y cinco actividades de refuerzo educativo que estos alumnos/as adjuntarán al Cuaderno de trabajo. Dichas actividades serán seleccionadas acorde las dificultades que el registro de observación del profesorado haya detectado.

En ambos casos, para superar las pruebas mencionadas (tanto el examen como el Cuaderno de trabajo) se necesita una calificación de cinco o superior a cinco.

\section{C) Criterios de calificación para alumnos/as con Necesidades educativas específicas}

El alumnado que requiera una adaptación curricular será evaluado siguiendo los criterios que en la mencionada adaptación se especifiquen. Si bien, podemos establecer algunos mecanismos que pueden estar presentes en cualquier adaptación.

- La calificación del alumnado con NEE se expresará en los mismos términos y utilizará la misma escala que en el Bachillerato.

- Se incluirá una valoración cualitativa del progreso de cada alumno/a respecto a los objetivos propuestos para su adaptación curricular.

- aquellos alumnos/as para los que se haya diseñado una adaptación curricular significativa, se procederá a evaluarlos en función de la consecución o no de los objetivos propuestos en dichas adaptaciones significativas. 


\section{DESARROLLO DE LAS SESIONES}

En este apartado se despliegan las sesiones que han sido programadas acorde a lo estimado en la temporalización de la U.D.

Las sesiones se dividen, principalmente, en dos partes: la primera de ellas tiene una función introductoria en la que se retomarán ideas, conceptos, dudas de clases anteriores; y la segunda parte, tiene como finalidad la exposición de los contenidos y la realización de las actividades previstas. En este apartado también se incluyen las actividades que deberán constituir el Cuaderno de trabajo de cada alumno/a, así como las sesiones en las que se deberán entregar las actividades previstas.

\section{SESIÓN PRIMERA}

\section{A) Secuencia de Trabajo:}

En esta primera sesión se hará entrega de un DOSSIER que incluirá a) las instrucciones de trabajo, b) los contenidos que se explicarán durante las nueve sesiones, c) los textos y ejercicios de la U.D., d) material expositivo sobre las teorías a estudiar y referencias (en libros, diccionarios, páginas web,...).

Trabajo introductorio: comenzaremos realizando una contextualización de la U.D en la que se pondrán en relación con los contenidos vistos en unidades anteriores. De esta manera colaboramos en ofrecer al alumnado una visión global y unitaria del material estudiado. También, se procederá a explicitar que la U.D. pertenece al núcleo temático tercero y que se halla relacionada con el bloque segundo y quinto del plan del curso.

\section{B) Actividades previstas:}

De introducción-motivación: comenzaremos planteando el siguiente interrogante: ¿Qué es lo distintivo del ser humano? Los alumnos/as intervendrán proponiendo definiciones, ideas, conceptos que se irán apuntando en la pizarra. A continuación, aunando todas las propuestas se diseñará una respuesta.

De conocimientos previos: se procederá a responder en clase a las preguntas previas que aparecen en la primera página de los contendidos. De esta forma, podremos saber qué nivel de conocimientos sobre el tema tiene el alumnado y de esta manera dirigiremos las sesiones a superar las deficiencias captadas.

De desarrollo y transmisión de información: para que el alumnado pueda conocer y experimentar los conceptos, aptitudes y procedimientos, se realizará una exposición de los contenidos correspondientes a la Introducción y Apartado 1, epígrafes 1.1. y 1.2.

De aplicación y consolidación de conocimientos: para esta sesión se programan tres actividades, dos de ellas cuya realización se prevé realizar en clase y una para realizar en casa. Mencionar que la 
planificación es flexible, y por ello, si el tiempo de la sesión no permite realizar las dos actividades, se encomendará al alumnado que las realice en su casa y las incluya en el cuaderno de actividades que deberá presentar al final de la U.D.

\section{Actividad № 1}

$\checkmark$ Tiempo estimado: 10 minutos

$\checkmark$ Procedimiento: los alumnos/as deberán responder a las cuestiones planteadas en el texto. Se trata de realizar una reflexión guiada por la profesora en clase.

Ortega y Gasset, J., “El hombre y la gente", en Obras completas, VII.

$\checkmark$ Objetivo: Lectura del texto mencionado que se halla incluido en los contenidos, y mediante el cual se espera que el alumnado reflexione e interiorice la necesidad del Otro que todo ser humano posee.

\section{Actividad № 2}

$\checkmark$ Tiempo estimado: 10 minutos

$\checkmark$ Procedimiento: Esta actividad se resolverá en clase mediante un debate organizado en el que los alumnos/as participarán construyendo de manera conjunta el conocimiento.

"La especie humana no se adapta de manera biológica a ningún ambiente particular. La adaptación se asegura por su aparejamiento extracorporal con instrumentos, ropa, casa, etc. Inventados los instrumentos adecuados, la sociedad humana se adapta a todas las condiciones de vida. El fuego, la ropa, las casas y la dieta apropiada hacen que el hombre soporte el frío ártico o el calor tropical igualmente bien. La cultura material es, pues, principalmente, una respuesta al medio ambiente"

Gordon, V., Los orígenes de la civilización.

$\checkmark$ Objetivo: A través de la lectura de este texto, el alumno/a debe reflexionar sobre el carácter cultural del ser humano, percatándose de que, lo que en los animales es biológico, en el ser humano es cultural. El hombre no necesita transformarse físicamente para adaptarse al entorno, sino que realiza una transformación cultural que le permite acomodarse a otros ámbitos desconocidos. La cultura es, pues, una herramienta distintiva y particular del ser humano.

Cuestiones:

1. Pon un título al texto que contenga la idea principal.

2. El texto hace mención a la cultura material. Busca información sobre la distinción que realizan los antropólogos entre cultura material y cultura mental o espiritual. Explica con tus propias palabras sus significados y propón un ejemplo de cada una.

3. ¿En qué sentido se utiliza la palabra extracorporal en este texto? 


\section{Actividad № 3}

$\checkmark$ Tiempo estimado: 30 minutos

$\checkmark$ Procedimiento: Actividad escrita de refuerzo que el alumnado deberá adjuntar a su cuaderno de trabajo.

\section{"Los casos de vida en estado salvaje"}

A continuación nos referimos a tres casos tomados de la "Sociología" de Maclver y Page:

10. El famoso caso de Kaspar Hauser encierra una particular importancia a causa de que este desdichado joven fue, con toda probabilidad, privado de cualquier clase de contacto con sus semejantes por culpa de ciertas maquinaciones políticas, y, por tanto, su estado, al encontrársele, no podía ser atribuido a un defecto innato de su inteligencia. Cuando, a la edad de diecisiete años, vagaba Hauser por las calles de Nüremberg (en 1828), apenas sabía andar, tenía la mentalidad de un niño y únicamente era capaz de murmurar una o dos frases ininteligibles. Desde el punto de vista sociológico es notable que Kaspar tomara a las cosas inanimadas por seres humanos. Y cuando murió, cinco años más tarde, el examen post mortem demostró que su desarrollo cerebral era inferior a lo normal. El haber privado de la sociedad a Kaspar Hauser fue también la negación de su naturaleza humana misma.

2‥ Uno de los casos más interesantes de vida en estado salvaje ha sido en de dos niñas hindúes que en el año 1920 fueron halladas en una guarida de lobos. Aparentaban las edades de unos ocho y dos años, o algo menos, respectivamente. La más pequeña murió a los pocos meses de su descubrimiento, pero la mayor, a la que pusieron por nombre Kamala, sobrevivió hasta 1929, y se conservan abundantes datos de su convivencia en la sociedad humana. Kamala no presentaba casi ninguno de los aspectos que solemos asociar con el proceder humano. Sabía andar únicamente a gatas, no poseía otro lenguaje que algunos gruñidos lobunos $y$, como cualquier otro animal no domesticado, sentía miedo de los humanos. Posteriormente, y como resultado de la más cuidadosa y evidentemente cariñosa enseñanza, fue adquiriendo algunos hábitos sociales rudimentarios: antes de su muerte había aprendido a pronunciar lentamente algunas palabras sencillas, a comer alimentos humanos, a vestirse y otros semejantes. Este "sentido de la propia personalidad humana" de la niña-lobo, totalmente inexistente al principio, cuando fue encontrada, iba brotando gradualmente. Sin embargo, la aparición de su individualidad dependió totalmente de su condición de miembro de la sociedad humana.

3‥ Más recientemente, los sociólogos y psicólogos han estudiado el caso de Anna, una niña ilegítima norteamericana que fue recluida en una habitación a los seis meses de edad y que permaneció allí, incomunicada, hasta su hallazgo, cinco años más tarde, en el año 1938. Durante su encierro Anna apenas se alimentó con otra cosa que con leche, no recibió una educación normal y no tuvo casi contacto con otros seres. Este extremado y cruel aislamiento socia, que proporcionó a los científicos un caso más "de laboratorio", dejó a la niña con muy pocos de los atributos propios de una edad normal de cinco años. Al ser encontrada, Anna no sabía andar ni hablar y era completamente insensible e indiferente a la gente que la rodeaba. Como en el caso Kamala, Anna respondió al 
cuidadoso tratamiento a que se sometió después de su liberación y quizás a causa de su corta edad y de los limitados contactos que experimentó durante su prisión se "humanizó" mucho más rápidamente que aquéllas antes de su muerte, ocurrida en 1942. El caso de Anna pone una vez más de manifiesto que la naturaleza humana únicamente se desarrolla en el hombre cuando es social, sólo cuando él es uno más de los muchos hombres que participan de una vida común.

$\checkmark$ Objetivo: trabajando este texto, los alumnos/as podrán percatarse de la importancia de la cultura y de la sociedad para que el ser humano pueda desarrollar todas sus potencialidades. Esta actividad, también va encaminada a introducir el tema de la socialización que se verá en el epígrafe posterior.

\section{Cuestiones:}

1. Explica cuáles crees que han sido las consecuencias de la nula o escasa socialización que han padecido los niños de los tres casos expuestos.

2. Confecciona una lista con las características comunes de los tres casos.

3. ¿Cuál caso te parece más representativo de la necesidad del ser humano de vivir en sociedad? Razona tu elección.

\section{SESIÓN SEGUNDA}

\section{A) Secuencia de Trabajo:}

Trabajo introductorio: comenzaremos la sesión realizando una breve recapitulación de lo visto en la clase anterior y contestando a las dudas. A continuación se procederá a contextualizar la temática que vamos a abordar. Se trata del Apartado 2, epígrafe 2.1. en el que se exponen las teorías de Aristóteles, Hobbes y Rousseau sobre la génesis social del ser humano.

\section{B) Actividades previstas:}

De introducción-motivación: para entrar en los contenidos, se plantearán los siguientes interrogantes: ¿vivimos con otros individuos porque nuestra naturaleza nos lo exige? ¿ $O$ es una mera casualidad?; Asimismo, este ejercicio nos permitirá introducir el eje central en torno al cual se erigen las propuestas de los autores citados.

De búsqueda y elaboración de información: realizaremos una búsqueda en internet de páginas web o haremos una visita a la biblioteca del Instituto y /o Departamento de Filosofía, para recopilar información básica sobre los tres autores que vamos a ver (Aristóteles, Hobbes y Rousseau), para que el alumno se familiarice con ellos y con su contexto social.

De síntesis-resumen: Los alumnos/as deberán entregar un esquema que contenga la información encontrada. 
De ampliación o profundización: el alumnado confeccionará un cuadro comparativo entre las tres posiciones expuestas en clase, y adjuntará esta tarea, que deberá hacer en casa, a su cuaderno de trabajo.

\section{SESIÓN TERCERA}

\section{A) Secuencia de Trabajo:}

Trabajo introductorio: Recapitulación de los conceptos/ideas más importantes de la clase anterior y resolución de dificultades planteadas por el alumnado.

\section{B) Actividades previstas:}

De introducción-motivación: para suscitar el interés del alumnado, empezaré planteando el hecho de que la experiencia de la identidad individual o personal, hace referencia a un sentimiento de unicidad y exclusividad, que va acompañado de una sensación de permanencia y continuidad a lo largo del tiempo, del espacio y de las diferentes situaciones sociales. A continuación, se planeará el siguiente interrogante: Pero, ¿en qué consiste la identidad personal? ¿Qué hace que tú seas tú?
1. ¿Tu nombre?
2. ¿Tu cara?
3. ¿Tu ropa?
4. ¿Tu mente?
5. ¿Tus pensamientos?
6. Si por algún motivo no pudieras utilizar tu mente, ¿seguirías siendo tú mismo?
7. ¿Eres la misma persona que hace diez años?

8. Si cuando eras pequeñito te hubieran llevado a otro país de modo que crecieras hablando un idioma completamente diferente, ¿̇seguirías siendo tú mismo?

De desarrollo y transmisión de información: se procederá a explicar la teoría humeana del yo, en la medida en que resulta un enfoque clásico de la identidad personal, y, por otra parte, se hará una breve exposición de la teoría del Doctor Ramachandran sobre las neuronas espejo y su concepción de la identidad personal, que se fundamenta en las ideas humeanas. De esta manera, el alumno/a podrá tener una visión filosófica y científica sobre la problemática que abordamos. El seguimiento de la clase se hará a través de los PowerPoints que se incluyen en los Anexos y del material redactado en los contendidos, específicamente el Apartado 3 y los epígrafes 3.1 y 3.2 .

De ampliación o profundización: Visualización del video "Hume, Shrek y las cebollas" donde se realiza una crítica a la idea humeana de "yo".

De evaluación: Realización de un ensayo sobre el planteamiento de John Searle y la máquina teletransportadora de sujetos. Lo que se espera de los alumnos/as es que elijan una de las opciones que plantea el texto y diseñen argumentos para apoyarla o refutarla. El ensayo que realicen deberá ser entregado en la sesión quinta y será objeto de evaluación. El texto propuesto es el que se añade a continuación: 


\section{El problema de la identidad personal. Experimento mental}

Estamos en el siglo XXIV y ya tenemos la suficiente tecnología para realizar la teletransportación a escala humana. Pensemos en una máquina como la siguiente: por un lado tenemos un cañón-lector que se encargaría de leer una a una la posición de todos y cada uno de los átomos de la persona a la que queremos teletransportar. Para hacer esto necesitaríamos, claro está, un supercomputador que ríanse ustedes de éste. A la vez que va leyendo, el cañón-lector va desintegrando uno por uno todos y cada uno de los átomos de la persona a teletransportar.

Después, toda la información almacenada se transmite por cualquier medio de transmisión de información a distancia que se haya inventado en el siglo XXI a un cañón-reproductor, el cual volvería a reconstruir átomo a átomo a nuestro televiajero. Del mismo modo, el cañón-reproductor dispondría de un almacén de materia, donde estarían los átomos necesarios para construir a un ser humano exactamente igual al que está al otro lado del cañón-lector. La cuestión es: ¿La persona reproducida por el cañón-reproductor sería la misma que la desintegrada por el cañón-lector? ¿O quizá habríamos matado a una y generado a otra completamente nueva que no tiene nada que ver con la anterior a pesar de parecerse mucho? ¿Nos fiaríamos de viajar en este novedoso medio de transporte?

La cuestión es difícil y depende de cómo definamos qué es un individuo tendremos una u otra respuesta. Por un lado, si pensamos que el sujeto es mera información independientemente del sustrato que la albergue tal y como piensan muchos pensadores de la Al (Inteligencia Artificial), la respuesta sería que no pasa nada, el individuo es el mismo ya que el nuevo sujeto contiene exactamente la misma información que el viejo, de modo que el teletransportador es plenamente fiable y seguro. Pero por otro, si pensamos que el sujeto no es independiente de la materia de la que está hecho, el viejo sujeto habría sido asesinado ya que el nuevo está hecho de una materia completamente diferente. $Y$, en tercer lugar, si pensamos que el individuo es algo más que materia e información, con toda evidencia, también habríamos matado al viejo sujeto, ya que no sabríamos reproducir ese "algo más" que lo constituye.

El segundo caso (pensar que la materia sí importa) podría solucionarse si nuestro cañón-lector no destruyera la materia, sino que, mediante un "supercable", transportara todos los átomos del viejo individuo al nuevo. Sin embargo, el problema puede retorcerse un poquito más haciéndose más interesante: pensemos que el cañón-reproductor no sólo puede reproducir una copia del sujeto a teletransportar, sino que puede realizar varias. Teóricamente no hay problema: dispone de toda la información y en su almacén de átomos hay más que suficientes. Supongamos que yo soy la atrevida viajera y que se realizan siete copias de mí misma... Habría siete Érikas al otro lado del cañónreproductor. La pregunta ahora se vuelve mucho más inquietante... ¿Quién de esas siete soy yo?

1) Reflexiona sobre las diversas posibilidades que aparecen en el texto y defiende una de ellas con tus propios argumentos. (Extensión: mínimo una cara).

2) Cuestiones guías: ¿Serás una persona durante la teletransportación? ¿Seguirás siendo la misma persona después de la teletransportación? 


\section{SESIÓN CUARTA}

\section{A) Secuencia de Trabajo:}

Trabajo introductorio: realizaremos una encuesta sobre preconceptos, interrogando a los alumnos sobre las siguientes cuestiones:

10.- ¿Qué significa para ti la palabra sociedad?

20.- ¿Crees que los demás esperan que actuemos de determinada manera en determinadas situaciones, por ejemplo: al comer, al conducir un vehículo, al andar por la calle, el ir al cine, etc.?

3‥- ¿Qué influencia tiene la familia sobre la forma de ser de cada uno?

4 .- ¿Qué influencia tiene la escuela, el instituto y la universidad en nuestra forma de ser? ¿Es más o menos importante su influencia que la de la familia?

50.- ¿Crees que los avances tecnológicos (como los móviles, la televisión, los ordenadores, etc.) producen algún cambio en la sociedad?

6‥- ¿Por qué cada categoría social (como los jóvenes, las mujeres, los empleados de banca, etc.) tiene una forma característica de vestir? ¿Has reflexionado alguna vez sobre el sentido de la "moda"?

\section{B) Actividades previstas:}

De introducción-motivación: Comenzaremos captando la atención del alumnado exponiendo la las ideas de Tzvetan Todorov sobre la necesidad de reconocimiento del ser humano. El tema del reconocimiento es muy importante. Todorov, un filósofo búlgaro que todavía vive, afirma que existir es preferible a vivir. Existir es una necesidad infinita (no nos bastarían mil vidas para satisfacer la necesidad de existir) pero podemos saciar esa necesidad parcialmente mediante el reconocimiento de los otros. De manera que la necesidad de existir va de la mano de la necesidad de reconocimiento. Porque me relaciono con el otro y en su mirada me reconozco, existo.

De desarrollo y transmisión de información: explicación del epígrafe 3.3., del Apartado 4 y el epígrafe 4.1., utilizando el PowerPoint que se adjunta en el Anexo.

De síntesis-resumen: el alumnado realizará una síntesis de las características del ser humano en tanto animal cultural, utilizando el material proyectado en clase, así como aquellos elementos que ya han sido tratados en las unidades anteriores y que puedan servirle para integrarlo en su resumen. Esta actividad se adjuntará al cuaderno de trabajo.

De ampliación o profundización: se prevé la realización de la siguiente actividad.

\section{Actividad №1}

$\checkmark$ Tiempo estimado: 15 minutos

$\checkmark$ Procedimiento: Actividad escrita de refuerzo que el alumnado deberá adjuntar a su cuaderno de trabajo. 
$\checkmark$ Objetivo: con esta actividad el objetivo que se persigue es el de la reflexión crítica sobre la propia sociedad, describiendo el papel que tienen los medios de comunicación en tanto agentes de socialización, indagando la realidad adaptativa a la que se someten los inmigrantes y relatando una opinión personal. De esta manera, se espera que el alumnado pueda reflejar los aspectos positivos de nuestra sociedad y cultura (organización democrática, igualdad de oportunidades, beneficios...) y aquellos aspectos rechazables (individualismo, consumismo, competitividad, prejuicios...).

\section{Cuestiones:}

1. Escribe un ejemplo de cada tipo de socialización.

2. Enumera los agentes de socialización que aparecen en la socialización secundaria.

3. ¿Qué tipo de socialización viven los inmigrantes?

4. ¿Crees que los medios de comunicación influyen en nuestra socialización? ¿Qué medio destacarías? ¿Por qué?

5. ¿Qué aspectos de nuestra cultura consideras positivos y cuales negativos?

\section{SESIÓN QUINTA}

\section{A) Secuencia de Trabajo:}

Trabajo introductorio: Entrega de los ensayos sobre el experimento mental. Dichos ensayos serán corregidos con comentarios individualizados para cada alumno/a y devueltos con la posibilidad de volver a rehacer la tarea.

Trabajo de recapitulación: se recordará a los alumnos/as sobre las actividades pendientes y se realizará una revisión del cuaderno de trabajo.

\section{B) Actividades previstas:}

De introducción-motivación: comenzaremos la sesión escuchando la canción "El reino de lo absurdo" de Nach, utilizando este recurso audiovisual como un ejemplo de grupo de crítica social (tribu urbana y alternativo). El alumnado tomará nota de las ideas principales de la canción para luego hacer una puesta en común. (La letra de la canción se puede consultar en los Anexos).

De desarrollo y transmisión de información: explicación del epígrafe 4.2. y del Apartado 5 y epígrafe 5.1., empleando los contenidos y un PowerPoint.

De ampliación o profundización: para ejemplificar los tipos de contracultura realizaremos la siguiente actividad.

\section{Actividad №1}

$\checkmark \quad$ Tiempo estimado: 10 minutos

$\checkmark$ Procedimiento: Actividad oral que se llevará a cabo en clase. 
$\checkmark$ Objetivo: incitar a los alumnos/as a pensar sobre casos reales a los que aplicar la información teórica transmitida. Se propone, en el caso de los grupos alternativos, exponer brevemente el caso de los Amish, y resolver las preguntas que vienen planteadas en los contendidos. A continuación, debatiremos sobre cómo clasificar los grupos que se plantean a continuación, de esta manera, podremos saber si el alumnado ha comprendido correctamente la explicación.

\section{Cuestiones:}

1. ¿Crees que los Amish podrían ser calificados como contracultura o como subcultura? ¿Por qué?

2. Clasifica los siguientes grupos argumentando en cada caso tu elección:

-Comunidad judía de Zaragoza

-Poblado de gitanos a las afueras de Granada

- Asociación filatélica de Murcia

-Grupo de acción ecologista.

\section{Actividad № 2}

$\checkmark \quad$ Tiempo estimado: 30 minutos

$\checkmark \quad$ Procedimiento: Actividad para realizar en casa. Deberá ser adjuntada al cuaderno de trabajo.

$\checkmark$ Objetivo: la finalidad de esta actividad es que el alumno/a se enfrente a un texto científico y pueda extraer de él las ideas más importantes. El contenido del texto propuesto, le permitirá reflexionar sobre la problemática del racismo, a la vez que se familiariza con datos de enorme interés.

Material:

\section{LA GENÉTICA DESCALIFICA EL CONCEPTO DE RAZA}

NATALIE ANGIER (NYT), NUEVA YORK (13-09-00)

(El texto ha sido incluido en los Anexos)

\section{SESIÓN SEXTA}

\section{A) Secuencia de Trabajo:}

Trabajo introductorio: comenzaremos haciendo un ejercicio de recapitulación de conceptos. La finalidad de este ejercicio es que el alumno/a asimile e interiorice la terminología que va apareciendo. 


\section{B) Actividades previstas:}

De introducción-motivación: Comenzamos respondiendo a la siguiente cuestión: ¿Por qué es importante reflexionar sobre la diversidad cultural? Así, retomaremos las ideas expuestas en la clase anterior y daremos un marco de reflexión a la temática intercultural.

A continuación, realizaremos un experimento mental, en que los alumnos/as se situarán. Se trata del planteamiento de John Rawls sobre "el velo de la ignorancia", el cual nos sitúa en una posición original y ofrece un modelo de una situación de elección justa, permitiéndonos plantear la siguiente cuestión: ¿Cómo querrías que estuviera diseñada la sociedad?

De desarrollo y transmisión de información: continuamos con el epígrafe 5.1. y dedicaremos toda la clase a trabajar los conceptos-ideas que allí se plantean.

De ampliación o profundización: se prevé la realización de tres actividades. La primera de ellas, versará sobre una lectura que ofrece una visión periodística sobre el uso del Hijab. Se ofrecerá la posibilidad de visualizar un video, y otros artículos de referencia que pueden consultarse en los Anexos. La segunda actividad tiene como objetivo, reforzar los conocimientos adquiridos por el alumnado. Finalmente, la tercera actividad propone reflexionar sobre el etnocentrismo a través de la visualización del cortometraje Binta y la gran idea. Este video, nos permite pensar sobre cómo nos ven a nosotros desde otras culturas, y a la vez que nos muestra la cultura senegalesa.

\section{Actividad № 1}

$\checkmark$ Tiempo estimado: 20 minutos.

$\checkmark$ Procedimiento:

1. En grupos de cuatro a seis personas leen el reportaje titulado Mi vida con el velo de Álvaro Corcuera.

2. Identifican las ideas principales del texto y las comentan.

3. Eligen una de las ideas analizadas y comentadas en grupo y la exponen al resto del curso, defendiéndola con los argumentos que el grupo considera importantes.

Debate sobre el reportaje: preguntas propuestas:

1. ¿Crees que el velo es una seña de identidad cultural?

2. ¿Qué esconde la problemática en torno a su uso en España?

3. ¿Se debe permitir en los centros educativos que se muestren las pertenencias étnicas de cada alumno/a?

4. ¿Debe existir algún límite para ello? ¿Qué beneficios podrían obtenerse de tales muestras de identidad y qué perjuicios?

\section{Actividad № 2}

$\checkmark$ Tiempo estimado: 20 minutos.

$\checkmark$ Procedimiento: Actividad para realizar en casa e incluir en el cuaderno de trabajo. 


\section{Cuestiones:}

Completa la tabla añadiendo casos concretos que ejemplifiquen a cada una de las posturas siguientes:

\begin{tabular}{|c|c|c|c|c|c|}
\hline Etnocentrismo & Racismo & Xenofobia & Relativismo & Universalismo & Interculturalismo \\
\hline $\begin{array}{l}\text { Considera que } \\
\text { la música } \\
\text { flamenca es } \\
\text { mejor que } \\
\text { cualquier otra. }\end{array}$ & $\begin{array}{l}\text { Creer que las } \\
\text { personas } \\
\text { negras no } \\
\text { merecen las } \\
\text { mismas } \\
\text { oportunidades } \\
\text { que las blancas. }\end{array}$ & $\begin{array}{l}\text { Sentir rechazo } \\
\text { a los } \\
\text { extranjeros } \\
\text { que vienen a } \\
\text { buscar trabajo }\end{array}$ & $\begin{array}{l}\text { Defender que } \\
\text { no se puede } \\
\text { criticar la } \\
\text { discriminación } \\
\text { que sufre la } \\
\text { mujer en otras } \\
\text { culturas. }\end{array}$ & $\begin{array}{l}\text { Creer que el } \\
\text { gusto por el } \\
\text { arte es común a } \\
\text { todas las } \\
\text { culturas } \\
\text { existentes }\end{array}$ & $\begin{array}{l}\text { Conocer y respetar } \\
\text { las distintas } \\
\text { tradiciones } \\
\text { gastronómicas. }\end{array}$ \\
\hline
\end{tabular}

1. De estas actitudes sobre la diversidad cultural, ¿̇cuáles crees que están más extendidas en nuestra sociedad? Reflexiona tu respuesta.

\section{Actividad № 3}

$\checkmark$ Tiempo estimado: 1 hora.

$\checkmark$ Procedimiento: Visionado del cortometraje "Binta y la gran idea" (30 minutos). Actividad para realizar en casa y adjuntar en el cuaderno de trabajo.

Adjunto la carta que el protagonista lee al final del cortometraje, dado que contiene las ideas principales y guía del video.

\section{La gran idea}

Me he enterado gracias a mi amigo Souleyman de los asombrosos acontecimientos que suceden en el mundo de los tubab. Me estoy refiriendo, por ejemplo, a los grandes ingenios que les permiten extraer el máximo de lo que la tierra nos ofrece. Por lo visto los tubab, gracias a la increíble cantidad de peces que son capaces de coger, obtienen tantos beneficios que ya no necesitan preocuparse los unos de los otros. Por todo ello, y comprendiendo que si seguimos el camino que el primer mundo nos marca, corremos el riesgo de que los hijos de nuestros hijos se queden sin peces, sin árboles, sin aire, que el afán de acumular bienes nos lleve a perder el sentimiento de solidaridad, y que el miedo a perder las riquezas acumuladas nos lleve a destruirnos entre nosotros. Por todo esto me veo en la obligación de aportar mi pequeño grano de arena y hacer algo por evitar el desastre. Es por esta razón que solicito iniciar los trámites de adopción de un niño tubab, ya destetado a ser posible, para que pueda aquí desarrollarse como persona y adquirir los conocimientos necesarios para ser feliz en nuestra humilde comunidad. Así este niño, cuando sea hombre, podrá contribuir al progreso de la humanidad, que tanto nos preocupa a todos nosotros. 
Cuestiones:

1. ¿Cuáles crees que son los rasgos característicos de la cultura española? ¿Y de la senegalesa?

2. ¿Qué diferentes culturas conocemos a nuestro alrededor?

3. ¿Todas las personas de un mismo país comparten una misma cultura?

4. ¿Una cultura es homogénea? ¿Cambian las culturas? ¿Cómo evolucionan? ¿Qué papel juegan el intercambio y las nuevas generaciones? ¿Es bueno que se mezclen las culturas?

5. ¿De qué sirve a Souleyman el reloj suizo? ¿Qué es el progreso para nosotros? ¿Hay una única idea de progreso?

6. ¿Existe discriminación de género en nuestra cultura? ¿Hay tradiciones que nos gustaría cambiar? ¿Podemos hacerlo?

Para tratar este tema es interesante recordar la frase que dice uno de los personajes de la película: "¿Quién te ha dicho que en África la mujer se queda en casa? ¿Dónde lo pone? iEse no es el África que nosotros queremos!".

7. Completa la tabla que se expone a continuación.

\begin{tabular}{|c|c|c|}
\hline PALABRA & DEFINICIÓN & EJEMPLO \\
\hline Cultura & $\begin{array}{l}\text { Conjunto de modos de vida y } \\
\text { costumbres, conocimientos y grado } \\
\text { de desarrollo artístico, científico, } \\
\text { industrial, en una } \\
\text { época, grupo social, etc. }\end{array}$ & \\
\hline Tradición & $\begin{array}{l}\text { Transmisión de noticias, } \\
\text { composiciones literarias, doctrinas, } \\
\text { ritos, costumbres, etc., hecha de } \\
\text { generación en generación. }\end{array}$ & \\
\hline Convivencia & $\begin{array}{l}\text { Acto de vivir en compañía de otro u } \\
\text { otros }\end{array}$ & \\
\hline Interculturalidad & $\begin{array}{l}\text { Relación entre varias culturas dentro } \\
\text { de un mismo entorno, que supone } \\
\text { interacción comunicativa, } \\
\text { comprensión, y } \\
\text { aprendizaje y beneficio mutuos }\end{array}$ & \\
\hline
\end{tabular}




\section{SESIÓN SÉPTIMA}

\section{A) Secuencia de Trabajo:}

Trabajo introductorio: comenzaremos resolviendo las dudas que hayan podido quedar pendientes de la clase anterior. Asimismo, se recapitularán las ideas más importantes explicadas durante las sesiones anteriores.

\section{B) Actividades previstas:}

De introducción-motivación: durante esta sesión se procederá a explicar los epígrafes 5.2. y 5.3., los cuales se hallan desarrollados en los contenidos.

De ampliación o profundización: realizaremos dos actividades encaminadas a consolidar los contenidos vistos durante las clases.

\section{Actividad № 1}

$\checkmark$ Tiempo estimado: 10 minutos.

$\checkmark$ Procedimiento: los alumnos/as se colocarán en parejas y leerán el Artículo de Adela Cortina que se incluye en los contenidos. A continuación responderán por escrito a las cuestiones que se plantean, para luego exponerlas en clase.

$\checkmark$ Objetivo: la intención de esta actividad es que el alumno/a reflexione sobre la actitud discriminatoria que supone la aporofobia, y que a la vez que interioriza el tema, pueda percatarse, a través de los ejemplos que ofrece la autora, de que la aporofobia es una actitud frecuente en nuestra sociedad.

\section{Cuestiones:}

1. ¿Qué significa aporofobia? Investiga su etimología.

2. ¿Qué problemas podemos explicar basándonos en la aporofobia?

3. ¿Crees que existe alguna conexión entre la aporofobia y los prejuicios?

\section{Actividad № 1}

$\checkmark$ Tiempo estimado: 10 minutos.

$\checkmark$ Procedimiento: Cada alumno/a visualizará las siguientes fotografías que serán proyectadas en clase, y deberá responder a las cuestiones que se plantean para después compartirlas en clase.

$\checkmark$ Objetivo: que el alumnado comprenda los mecanismos por los que se rigen la creación de prejuicios, etiquetas y estereotipos. Asimismo, se propone un acercamiento a un fenómeno histórico y socialmente habitual en nuestras sociedades: el problema de la inmigración. 

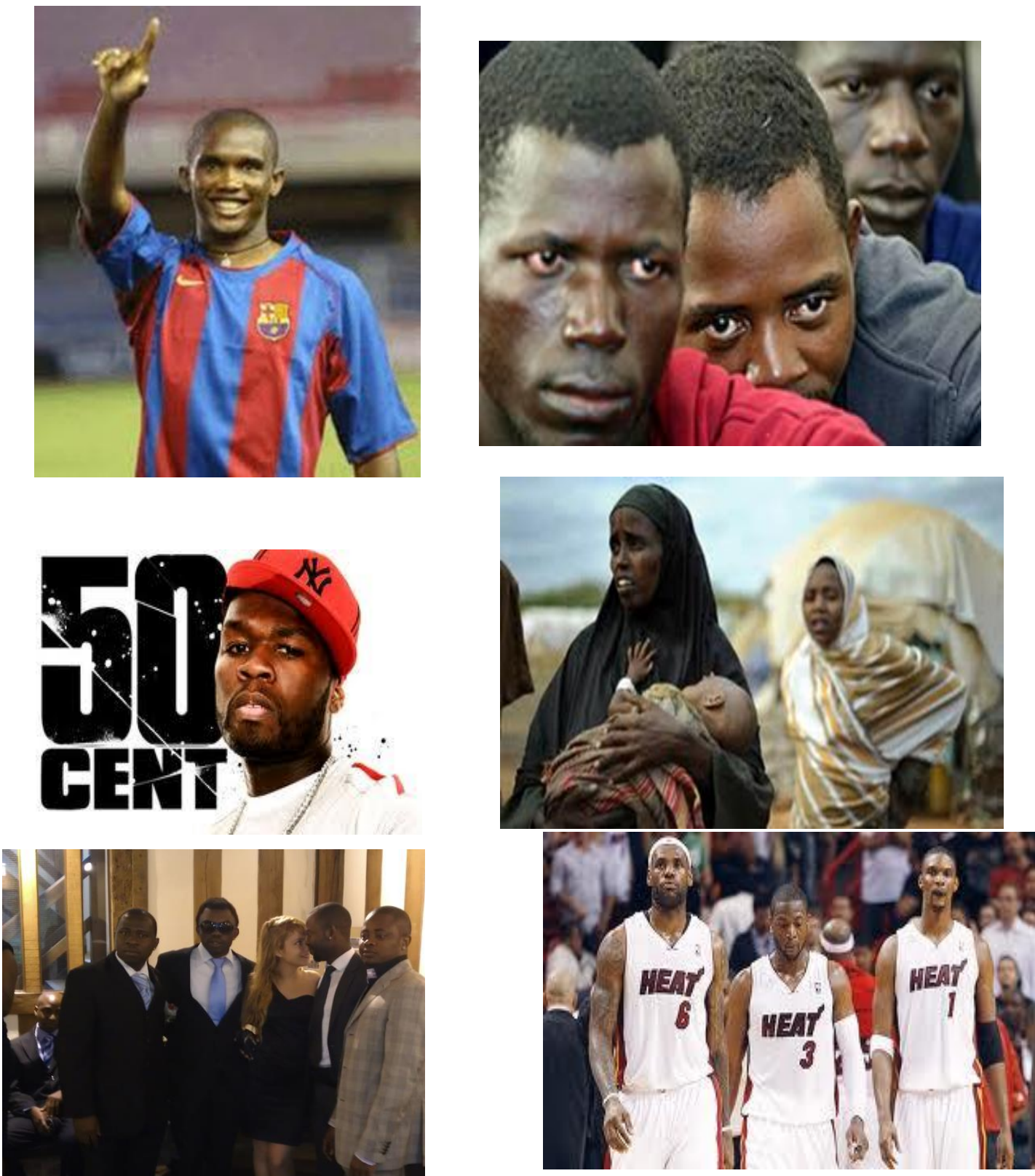

Cuestiones:

1. Analiza las fotografías y explica qué ves en cada una.

2. ¿Crees que el racismo es una cuestión de dinero? ¿Puede tener alguna relación con la aporofobia?

3. ¿Cómo trasmiten los medios de comunicación las noticias sobre los inmigrantes?

4. Realiza una valoración crítica acerca de tus propias respuestas. 


\section{SESIÓN OCTAVA}

\section{A) Secuencia de Trabajo:}

Trabajo introductorio: los alumnos/as entregarán su cuaderno de trabajo debidamente cumplimentado con todas las actividades que se han especificado en las sesiones anteriores y que aquí de detallan:

El Cuaderno de trabajo deberá incluir las siguientes actividades:

- Los casos de vida en estado salvaje.

- Cuadro comparativo de las teorías de Aristóteles, Hobbes y Rousseau.

- Ensayo sobre la máquina teletransportadora.

- Trabajo sobre la socialización.

- La genética descalifica el concepto de raza.

- Tabla de actitudes hacia la diversidad cultural.

- Binta y la gran idea.

\section{B) Actividades previstas:}

De introducción-motivación: comenzaremos explicando la dinámica del debate. Sobre todo, la finalidad del debate es estimular y fomentar actitudes y procedimientos, como: el razonamiento, el análisis crítico, el diálogo, el respeto, la comunicación, la escucha del otro, la tolerancia.

De debate: Leeremos un fragmento de una entrevista realizada por Joan Soler a Alí, un inmigrante magrebí (el texto puede consultarse en los anexos).

\section{Preparación del debate}

Fase de aproximación al tema

- Dividir la clase en dos grupos que trabajaran en primer lugar, de manera separada. Cada grupo escuchará la opinión personal de sus integrantes respecto a las siguientes cuestiones guía:

- ¿Es posible el entendimiento con otras personas de culturas muy diferentes a las nuestras?

- ¿Es positiva la mezcla de culturas?

- ¿Es necesaria la inmigración para que los países europeos puedan desarrollarse?

- ¿Es compatible la pretensión de universalidad de los derechos humanos con la diversidad cultural? 
Fase de desarrollo del plan

- Cada grupo deberá realizar un plan de intervención, redactando las ideas más importantes y otras de carácter secundario que refuercen a las principales.

- Escribir en un folio la presentación que se hará con el orden de los argumentos a exponer.

- Se eligen 5 representantes por cada grupo. A partir de ese momento, el resto de alumnos/as actúan de público, si bien, podrán intervenir si el moderador (el profesor) les da la palabra.

\section{El debate}

-Presentación: Cada representante expone su postura.

-Réplicas y contrarréplicas: el moderador da la palabra alternativamente a los componentes de ambos grupos.

-Deliberación: cada equipo realiza una última intervención en la que resumirá su postura y la justificará.

-Cierre: un miembro de cada grupo expone la conclusión a la que han llegado.

\section{SESIÓN NOVENA}

\section{A) Secuencia de Trabajo:}

Trabajo introductorio: comenzaremos la clase explicando el examen. En los anexos se incluyen tres tipos de posibles exámenes para esta unidad, así como un examen de recuperación para aquellos alumnos/as que no hayan superados los mínimos que la evaluación continua exige, tal y como ha sido reflejado en el apartado de la Evaluación.

\section{B) Actividades previstas:}

Realización del examen. 


\subsection{DESARROLLO DE LOS CONTENDIDOS}

\section{INTRODUCCIÓN}

\section{CONTENIROS;}

\section{1, El carácter cultural del ser humano}

2, La dimensión social de la vida humana

\section{3, Los procesos de socialización}

4. La importancia de la cultura

\section{5, El reto de la diversidad cultural}

\section{CUESTIONES INICIALES}

¿Crees que el ser humano es social por naturaleza?

¿A qué nos referimos cuando decimos de alguien que es inculto?

¿Sabes lo que significa socialización?

¿Por qué existen diversas culturas?

¿Tienes prejuicios sobre algo o alguien en particular?

¿Crees que el diálogo es un buen mecanismo de comunicación?
En esta unidad temática reflexionaremos sobre la dimensión social de la vida humana. Y para ello, comenzaremos indagando sobre la identidad personal, para luego relacionarla con la identidad social y con la naturaleza cultural del ser humano. La filosofía nos habla del ser humano permitiéndonos comprender su complejidad, más allá del discurso biológico.

Los seres humanos necesitamos vivir en sociedad, convivir con los otros, para así poder completarse a sí mismo. $\mathrm{Y}$, en la misma medida, necesita de la cultura para relacionarse, cooperar, decir, orientarse y almacenar sus conocimientos. Así, la cultura se presenta como la segunda naturaleza de los seres humanos.

La dimensión social del ser humano es un hecho incontrovertible. Debido a esta naturaleza social que tenemos todas las personas, existen muchas sociedades y culturas. Esto nos lleva a plantearnos si hay algo que todas las culturas tengan en común (universalismo), o si no es posible compararlas

entre sí (relativismo). El debate sobre el interculturalismo, sobre la convivencia de las distintas culturas en un mismo territorio común, es un debate vivo y obligado, puesto que reflexionar sobre este hecho puede ayudarnos a entendernos mejor a nosotros mismos, a la vez que aprendemos a captar la diversidad como una fuente de riqueza.
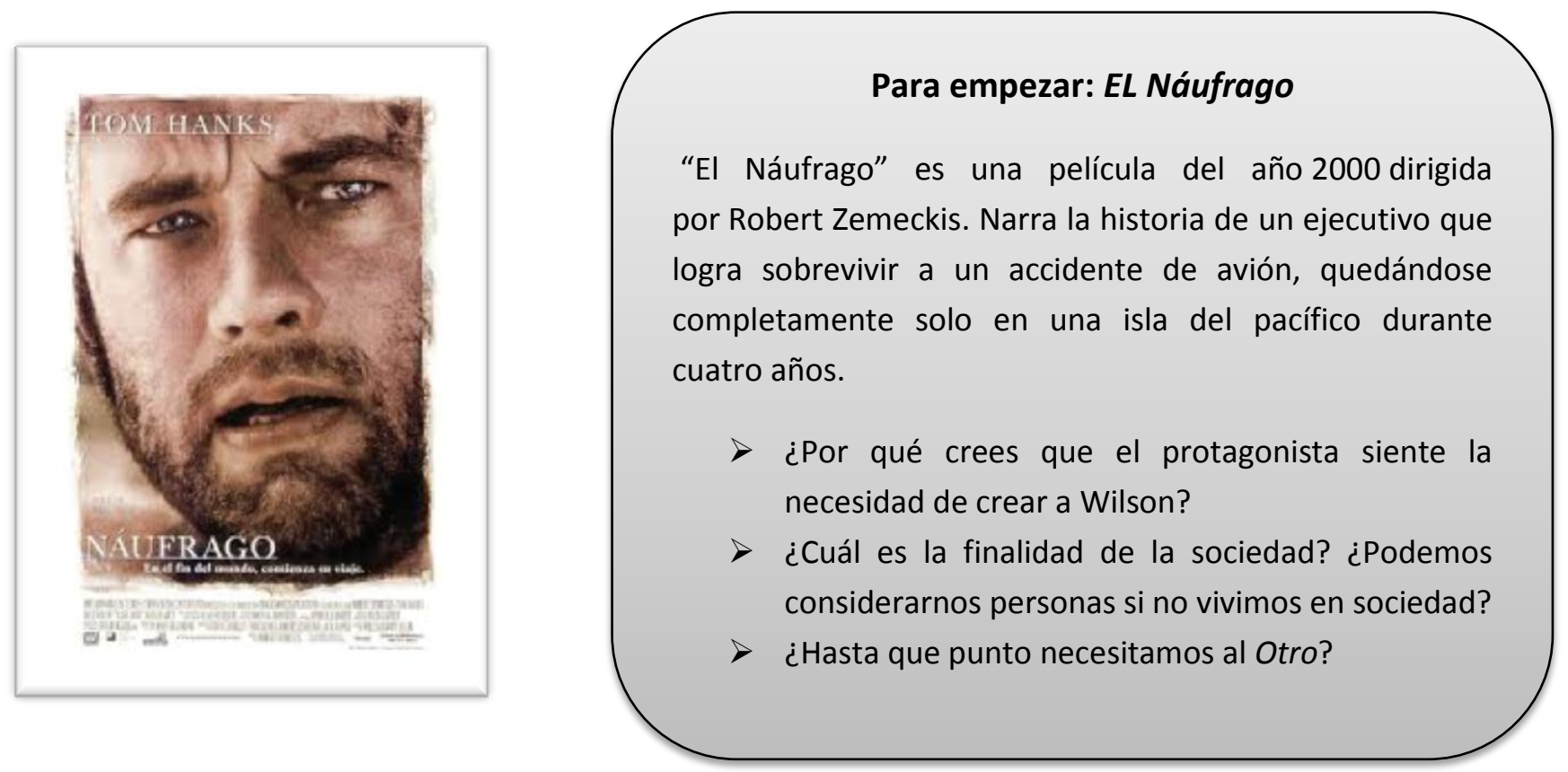


\section{El carácter cultural del ser humano}

Cultura, en latín, significa primariamente "agricultura". Y todavía nosotros hablamos de la "cultura de arroz" y calificamos de "incultos" a los campos no cultivados. Desde la revolución cultural del Neolítico, la agricultura es uno de los ingredientes básicos de la mayoría de las culturas y, desde luego, de la nuestra. La agricultura no es algo congénito; es algo que se aprende. El agricultor necesita aprender -de sus padres, de la en qué época se roturan las tierras, qué semillas se siembran, qué abonos se aplican, cómo y con qué instrumentos se practica la recolección, et. [...]. El lenguaje, por ejemplo, forma parte de la cultura, pues el hablar -a diferencia del llorar o el reírrequiere un aprendizaje. Nadie nace sabiendo hablar [...]. También hemos de aprender a limpiarnos los dientes y a conducir automóviles, a buscar trabajo y a pedir créditos, a obedecer y a mandar, a saludar y a resolver ecuaciones de segundo grado, a bailar el tango y a cantar gregoriano. Todo esto forma parte de nuestra cultura.

Mosterín, J., Racionalidad y acción humana. escuela o de donde sea- cómo y

\subsection{Animal racional}

¿Qué es lo distintivo del ser humano? ¿Qué entendemos por naturaleza humana? Las respuestas a estas preguntas plantean una gran dificultad, por ello, sería conveniente que abordásemos tres dimensiones (biológica, cultura y racional) que de manera conjunta nos ayudaran a dibujar una posible respuesta.

Para empezar nuestra explicación sobre el ser humano, podríamos remontarnos a los orígenes del mismo y definir cómo se ha formado, qué factores o acontecimientos han contribuido a su desarrollo y nos han hecho ser de la manera que somos. Entonces tendríamos que dar cuenta del proceso evolutivo del ser humano que va desde las formas más antiguas de primates hasta nuestros antepasados más cercanos, los homínidos. Sin embargo, el ser humano no hace su aparición en la historia hasta que se produce la humanización (primeras especies que pueden considerarse humanas). La determinación biológica y genética con la que nacemos constituye nuestra dimensión natural o biológica.

Pero parecería que el ser humano es "algo más" que rebasa esa dimensión biológica. De manera que podríamos añadir que poseemos una segunda dimensión, la dimensión cultural. Todo lo adquirido socialmente, como los conocimientos, técnicas, hábitos, normas, moral, arte, derecho, ciencia y religión, forman parte de esta dimensión.

La cultura es el conjunto de informaciones adquiridas por medio del aprendizaje social. De manera que la cultura supone un modo de orientación y de adaptación al mundo en que vivimos. Así, nos permite, a través del lenguaje simbólico y la técnica, desenvolvernos en la sociedad reduciendo la complejidad de la experiencia y dotándonos de las herramientas necesarias para lograr cierta seguridad y confianza ante las situaciones a las que nos enfrentamos diariamente.

La tercera dimensión es aquella que hace mención a una característica propia y distintiva del ser humano: la razón. En efecto, somos animales racionales, y esta cualidad nos permite decir que más allá de las determinaciones biológicas y culturales somos seres libres. Esta definición tan sencilla fue ideada por el mundo griego que supo

\section{ACTIXIRAR:}

Enumera las características principales y definitorias del ser humano.

captar la dimensión racional del hombre. En ella se encuentra la verdadera diferencia entre el hombre y el animal. 
Por lo tanto, podríamos concluir constatando que el ser humano no está hecho, sino que trabaja para hacerse así mismo, y además es el único ser capaz de actuar de manera autónoma elaborando sus propias leyes, puesto que es un ser racional. En otras palabras:

“No nos queda, pues, para señalarle al hombre la clase a la que pertenece en el sistema de la naturaleza viva y así caracterizarle, otra cosa sino decir que tiene un carácter que él mismo se ha creado, al ser capaz de perfeccionarse de acuerdo con los fines que él mismo se señala; gracias a lo cual, y como animal dotado de la facultad de razón, puede hacer de si un animal racional" ( Immanuel Kant, Antropología, Alianza, Madrid, 1991)

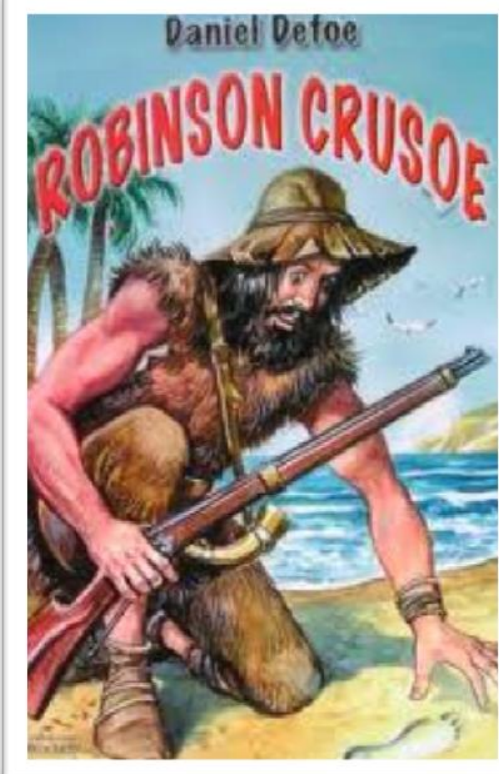

Robinson Crusoe, de Daniel Defoe, narra la historia de un joven náufrago que sobrevive 28 años en una remota isla tropical. Es un buen ejemplo de la necesidad que siente el ser humano de convivir con otros y de establecer relaciones de reciprocidad.

\subsection{Convivencia e intersubjetividad}

Los seres humanos vivimos en un mundo, insertos en proyectos y en relaciones con las cosas. Pero también existimos en las relaciones que establecemos con las otras personas. Nuestra vida transcurre rodeada de otros yos con los que interactuamos de manera activa.

Estas relaciones con los otros yos son necesarias y originarias, y crean la convivencia. Con-vivimos, esto es, intentamos vivir en buena armonía con los demás. Pero la convivencia hay que construirla, e implica entre otras cosas, aprendizaje. Y es que cuando dos o más personas o grupos que son diferentes entran a formar parte de una serie de relaciones sujetas a cambios incesantemente, pueden producirse situaciones de conflicto. De ahí que tengamos que adaptarnos a las demandas del otro, a las situaciones diferentes y ser flexibles.

Por otra parte, la convivencia exige tolerancia, en el sentido de aceptar que el otro es diferente. Pero también requiere el establecimiento de unas normas comunes, eso que solemos llamar "normas de convivencia". Y es que convivir no significa lo mismo que coexistir. Cuando las personas coexisten no establecen vínculos entre sí y sólo comparten un territorio común. Esta actitud puede llevar a crear situaciones de hostilidad hacia el diferente.

Así pues, el ser humano no es una realidad cerrada sobre sí misma, sino que necesita de los otros para existir, necesita el reconocimiento de los otros sujetos. La realidad social se define por esa continua identificación mutua que se da entre los sujetos. La necesidad de existir va de la mano de la necesidad de reconocimiento: porque me relaciono con el otro y en su mirada me reconozco, existo.

Si no tenemos reconocimiento, nos angustiamos y nos sentimos solos. Pero peor que la soledad es estar con otros que no nos reconocen. Es la angustia superior a todas las fuerzas, superior a cualquier castigo físico, ese sentir que uno ha dejado de existir pero que su corazón sigue latiendo. No encajas, pero estás, no te miran, pero estás ahí. Ralph Ellison, un chico negro americano, lo definió con las siguientes palabras: "A menudo le sucede a uno que duda realmente de su existencia. Es devorado por la necesidad de convencerse de que existe, realmente, en el mundo real...lanza sartas de injurias, y jura que los llevará a todos a que lo reconozcan".

Otros pensadores, como Ortega, han indagado sobre esta necesidad de reconocimiento, y sobre ese carácter abierto y relacional que forma parte de la vida social de todo ser humano. En el texto que se propone a continuación, Ortega nos explica cómo las relaciones que establecemos con los otros son complejas y diversas. 
Tenemos, pues, que el hombre, aparte del que yo soy, nos aparece como el otro, y esto quiere decir -me interesa que se tome en todo su rigor-, el otro quiere decir aquel con quien puedo y tengo- aunque no quiera- que alternar, pues aun en el caso de que yo prefiriera que el otro no existiese, porque lo detesto, resulta que yo irremediablemente existo para él y esto me obliga, quiera o no, a contar con él y con sus intenciones sobre mí, que tal vez son aviesas. El mutuo "contar con" la reciprocidad, es el primer hecho que nos permite calificarlo de social. [...]

Esto significa que la aparición del Otro es un hecho que queda siempre como a la espalda de nuestra vida, porque al sorprendernos por vez primera viviendo, nos hallamos ya, no sólo con los otros y en medio de los otros, sino habituados a ellos. Lo cual nos lleva a formular este primer teorema social: el hombre está a nativitate (desde el origen, desde el nacimiento) abierto al otro que él, al ser extraño; o con otras palabras: antes de que cada uno de nosotros cayera en la cuenta de sí mismo, había tenido ya la experiencia básica de que hay los que no son "yo", los Otros; es decir, que el Hombre, al estar a nativitate abierto al otro, al alter que no es él, es, a nativitate, quiera o no, le gústele o no, altruista. Pero es menester entender esta palabra y toda esta sentencia sin añadirle lo que en ella no va dicho.

\section{ACTIYIRAR;} Ortega y Gasset, J., "El hombre y la gente", en Obras completas, VII.

Ortega nos habla de la necesidad de los otros para dar sentido a nuestra vida, ¿qué valor puede tener la vida de alguien que decide vivir en completa soledad? ¿Es posible una vida plena en soledad?

- Analiza el texto y extrae las ideas principales.

\section{La dimensión social de la vida humana}

\section{1. ¿El ser humano es un ser social por naturaleza?}

La tendencia del ser humano ha vivir en sociedad recibe el nombre de sociabilidad. Se trata de un hecho inmediato, en la medida en que desde que nacemos nos hayamos insertos en un medio social. Se trata, además, de un hecho irreversible en tanto que no nos es posible abandonar de una manera absoluta y definitiva la sociedad en la que vivimos. Nuestro carácter social nos inclina a desear vivir con otros seres semejantes a nosotros. Ello supone compartir un territorio común y la necesidad de garantizar la supervivencia de cada individuo, así como la del grupo.

Pero, podemos plantearnos la siguiente cuestión: ¿vivimos con otros individuos porque nuestra naturaleza nos lo exige? ¿O es una mera casualidad? Si respondemos afirmativamente a la primera cuestión, entonces el vivir en sociedad con otros individuos es necesario y propio de la naturaleza del ser humano. Pero si consideramos la segunda opción, entonces el compartir la vida con otras personas es puramente accidental y casual. Esto nos llevaría a plantearnos la cuestión de si somos seres humanos real y completamente antes de vivir en sociedad e independientemente de las relaciones que establecemos con las otras personas. En otras palabras, nos preguntamos si las relaciones que establecemos con los demás son relaciones originarias, constitutivas y fundamentales para nuestra vida.

En definitiva, en este epígrafe discutimos si la sociabilidad humana es natural o interesada. Veamos algunas teorías que intentan dar respuesta a nuestro interrogante.

\section{El ser humano es sociable por naturaleza}

Esta postura tiene como principal representante a Aristóteles, quien afirmó que "El hombre es por naturaleza un animal social". Aristóteles parte de la idea de que el hombre es un animal político que 
necesita de la sociedad (la pólis) para desarrollar plenamente todas sus capacidades. Es político en la medida en que es ciudadano de una ciudad-estado, en tanto que convive en una sociedad civil y política.

Aristóteles concibe al ser humano como un ser incompleto, lleno de carencia y de necesidades, y que por tanto, necesita de los demás para poder desarrollarse. Sólo en sociedad puede alcanzar la virtud y la felicidad que su propia naturaleza le exige. Por ello, resulta evidente la ciudad es una cosa natural y que sólo "un dios o una bestia" pueden prescindir de ella.

De esta manera, ser "social y político" es algo propio, peculiar y definitorio de la naturaleza humana. El hombre es el único ser capaz de vivir en sociedad, porque sólo él sabe distinguir lo bueno de lo malo, lo justo de lo injusto. Esto es, es un ser dotado de razón y de lenguaje, lo que le permite expresar su naturaleza moral, que es la base de la condición social.

\section{Vivir en sociedad no es una exigencia de la naturaleza.}

Quienes defienden esta posición, estiman que el hombre no es un ser social por naturaleza, sino por interés. En este sentido, el ser humano se vería obligado a crear la sociedad para garantizar su propia supervivencia. De esta manera, la sociedad surgiría fruto de un acuerdo o contrato que impediría el estado permanente de guerra, a la vez que garantizaría una precaria coexistencia. Como representantes de esta corriente podríamos citar a los siguientes pensadores:

\section{Thomas Hobbes (1588-1679)}

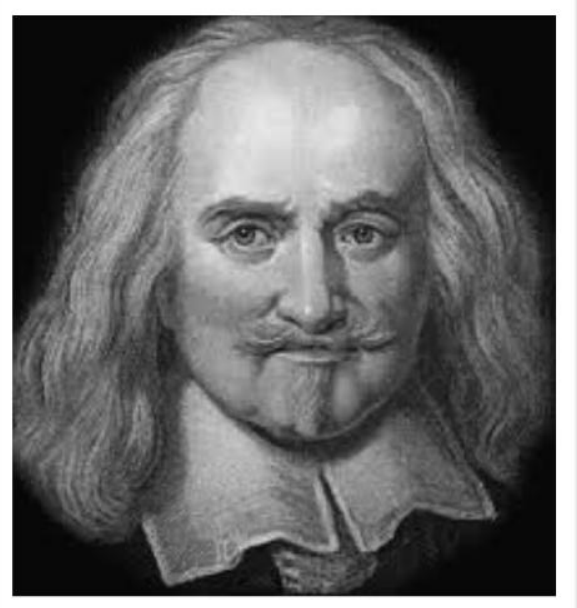

En una condición así [en el estado de naturaleza], no hay lugar para el trabajo, ya que el fruto del mismo se presenta como incierto; $y$, consecuentemente, no hay cultivo de la tierra; no hay navegación, y no hay uso de productos que podrían importarse por mar; no hay construcción de viviendas, ni de instrumentos para mover y transportar objetos que requieren la ayuda de una fuerza grande; no hay conocimiento en toda la faz de la tierra, no hay cómputo del tiempo; no hay artes; no hay letras; no hay sociedad. $Y$ lo peor de todo, hay un constante miedo y un constante peligro de perecer con muerte violenta. $Y$ la vida del hombre es solitaria, pobre, desagradable, brutal y corta.

Hobbes, T., Leviatán

\section{ACTIYIRAD:}

Investiga qué entiende Hobbes por naturaleza y luego explica qué quiere decir cuando afirma que el hombre no es social por naturaleza.

Hobbes mantiene una concepción pesimista del ser

humano, donde los hombres son egoístas y sólo buscan satisfacer sus propias necesidades y deseos.

Comienza reflexionando sobre un hipotético estado de naturaleza o estado originario, en el que los seres humanos vivirían atacándose los unos a los otros. Así, el "hombre es un lobo para el hombre", que sólo ve en las otras personas o bien, posibles rivales o medios para satisfacer sus deseos. Hobbes concibe tres posibles razones importantes para atacar a otros en el estado de naturaleza: por ganancias, por seguridad, y por gloria o reputación. Los hombres padecerían un estado de guerra de todos contra todos, ya que intentarían constantemente y a cualquier precio incrementar su poder, usando la violencia y la fuerza y desposeyendo a los otros, inclusive de su libertad o de su vida. 
Pero, surge en los hombres el deseo de abandonar esa "miserable situación de guerra que se vincula necesariamente a las pasiones naturales de los hombres cuando no hay poder visible que los mantenga en el temor" (T. Hobbes, Leviatán).

Para garantizar la seguridad y preservación de la propia vida y de los bienes o propiedades que se poseen, los hombres deben llegar a un acuerdo para instituir un soberano que castigue a aquellos que desobedezcan las leyes. De esta manera, los hombres libremente decidirán ceder su poder a un solo jefe fuerte y absoluto elegido por todos, que tendrá el poder suficiente para hacer imponer las leyes y garantizar una convivencia pacífica.

Jean- Jacques Rousseau (1712-1778)

Los filósofos que han examinado los fundamentos de la sociedad han sentido la necesidad de remontarse hasta el estado de naturaleza, pero ninguno ha llegado hasta él...Finalmente todos, hablando sin cesar de necesidad, de avidez, de opresión, de deseos y de orgullo, han transferido al estado de naturaleza ideas que habían cogido de la sociedad. Hablaban del hombre salvaje y pintaban al hombre civil.

Rousseau, J., Discurso sobre el origen de la desigualdad.

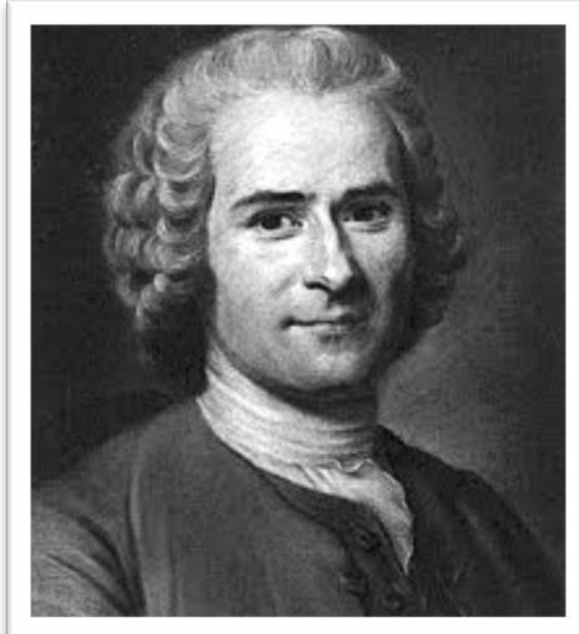

El planteamiento de Rousseau comparte con Hobbes la creencia de que los seres humanos se mueven principalmente por el deseo de supervivencia. Pero Hobbes ha obviado un rasgo esencial del ser humano: la piedad y la compasión. Porque el hombre "siente una repugnancia innata a ver sufrir a un semejante". De manera que la compasión es una motivación humana que frena los impulsos de guerra y ataque. Según Rousseau, "es ella (la compasión) la que, sin reflexión, nos lleva en socorro de aquellos a quienes vemos sufrir; es ella la que, en el estado de naturaleza, hace de leyes, de costumbres y de virtud, con la ventaja de que nadie se siente tentado a desobedecer a su dulce voz: es ella la que hará desistir a todo salvaje robusto de quitar a un débil niño, o a un viejo inválido, su subsistencia adquirida con esfuerzo, si él mismo espera poder encontrar la suya en otra parte" (JeanJaques Rousseau, Discurso sobre el origen y los fundamentos de la desigualdad). Por lo tanto, para Rousseau el hombre es bueno por naturaleza.

Sin embargo, cuando el hombre comienza a conformar una sociedad, aparece el reclamo de la propiedad privada y de las reglas de justicia. Por lo tanto, la sociedad civilizada es el comienzo del hombre malvado y corrompido, que se torna egoísta al hacerse sociable.

\section{ACTIVIRAR:}

Realiza un cuadro comparativo entre las posiciones de Aristóteles, Hobbes y Rousseau.

De ahí que surja la necesidad de establecer sociedades civiles -sociedades con leyes y gobiernos-. Estas sociedades nacen producto del acuerdo entre los hombres y manifiestan la "voluntad general" del pueblo. 


\section{Los procesos de socialización}

\subsection{Ser persona: identidad personal e identidad social}

\section{Una definición de persona}

Una persona es un ser espiritual constituido como tal por una forma de subsistencia y de independencia en su ser; mantiene esta subsistencia mediante su adhesión a una jerarquía de valores libremente adoptados, asimilados $y$ vividos en un compromiso responsable y en una libertad y desarrolla además, por impulsos de actos creadores, su vocación personal.

Mounier, E., Manifiesto al servicio del personalismo.

En el apartado anterior estudiamos que el ser humano vive en sociedad ya sea por naturaleza o por interés, pero en cualquier caso se siente abocado a vivir rodeado de otros, a relacionarse con ellos y a desarrollarse como persona.

Todos nacemos en un determinado contexto social, en un país, una provincia, en un barrio y en una familia, y poco a poco vamos constituyendo nuestra identidad social, a la vez que vamos adquiriendo la identidad personal. La identidad social se construye en las relaciones que establecemos con los otros y nos permite mantener unos valores compartidos con las personas de nuestra sociedad. Por otra parte, la identidad personal hace referencia a nuestra particularidad como sujetos únicos e irrepetibles.

Así, nuestra vida transcurre atravesada por un doble sentimiento de identidad que en primera instancia podría parecer paradójico puesto que, por un lado necesitamos identificarnos con los demás para sentirnos parte de algo, pero por otro lado, queremos diferenciarnos de los otros para no confundirnos con ellos y poder sentirnos nosotros mismos. Ambos procesos transcurren simultáneamente y nos ayudan ha convertirnos en personas y en ciudadanos.

\section{Descubrir la propia identidad}

Considérese lo que entendemos por identidad: quiénes somos, "de dónde venimos". Como tal, es el trasfondo frente al cual nuestros gustos y deseos, opiniones y aspiraciones adquieren sentido [...]. Que yo descubra mi propia identidad no significa que yo la haya elaborado en el aislamiento, sino que he negociado con los demás por medio del diálogo, en parte abierto, en parte interno. Por eso, el desarrollo de un ideal de identidad que se genera internamente atribuye una nueva importancia al reconocimiento. Mi propia identidad depende, en forma crucial, de mis relaciones con los demás.

Charles, T., El multiculturalismo y "Ia política del reconocimiento".

\subsection{El problema de la identidad personal}

La experiencia de la identidad personal o individual, nos hace pensar sobre nuestro carácter de seres únicos, exclusivos e irrepetibles. Cuando empleamos la palabra "Yo" nos referimos a esa sensación de permanencia y continuidad a lo largo del tiempo, del espacio, y de las diferentes situaciones sociales. Podríamos decir que el "Yo" hace referencia a nuestra personalidad desde un punto de vista subjetivo. El cuerpo adquiere un papel importante cuando reflexionamos sobre nosotros mismos, dado que el yo se conoce a sí mismo como una unidad configurada en el propio cuerpo. Otro rasgo relevante es la unidad de la conciencia, esto es, aunque nuestros pensamientos, recuerdos, deseos cambien con el tiempo, tenemos la certeza de que siempre es la misma conciencia la que piensa, recuerda y desea. Mirándonos a nosotros mismos, por la introspección u observación propia, y por la observación de los demás, podemos hacernos una idea de quienes somos.

Pero, ¿̇qué es el Yo? A continuación estudiaremos la posición de David Hume (1711-1776) quien en su Tratado de la naturaleza humana estudió la problemática en torno a la idea del Yo. 


\section{David Hume y el problema de la identidad personal}

En lo que a mi respecta, siempre que penetro más íntimamente en lo que llamo mí mismo tropiezo en todo momento con una u otra percepción particular, sea de calor o de frío, de luz o de sombra, de amor o de odio, de dolor o placer.... Nunca puedo atraparme a mí mismo en ningún caso sin una percepción...Cuando mis percepciones son suprimidas durante algún tiempo: en un sueño profundo, por ejemplo,....no me doy cuenta de mí mismo, y puede decirse que verdaderamente no existo. $Y$ si todas mis percepciones particulares fueran suprimidas y ya no pudiese pensar, sentir, ver, amar $u$ odiar tras la desaparición de mi cuerpo, mi yo resultaría completamente aniquilado....Si tras una reflexión seria y libre de prejuicios hay alguien que piense que él tiene una noción diferente de sí mismo, tengo que confesar que ya no puedo seguirle en mis razonamientos.

Hume, D., Tratado de la naturaleza humana.

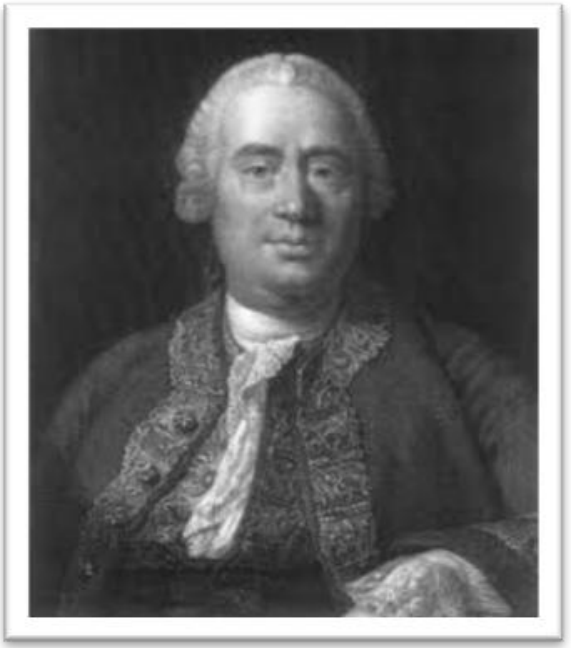

Para entender el análisis del Yo que realiza Hume, tenemos que saber cuál es su concepción de la mente. Para Hume, lo que hay en la mente son percepciones, y una percepción es cualquier cosa que podamos pensar (ideas) o sentir (impresiones).

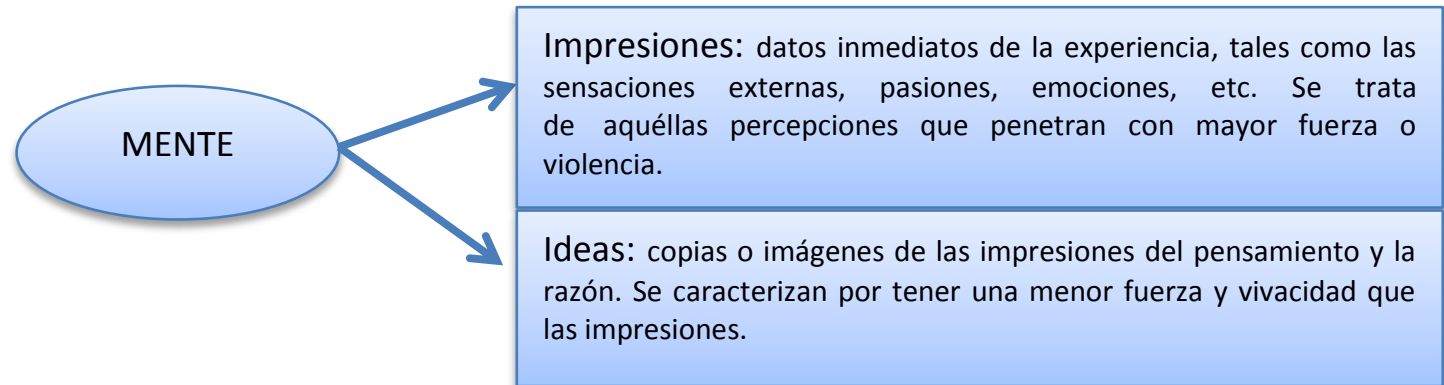

Los filósofos anteriores a Hume habían sostenido que para que fuera posible el pensamiento hacía falta que alguien lo pensara. Así, Descartes afirmó que "Pienso, luego existo". Pero para Hume, el pensamiento no necesita de algo ni de alguien que lo piense. En otras palabras, lo único necesario para que se produzca el pensamiento es el propio pensamiento.

Si ahora examinamos nuestra mente, nos percataremos de que en ella se dan una serie de percepciones: ahora sentimos el papel del libro, sentimos nuestro cuerpo sentado, un ruido...etc. Pero si continuamos intentando buscar nuestro Yo, ese Yo sujeto de todas las

\section{ACTIYIRAR:}

Visualiza el corto "Hume, Shrek y las cebollas" y explica con tus propias palabras que es el Yo para Hume, ¿̇estás de acuerdo? percepciones que estamos teniendo ¿qué encontramos? Lo único que encontramos son nuestros pensamientos, incluso el pensamiento de "estoy buscando mi Yo". Como dice Hume, cada vez que penetras en ti mismo, lo que encuentras son las percepciones, no a ti mismo. Nunca te atraparás a ti mismo sin una percepción y nunca sentirás algo que no sea una percepción. 
De ahí que la imaginación acepte la idea de Yo, la cual no es más que una idea que no ha sido originada por ninguna percepción y, por tanto, no existe en la realidad un Yo. De la misma manera, no existe un unicornio en la realidad, pero sí que tenemos una idea del mismo que nos permite pensarlo. Así, el Yo no es más que una categoría lógica y gramatical de sujeto, pero en ningún caso es una figura o entidad de la realidad.

\subsection{La socialización y sus formas}

Todos vivimos en una sociedad, pero para llegar a hacerlo, tuvimos que aprender una serie de normas, conocimientos y habilidades. Imaginemos que ahora marchamos a vivir a Japón, tendríamos, entre otras cosas, que aprender el idioma, conocer las reglas de comportamiento (cómo saludar, cómo despedirse, etc.), creencias y costumbres. Sería como entrar a formar parte de un mundo nuevo, y para lograr nuestra tarea con éxito deberíamos someternos a un largo y arduo proceso de aprendizaje. Pues bien, esto es lo que hacemos desde que nacemos casi de una manera natural y sin esfuerzo.

Pero ¿qué es la socialización? Socialización o aculturación, hace referencia al proceso mediante

La socialización es el proceso mediante el cual el individuo es absorbido por la cultura de su sociedad. Fundamentalmente, la socialización es un aprendizaje; en su virtud, el individuo aprende a adaptarse a sus grupos, y a sus normas, imágenes y valores. Trátase de un proceso de aprendizaje de conducta ( $y$ de ideas y ciencias que a la postre han de plasmarse en la conducta). Como proceso es permanente, pues dura toda la vida del individuo y es perenne en la sociedad.

Para el individuo, la socialización es particularmente intensa durante sus primeros años. $Y$ es durante la infancia cuando más clara se ve la naturaleza de la socialización, la cual es, en su carácter de aprendizaje, un proceso de "interiorización" normativa, imaginativa y valorativa.

Giner, S., Sociología. el cual el individuo aprende e interioriza la cultura de la sociedad en la que vive. Se trata de un proceso de integración del individuo en la sociedad y en las instituciones que la conforman. Consiste, básicamente, en la interiorización de las reglas, principios y costumbres propias de la cultura de la que formamos parte y que nos servirá para desarrollar nuestra identidad personal a la vez que construimos la identidad social.

La socialización es un proceso que dura toda la vida, no es específico de una etapa sino que se extiende, restaura y fortalece constantemente. Ahora bien, suelen distinguirse dos etapas:

\section{Socialización primaria}

Tiene lugar en la infancia, desde los primeros años de vida. Gracias a la socialización primaria el niño se familiariza con su entorno más cercano y aprende las pautas y costumbres del grupo (padres, abuelos, hermanos, maestros, etc.). Este proceso de aprendizaje se desarrolla gracias a la capacidad del niño de imitar e identificarse con los agentes socializadores del mundo que le rodea.

El mecanismo mediante el cuál se asimilan las normas y valores es el de la generalización progresiva. Partiendo de un hecho particular, como por ejemplo la ruptura de un juguete, los padres enseñan a sus hijos que esta actitud es negativa, hasta que el niño adopta la norma de no romper juguetes. También se emplea la concesión de premios y castigos, por ejemplo: si rompes los juguetes de tu hermano, no iremos al parque.

La socialización primaria está impregnada no sólo de la adquisición intelectual de conocimientos, sino que posee una gran carga emocional y afectiva. Los vínculos afectivos que se establecen con los padres, hermanos y demás personas del entorno constituyen una poderosa fuerza de unión con los 
demás, y a la vez, conforman la base para el correcto desarrollo social del niño. Ahora bien, durante esta primera etapa no hay ni consciencia ni deliberación, y resulta sumamente importante dado que constituye la formación de nuestro primer mundo, y de su éxito dependerá la formación y adaptación a la siguiente etapa.

\section{Socialización secundaria}

Se produce a lo largo de la vida, y se refiere a los procesos posteriores que llevan al individuo a nuevos ámbitos sociales fuera de la familia. Nos permite interiorizar los mundos institucionales y descubrir que el mundo de los padres no es el único. La socialización secundaria puede darse de forma deliberada y consciente, dado que en esta etapa, el individuo puede elegir el grupo, o la institución de la que desea formar parte. Es una socialización menos intensa, dado que las interacciones sociales que se producen en esta etapa tienen una menor carga afectiva. No se exige a los individuos cuando van al trabajo o están en la calle que mantengan un trato afectivo como el que se da en la familia.

Otra diferencia radica en que, mientras la transmisión del conocimiento se daba de manera prácticamente automática en la socialización primaria, en la secundaria debe ser reforzado con técnicas pedagógicas que faciliten el aprendizaje de normas sociales, valores culturales, roles concretos, etc.

Durante este proceso el individuo se readapta a cambios en el entorno o a nuevas circunstancias, lo cual puede producir una crisis de crecimiento. Este proceso de maduración puede conducir al individuo a plantearse problemas de coherencia personal y de identificación. Si bien, es posible que esas crisis no aparezcan si se ha dado una socialización primaria exitosa.

\section{Resocialización}

La resocialización ocurre cuando comenzamos a formar parte de una sociedad diferente de aquella en la que nos hemos socializado. Requiere interiorizar los contenidos culturales de la nueva sociedad, es decir, sus costumbres, roles, actitudes, valores culturales, etc. La resocialización también puede darse cuando la sociedad en la que vive el individuo sufre un cambio radical o repentino.

Durante la resocialización, no se parte de cero, sino que el individuo debe aprender, así como hizo en la socialización primaria, todos aquellos conocimientos que le permitirán adentrarse en la nueva sociedad. Para ello, deberá olvidar la anterior perspectiva de la realidad, a la vez que se produce una fuerte identificación afectiva con el nuevo grupo.

Puede producirse cuando el individuo sufre una crisis profunda, ya sea una crisis de identidad, de crecimiento, de cambio social o de choque cultural

\section{ACTIXIDADES;}

-Escribe un ejemplo de cada tipo de socialización. -Enumera los agentes de socialización que aparecen en la socialización secundaria. -¿Qué tipo de socialización viven los inmigrantes? - ¿Crees que los medios de comunicación influyen en nuestra socialización? ¿Qué medio destacarías? ¿Por qué?

provocado por la emigración a otro país. 
Un ejemplo de resocialización es el proceso por el que pasaron unos soldados americanos en los años 50 al final de la guerra de Corea. Estos soldados, después de haber estado presos, empezaron a defender la causa comunista. Se produjo un cambio total de bando y de ideología. Se produce una nueva interpretación de los hechos y de la propia persona, acorde a los nuevos contenidos interiorizados.

\section{La importancia de la cultura}

\subsection{Características de la cultura}

Como vimos en el primer epígrafe de este tema, la cultura supone un modo de orientación y de adaptación al mundo en que vivimos. Una de las primeras formulaciones de cultura la realizó el antropólogo británico Edward B. Tylor (1832-1917): “Cultura o civilización, tomada en su amplio sentido etnográfico, es ese complejo de conocimientos, creencias, arte, moral, derecho, costumbres y cualesquiera otras aptitudes y hábitos que el hombre adquiere como miembro de la sociedad".

Por tanto, la cultura es un producto específicamente humano, que a modo de una herramienta, le permite al ser humano expresar su propio modo de vida. La cultura posee las siguientes características:

\section{a) La cultura humana es social}

La cultura se hereda socialmente; si bien cultura y sociedad son términos diferentes, mantienen conexiones entre sí. En la medida en que una sociedad es un sistema de relaciones entre individuos que comparten una misma cultura. Los miembros de una sociedad se identifican con una serie de valores compartidos, normas y bienes materiales que producen. De esta manera, no puede darse una cultura sin sociedad.

\section{b) La cultura humana es plural}

La cultura no es algo único, homogéneo y determinado, sino que es tan plural como los seres humanos que la conforman. Se trata de un fenómeno dinámico, que continuamente se está transformando y expandiendo.

\section{c) La cultura humana es simbólica}

El ser humano posee la capacidad del lenguaje, y éste le permite expresarse a sí mismo y al mundo que le rodea para poder transmitirlo a sus congéneres. A su vez, la cultura permite expresar el universo simbólico que crea el hombre, con sus mitos, religiones, artes, etc.
La cultura es el modo que el hombre tiene de situarse en el mundo. Es el comportamiento aprendido en el seno de la sociedad. Podríamos definir la cultura como el modo de vida de un pueblo, como el medio que un grupo de seres humanos que ocupan un territorio común ha creado a través de sus ideas, de sus instituciones, de sus utensilios, de su idioma, de sus herramientas, de sus servicios y de sus sentimientos.

Este medio creado por el hombre, esta cultura, es el que toda sociedad humana hace prevalecer sobre el medio puramente físico y, en el seno del cual, el hombre se educa. La cultura se identifica hasta tal punto con la propia vida que podríamos decir, con toda justicia, que la cultura no se impone a la vida, sino que es un ensanchamiento de la vida. De igual modo que una herramienta amplía y extiende las posibilidades vitales.

Montagu, A., Homo sapiens: dos millones de años sobre la Tierra.

\section{d) La cultura humana es aprendida.}

La cultura requiere aprendizaje y ejercicio. Como vimos en el epígrafe anterior, mediante los procesos de socialización nos son transmitidos los conocimientos y experiencias de los agentes 
socializadores, conocimientos necesarios para desenvolvernos y orientarnos en la sociedad. El ser humano, es el animal que mayor predisposición y facilidad tiene para aprender nuevas pautas de conducta y adaptarse al medio.

\section{e) La cultura humana es histórica}

La cultura trae consigo las experiencias, vivencias y conocimientos de todas las personas que nos precedieron. Así, pues, nacemos en el seno de una tradición que hemos heredado. La tradición está formada por contenidos culturales que nos son transmitidos como mundos de sentidos. Recibimos, incorporamos y transmitimos esos mundos a las generaciones venideras y así vamos incrementando nuestro capital cultural.

\subsection{Subcultura y contracultura}

La cultura no es un todo homogéneo, sino que dentro del gran abanico de hábitos, costumbres y creencias, podemos detectar pequeños grupos o subculturas. La subcultura es un grupo cultural diferente al de la cultura dominante, que existe como un segmento claramente identificable dentro de una sociedad compleja. Los miembros de una subcultura específica mantienen creencias, valores y costumbres que les diferencian de la cultura predominante, pero comparten con la mayoría las reglas y valores culturales de la sociedad general. Por ejemplo, una comunidad de inmigrantes conformaría una subcultura, en la medida que mantendría sus ejes simbólicos recreando sus contenidos culturales.

Por su parte, la contracultura se presenta como un movimiento articulado que se contrapone a la cultura dominante. Presenta un sistema propio de valores, conductas y estilos que conforman un proyecto de cultura alternativa. De esta manera, la contracultura, a diferencia de la subcultura, presenta un elemento disfuncional al sistema, ya que elabora esquemas de conducta que se oponen a la cultura hegemónica.

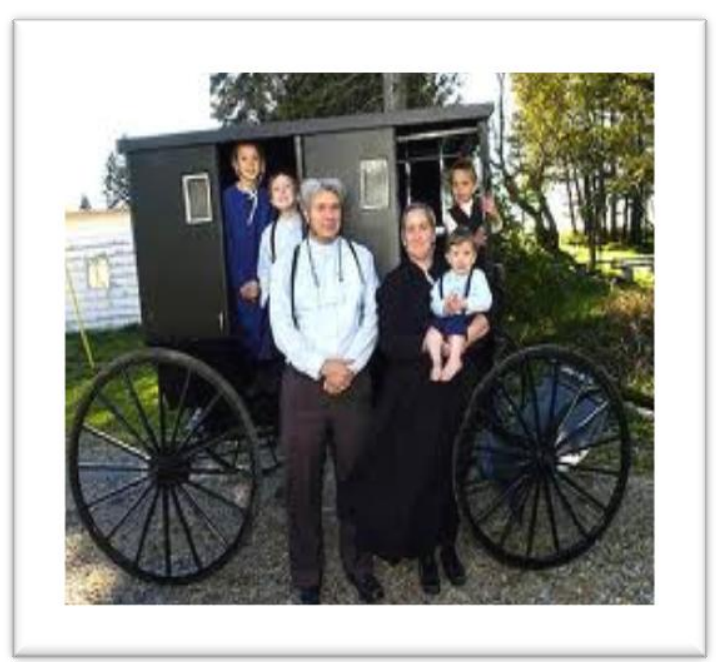

\section{ACTIYIRARES;}

Los Amish son un grupo religioso y étnico que vive en veintidós asentamientos en Estados Unidos. Los Amish se han quedado detenidos en el tiempo, viven aislados y según las costumbres y valores de las sociedades del siglo XVIII. Defienden el pacifismo, la vida sencilla y restringen enormemente el uso de las tecnologías modernas.

¿Crees que los Amish podrían ser calificados como contracultura o como subcultura? ¿Por qué?

Clasifica los siguientes grupos argumentando en cada caso tu elección:

-Comunidad judía de Zaragoza

-Poblado de gitanos a las afueras de Granada

- Asociación filatélica de Murcia

-Grupo de acción ecologista. 
Algunos ejemplos de manifestaciones contraculturales son:

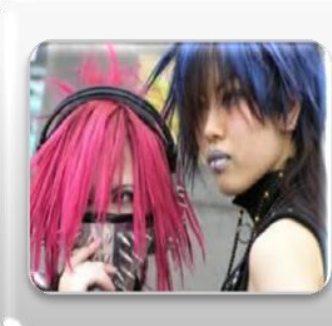

\section{Las tribus urbanas}

Se trata de agrupaciones de jóvenes que quieren descubrir una identidad que ni la familia ni la sociedad les proporcionan. Para ello, se reunen generalmente en torno a un líder, se visten de un modo parecido, siguen hábitos comunes (comparten la música, un lenguaje, un lugar de reunión, etc). Estos grupos son visibles en las ciudades.

Ejemplos: gótico, metalero, electro, graffitero, punk, cluber, etc.

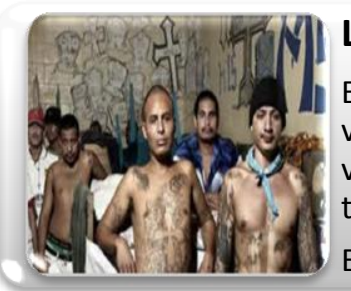

\section{Los grupos de ataque social}

Estos grupos están constituidos por bandas de delincuentes que a través de la violencia buscan desestabilizar el sistema establecido. el ataque directo y la violencia, son carectarísticos de otros grupos adolescentes que pretenden transgredir las leyes para crear un nuevo estado social.

Ejemplos: skinheads neonazis, bandas de delicuentes, etc.

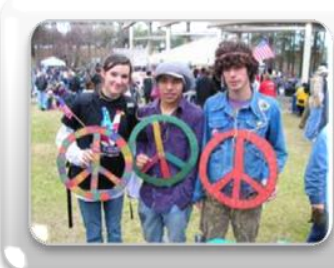

\section{Los grupos sociales alternativos}

Estos grupos intentan crear un sistema de vida diferente al hegemónico, proponiendo nuevos valores. Generalmente rechazan el materialismo social y esperan suplir el vacío existencial que les provoca el rechazo a los valores dominates, a través de diversos medios.

Ejemplos: Hippies, grupos ecologistas, Amish, etc.

\section{El reto de la diversidad cultural}

\section{1. ¿Por qué es importante reflexionar sobre la diversidad cultural?}

A lo largo de la unidad hemos ido perfilando al ser humano como un ser social y cultural. En este sentido, hemos hablado de la cultura en singular. Sin embargo, existen muchas culturas: rural, urbana, oriental, latina, protestante, cristiana, musulmana, norteamericana...Y esta pluralidad cultural a menudo la encontramos coexistiendo en un mismo territorio. Esto se debe a que vivimos en sociedades plurales, heterogéneas y dinámicas en las que continuamente se dan situaciones de contacto entre culturas. Estos contactos pueden producir un enriquecimiento de la propia cultura, pero también conflictos. Ahora bien, el que exista conflicto no es una cuestión problemática en sí misma, dado que todo conflicto es inherente al contacto entre las culturas. El problema reside en la forma en que se perciben, reciben y contestan esas situaciones de conflicto.

\section{Posturas ante la diversidad cultural}

Cuando nos encontramos con otras personas que mantienen una cultura diferente, otros valores, creencias, actitudes y modo de ver la vida, reaccionamos de diversas maneras. Algunas de las posturas que se adoptan en el encuentro cultural son las siguientes:

\section{$>$ El etnocentrismo}

¿Qué ocurre cuando culturas profundamente divergentes, con valores y costumbres muy divergentes, tienen que convivir? En esta situación, resulta inevitable que las personas realicemos comparaciones. El problema aparece cuando esa comparación se deja llevar por el prejuicio, dando 
lugar a un juicio injusto e injustificable que termina por herir a la "minoría cultural". Esto es lo que la actitud etnocentrista consigue cuando juzga y valora la otra cultura desde los criterios o creencias de su propia cultura.

El etnocentrista actúa de una manera no crítica cuando defiende su cultura sin aportar razonamientos, a la vez que desprecia y critica los elementos culturales que le parecen extraños o diferentes.

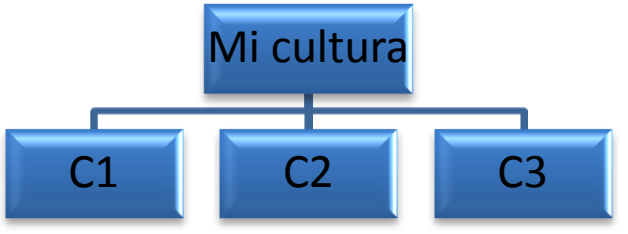

Este esquema ejemplifica el método comparativo que emplea el etnocentrista. Se trata de elevar, indebidamente, los valores de la propia cultura a valores universales. De esta manera, se proponen como los valores correctos, normales, justos y buenos, los que son conocidos y familiares. Partiendo de esa idea, la propia cultura se toma como modelo o patrón en referencia al cuál se comparan las otras culturas. Para que la comparación resulte fructífera, se necesitaría partir de valores aculturales independientes de todas las culturas. De esta manera, la comparación resultaría parcial.

El etnocentrismo cultural se produce en todas las culturas, con mayor o menor intensidad, pues va ligado a la necesidad de autolegitimación que posee toda cultura. Ahora bien, llevado al extremo puede derivar en:

$>$ Xenofobia: se trata de una actitud de desprecio hacia el xenos (el extranjero). La persona xenófoba siente odio o rechazo hacia los extranjeros. A menudo, esta actitud es producida por el miedo hacia lo diferente, o por el desconocimiento u ignorancia de la otra cultura.

“Negar a los extranjeros la entrada en nuestra ciudad, y a nuestros ciudadanos el permiso para viajar por los demás países, es una cosa que no se puede hacer en absoluto, pues se calificaría de bárbara e inhumana por los demás hombres; nos echarían en cara que teníamos la horrible costumbre de excluir de nuestro país a los extranjeros y que nuestras costumbres eran rudas y salvajes".

PLATÓN., Las Leyes

Otras manifestaciones etnocentrista son el racismo, chovinismo (patriotismo fanático) o aporofobia (rechazo, aversión, desprecio al pobre).

\section{El relativismo cultural}

El relativista cultural cree que no es posible comparar culturas, dado que cada una tiene sus propios valores y características, lo que hace imposible realizar una evaluación imparcial de todas ellas. Ninguna cultura es preferible a otra, sino que cada una tiene valor en sí misma. Nosotros no podemos juzgar desde nuestra cultura a otra, porque no entendemos los patrones por los que se rige dicha cultura.
El relativismo cultural coincide con el etnocentrismo en hacer imposible la crítica racional, pues al establecer a priori que ninguna alternativa cultural es preferible a otra, la discusión sobre qué alternativa sea preferible se convierte en un ejercicio ocioso y condenado de antemano al fracaso. El etnocentrismo nos orienta demasiado, pues nos quita la oportunidad de elección. El relativismo, por el contrario, nos orienta demasiado poco, pues trata de convencernos de la vanidad de toda elección. En la noche sin estrellas del relativismo todos los gatos son negros y todas las direcciones son equivalentes: ninguna conduce a ninguna parte. El etnocentrismo promueve el conformismo; el relativismo la indiferencia. Ambos impiden la comparación evaluativa, la ponderación objetiva y la elección y decisión racionales. 
Si bien la postura relativista supone un avance respecto al etnocentrismo, el relativista cultural promueve una actitud pasiva que puede llevar a pasar por alto actos injustos o inhumanos. Por ejemplo: si afirmamos que ninguna cultura es mejor que otra y que debemos mostrarnos tolerantes, no podríamos decir nada acerca de la lapidación, o de la violación de los derechos de los niños, etc.

Esta actitud contiene grandes limitaciones, en la medida en que no promociona el diálogo entre culturas, sino que proclama el "todo el vale" de cada cultura particular. Además, no es capaz de afrontar los siguientes riesgos:

- El racismo: se denomina racismo a toda creencia, conducta o actitud que considera que existen unas razas superiores a otras. La persona racista considera que lo mejor es que cada uno viva en su país según su cultura. A menudo, se utiliza este argumento contra la inmigración. Bajo la actitud racista encontramos cualquier comportamiento que permita la marginación de otras personas que son aisladas por su color de piel, religión, nivel cultural...etc.

\section{Notas sobre razas y racismo}

Definición de racismo: La creencia en que hay razas, en que hay razas biológicamente superiores e inferiores, en que las razas superiores crean culturas superiores, en que las supuestas culturas superiores poseen derechos preferentes ante las otras. Es un sistema de clasificación cultural, intelectualmente ignorante, moralmente miserable, socialmente bárbaro, pero políticamente instrumentalizable.

Argumentación antiracista: 1). La idea de raza carece de fundamento biológico. 2). El prejuicio racista carece de base sociocultural. 3). El racismo es una manifestación de etnocentrismo, de nacionalismo cerrado, de clasismo, de imperialismo, de integrismo.

Morin, E., Tierra Patria.

- La separación: esta actitud promueve la lejanía entre culturas. De esta manera, las culturas se toleran (en el sentido de que no interfieren en las prácticas y costumbres de cada cual), pero se mantienen separadas, y no tienen interés en entrar en contacto.

- La actitud romántica: Representa el extremo opuesto al etnocentrismo. El romántico cultural, exagera e idealiza las características positivas de otras culturas, a las que defiende por encima de la suya propia. Uno de los inconvenientes de esta postura es que puede llevar a perder el sentido crítico, en la medida en que la cultura propuesta aparece como perfecta y no se aceptan críticas. Esto puede derivar en una indiferencia total ante la violación de los derechos humanos.

- La parálisis cultural: Esta actitud estima que lo importante es defender, proteger y conservar las propias tradiciones. Todo "contagio" cultural puede llevar a cambiar las costumbres y eso supondría una pérdida de la propia herencia cultural. Se propone una visión estática de la cultura, sin embargo, como hemos estudiado en epígrafes anteriores, la cultura está viva y es dinámica, por lo que los contactos con otras culturas pueden resultar enriquecedores y positivos. 
La posición relativista llevada al extremo puede conllevar la negación de una moralidad universal compartida por todos los seres humanos, esto es, reglas éticas y morales respetadas por todos. Pero, el relativismo cultural choca con la idea de los derechos humano. Estos, invocan un ámbito de justicia y de moralidad que está por encima de todas las culturas particulares.

\subsection{La formación de prejuicios y estereotipos.}

\section{Los estereotipos}

Si nos remontamos a la etimología de la palabra podremos captar mejor su significado. Estereotipo proviene de dos palabras griegas: stereos, que significa sólido, y typos, que significa marca. Antiguamente se utilizaba la palabra estereotipo para referirse a una técnica de impresión donde se usaba un molde para reproducir muchas veces la misma figura en papel.

Hoy esta palabra guarda algo de su significado originario, pues la utilizamos para referirnos a imágenes mentales simplificadas sobre algo o alguien que se repite y que por tanto es susceptible de ser universalizable. Así, creamos categorías para encajar a personas tomando un rasgo particular como puede ser el color de piel, sus emociones, gustos, costumbres, actitudes, y lo etiquetamos creando un estereotipo.

Los estereotipos pueden tenerse sobre otros grupos, pero también sobre uno mismo. Algunas de las características de este proceso mental son: a) es compartido por muchas personas, b) nos lleva a percibir a la persona como miembro de un grupo determinado eliminando sus particularidades, características y rasgos de su identidad personal. En resumidas cuentas, el estereotipo hace que nos olvidemos del individuo y veamos el colectivo.

Pero, ¿por qué utilizamos los estereotipos? Porque facilitan la identificación de los grupos sociales. De ahí que podamos decir que también tienen una función positiva, en tanto nos ayudan a identificarnos con un grupo, sentirnos parte del mismo y facilitarnos la inserción en él. En otras palabras, nos ayuda a saber cual es el lugar que cada uno ocupa en la sociedad. Sin embargo, en algunas ocasiones estas percepciones sobre el lugar que ocupan los otros y nosotros mismos, pueden ser falsas o superficiales, lo que crea una identificación negativa del otro.

Cabe mencionar tres tipos de estereotipos:

- Positivo: "Los catalanes son trabajadores"

- Negativo: "Los norteamericanos son superficiales"
Como viene estando de moda que el racismo, la xenofobia y los fundamentalismos religiosos son los mayores obstáculos para resolver nuestros problemas comunes. Pero la verdad es que en la base de todos ellos estará como siempre la "aporofobia". Es el pobre (el áporos) el que molesta, más que el extranjero (el xenos). El extranjero rico es siempre bienvenido: se abren las puertas al árabe rebosante de petrodólares, al judío comerciante, al gitano impuesto en la "jet". Y las mismas puertas se cierran al gitano que vende papelinas en barrios marginales, a la dominicana empleada del hogar. No va tanto la cosa en este Mar Nuestro de "xenofobia" o "racismo" ni menos aún de odios entre religiones monoteístas, engarzadas en un tronco común, tan próximas por nacimiento y por orientación vital. Va de miseria y de intentar un diálogo para superarlas, si queremos ser de verdad mediterráneos. El Mediterráneo es, desde Sócrates al menos, un lugar de diálogo, porque los mares acostumbran a valorar lo diferente y lo semejante del que viene de la otra orilla. El primer tema de ese diálogo ha de ser hoy cómo incorporar al "áporos", al necesitado, al disfrute de lo que por nacimiento le corresponde, al disfrute de una vida material y culturalmente digna.

Cortina, A., Artículo publicado en el $A B C$ Cultural.

\section{ACTIYIRADES;}

¿Qué significa aporofobia? Investiga su etimología.

¿Qué problemas podemos explicar basándonos en la aporofobia?

¿Crees que existe alguna conexión entre la aporofobia y los prejuicios? últimamente, expertos de toda laya dirán 
- Neutro: "Los gitanos tienen los ojos negros"

Finalmente, tenemos que tener cuidado con los estereotipos y aprender a diferenciar lo "negativo" o "malo" que a veces encierran, puesto que nos pueden llevar a tratar a un gran número de personas como si todas fueran iguales, generalizando y simplificando, y, por tanto, dejando de lado la diversidad individual de las personas.

\section{$>$ Los prejuicios}

Hace referencia al acto de pre-juzgar, esto de es, de elaborar, emitir o tener un juicio sin la suficiente información o conocimiento.

El prejuicio ha sido definido de diversas maneras, dependiendo de los autores:

- Heinz (1968) lo define como "un juicio emitido sin comprobar su validez por los hechos".

- Allport (1971) lo define como "una actitud hostil o prevenida hacia una persona que pertenece a un grupo suponiéndose, por lo tanto, que posee las cualidades objetables atribuidas al grupo".

- Colectivo AMANI (1994) lo define como "un juicio previo no comprobado, de carácter favorable o desfavorable, acerca de un individuo o de un grupo, tendiente a la acción en un sentido congruente".

Todas estas definiciones coinciden en un hecho: si los juicios que emitimos no son comprobados, existe una alta probabilidad de que sean falsos. Por lo tanto, el prejuicio es meramente una generalización de carácter incompleta e imprecisa, dado que es arbitrario y muy difícil de cambiar. En este sentido, los prejuicios tienen algo de irracionalidad, pues se realizan antes de mantener un contacto real, o de adquirir cierto conocimiento sobre el sujeto del prejuicio.

\subsection{El interculturalismo: una apuesta por la integración}

La posición interculturalista supera las limitaciones del etnocentrismo y del relativismo cultural, dando un paso más en dirección al diálogo y respeto entre las culturas.

El interculturalismo reconoce que la diversidad, heterogeneidad y pluralidad de las culturas es un elemento positivo que puede ayudarnos a enriquecer nuestra propia cultura. Cuando nos abrimos a los otros y establecemos relaciones basadas en la igualdad y en respeto, nos damos la oportunidad de conocernos mejor a nosotros mismos y al

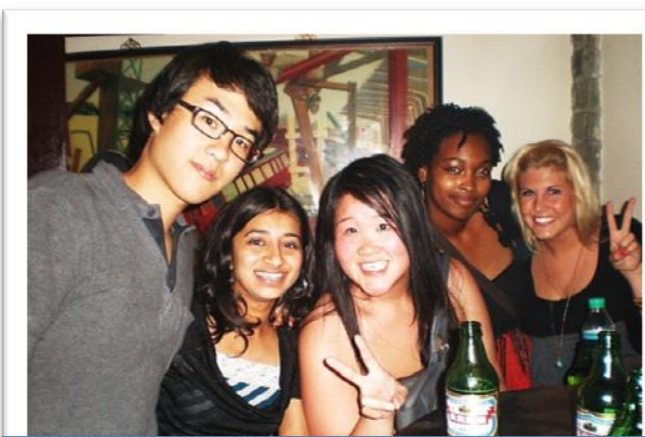

"No el Hombre, sino los hombres habitan este planeta. La pluralidad es la ley de la Tierra"

Hannah Arendt mundo en que vivimos.

Se basa, además, en la consideración de que es necesario superar la mera coexistencia territorial y buscar la convivencia a través del diálogo entre personas procedentes de diversas tradiciones 
culturales, para así poder disfrutar de las nuevas posibilidades que abre el propio diálogo. Ahora bien, el intercambio cultural, deberá darse en términos de igualdad, tolerancia y respeto.

En definitiva, el interculturalismo propone trabajar en el reconocimiento de la naturaleza plural del ser humano, de la sociedad y de nuestro mundo. Partiendo de este hecho, la actitud intercultural nos enseña a convivir con lo diferente, y a ver en el encuentro cultural, no un problema, sino la posibilidad de crecer. Porque mediante el diálogo podemos descubrir en la diversidad una fuente de recursos, y aprender que la diferencia es lo que nos complementa. El interculturalismo se presenta como una actitud que se opone a la marginación, al rechazo, a la asimilación o separación, y apuesta por la integración.

\section{El Universalismo}

El universalismo considera que la naturaleza humana es una y universal. Por debajo de la diversidad cultural, existen valores que todas las culturas compartimos. Esa naturaleza absoluta del ser humano se manifiesta en la existencia de ciertos principios, valores, normas, derechos, etc. Por ejemplo, la Declaración Universal de los Derechos Humanos, que pretende establecer los derechos inalienables de todos los seres humanos, derechos que traspasan fronteras, culturas e ideologías y que deben ser respetados y asumidos por todos.

El relativismo sostenía que no era posible la comparación entre las culturas debido a la inexistencia de unos valores compartidos por todos. En contraposición a esta idea, el universalismo propone una serie de ideales culturales independientes de toda cultura, y nacidos de una especie de razón universal. De esta manera, la comparación entre culturas se torna factible, si consideramos que la mejor cultura es la que cumple un mayor número de derechos y libertades. Mejores serían aquellas culturas que disfrutan de una mayor grado de libertad, seguridad, justicia, igualdad social y de oportunidades, educación, bienestar económico, sanidad, etc.
La diversidad cultural, patrimonio común de la humanidad.

La cultura adquiere formas diversas a través del tiempo y del espacio. Esta diversidad se manifiesta en la originalidad y la pluralidad de las identidades que caracterizan los grupos y las sociedades que componen la humanidad. Fuente de intercambios, de innovación y de creatividad, la diversidad cultural es, para el género humano, tan necesaria como la diversidad biológica para los organismos vivos. En este sentido, constituye el patrimonio común de la humanidad $y$ debe ser reconocida $y$ consolidada en beneficio de las generaciones presentes $y$ futuras.

DECLARACIÓN UNIVERSAL DE LA UNESCO SOBRE LA DIVERSIDAD CULTURAL

Ahora bien, el universalismo se enfrenta a una serie de problemáticas. En primer lugar, la noción misma de valor es harto conflictiva, ya que podríamos decir que los valores son propios de una época histórica y de un contexto cultural determinado, con lo cual no serían universales para siempre, sino sólo temporalmente. En segundo lugar, algunos detractores del universalismo han llegado a sostener que se trata de una posición que en el fondo es etnocentrista en la medida en que los valores que intenta universalizar son propios de la cultura de Occidente. Así, el universalismo intentaría expandir sus propios valores, fenómeno que contribuiría a la globalización.

En cualquier caso, el universalismo representa una posición cercana al interculturalismo ya que permite el diálogo entre las culturas, intentando evitar que unas culturas se impongan a otras. 


\section{BIBLIOGRAFÍA}

-AMANI (1994): Educación intercultural, Madrid, Editorial Popular.

-Calvo Buenzas, T (1990): El racismo que viene, Madrid, Tecnos.

-Cassirer, E (1987): Antropología Filosófica, México, F.C.E.

-Estrada Díaz, Juan A (1998): Identidad y reconocimiento del otro en una sociedad mestiza, México, Universidad Iberoamericana.

-González R. Arnaiz, G (2008): Interculturalidad y convivencia, Madrid, Biblioteca Nueva, 2008.

-Mosterín, J (1993): Filosofía de la cultura, Madrid, Alianza.

-Taylor, Ch (1993): El multiculturalismo y "Ia política del reconocimiento", México, F.C.E.

-Zubiri, X (1986): Sobre el hombre, Madrid, Alianza Editorial. 


\section{BIBLIOGRAFÍA}

\subsection{Normativa de referencia}

-LEY ORGÁNICA 2/2006, de 3 de mayo, de Educación. BOE, 4 de mayo de 2006.

-Real Decreto 806/2006, de 30 de junio, por el que se establece el calendario de aplicación de la nueva ordenación del sistema educativo. BOE, 14 de julio de 2006.

-Corrección de errores del Real Decreto 806/2006, de 30 de junio, por el que se establece el calendario de aplicación de la nueva ordenación del sistema educativo, establecida por la ley Orgánica 2/2006, de 3 de mayo, de Educación. BOE, 14 de septiembre de 2006.

-Real Decreto 1467/2007, de 2 de noviembre, por el que se establece la estructura del bachillerato y se fijan sus enseñanzas mínimas. BOE, 6 de noviembre de 2007.

-Corrección de errores del Real Decreto 1467/2007, de 2 de noviembre, por el que se establece la estructura del bachillerato y se fijan sus enseñanzas mínimas. BOE, 7 de noviembre de 2007.

-Decreto 416/2008, de 22 de julio, por el que se establece la ordenación y las enseñanzas correspondientes al Bachillerato en Andalucía.

-ORDEN de 5 de agosto de 2008, por la que se desarrolla el currículo correspondiente al Bachillerato en Andalucía.

-La Ley 17/2007, de 10 de diciembre, de Educación de Andalucía establece en su artículo 39 la educación en valores.

\subsection{BIBLIOGRAFÍA DE AULA}

\section{Libros de texto:}

-Guadiel-grupo edebé (2004): Filosofía Bachillerato, Barcelona, Guadiel.

-Conill Sancho, J., Cortina Orts, A., Domene Martinez, B., Domingo Moratalla, A., Garcia Marza, V., Martinez, N (2008): Filosofía y ciudadanía 1o de Bachiller, Madrid, Santillana.

-Lara Pérez, A., García Guzmán, J., Lama Suárez, F., Hurtado Albarrán, A (2003): Filosofía 1o de Bachillerato, Sevilla, LA N.

-González Ruiz, F. y Gonzáles Ruiz, A (2002): Filosofía, Madrid, Akal.

- Domingo, A., Domingo, T. y Feito, L (2002): Areté Filosofía 1, Madrid, SM.

- Navarro Cordón, J. y Calvo Martínez, T (2000): Serie razón y ser Filosofía 1, Barcelona, Anaya. 
* Obras de referencia:

1. Ferrater Mora, J (1982): Diccionario de Filosofía, Madrid, Ed. Alianza.

2. Copleston, F (1982): Historia de la filosofía, Barcelona, Ed. Ariel.

3. Quintanilla, M.A. (dir.) (1979): Diccionario de filosofía contemporánea, Salamanca, Ed. Sígueme.

* Bibliografía básica para el desarrollo de la U.D:

- García Castaño, F.J. y Granados Martínez, A (1999): Lecturas para educación intercultural, Madrid, Trotta.

- González R. Arnaiz, G (2008): Interculturalidad y convivencia, Madrid, Biblioteca Nueva.

(2002): El discurso intercultural. Prolegómenos a una filosofía intercultural, Madrid, Biblioteca Nueva.

* Algunas lecturas:

- Voltaire, (1997): Tratado sobre la tolerancia, Madrid, Santillana.

- Tournier, M (1986): Viernes o los limbos del Pacifico, Madrid, Alfaguara.

- Freud, S (1999): El malestar de la cultura, Madrid, Alianza.

- Harris, M (1993): Jefes, cabecillas, abusones, Madrid, Alianza Cien.

- Tuiavii de Tiavea (1989): Los Papalagi, Integral ediciones, Barcelona.

- Estrada Díaz, Juan A. (1998): Identidad y reconocimiento del otro en una sociedad mestiza, Universidad Iberoamericana, México.

- SODEPAU (2004): Educar en la diversidad. Materiales para una acción educativa intercultural, Catarata, Madrid.

- AMANI (1994): Educación intercultural, Editorial Popular, Madrid.

- Calvo Buenzas, T (1990): El racismo que viene, Tecnos, Madrid.

- Cassirer, E (1987): Antropología Filosófica, F.C.E., México.

- Giddens, A (1995): La constitución de la sociedad: Bases para la teoría de la estructuración, Amorrortu, Buenos Aires.

- Mosterín, J (1993): Filosofía de la cultura, Alianza, Madrid.

- Taylor, Ch (1993): El multiculturalismo y "la política del reconocimiento", F.C.E., México.

- Zubiri, X (1986): Sobre el hombre, Alianza Editorial, Madrid. 


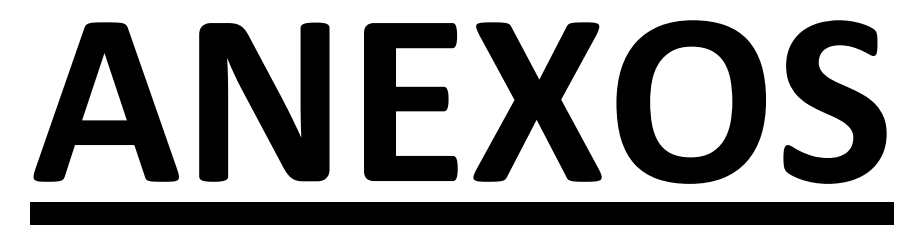


Materiales para llevar a cabo el desarrollo de las actividades previstas:

Sobre los grupos de contracultura (SESIÓN CUARTA):

Canción de Nach, "El reino de lo absurdo":

http://www.youtube.com/watch?v=P4M1se00o4k

Para el tema del racismo (SESIÓN QUINTA):

\section{LA GENÉTICA DESCALIFICA EL CONCEPTO DE RAZA}

NATALIE ANGIER (NYT), NUEVA YORK (13-09-00)

Calibrar la inteligencia, las aptitudes o el carácter por el color de la piel es algo que para amplios grupos de expertos se aleja de la realidad científica. Los investigadores que han completado la secuencia del genoma humano sostienen que el de raza es un concepto social pero no científico. "Hay una sola raza, la humana", afirman. Por el contrario, otros grupos de investigadores insisten en que hay tres razas principales con diferencias fundamentales que se extienden al cerebro y a su capacidad intelectual.

Aun considerando que la investigación sobre el genoma humano está en sus albores, los partidarios de una única raza sólo ven en los rasgos diferenciales externos procesos de adaptación al medio que se explican por un número pequeñísimo de genes. Los científicos sospechan desde hace tiempo que las categorías raciales reconocidas por la sociedad no se reflejan en el plano genético. Cuanto más de cerca examinan los investigadores el genoma humano -el material genético incluido en casi todas las células del cuerpo-, más se convence la mayoría de ellos de que las etiquetas habituales utilizadas para distinguir a las personas por su raza tienen muy poco o ningún significado biológico. Los investigadores afirman que aunque pueda parecer fácil decir a simple vista si una persona es caucásica, africana o asiática, la facilidad desaparece cuando se comprueban características internas y se rastrea el genoma del ADN en busca de signos relacionados con la raza. El resultado es, dicen los científicos, que la especie es tan joven desde el punto de vista evolutivo, y sus patrones migratorios son tan amplios, permanentes y complicados, que sólo se ha tenido oportunidad de dividir en grupos biológicos separados o razas en los aspectos superficiales. "La raza es un concepto social, no científico", afirmó J. Craig Venter, director de Celera Genomics Corporation, en Rockville, Maryland. "Todos evolucionamos en los últimos 100.000 años a partir del mismo grupo reducido de tribus que emigraron desde África y colonizaron el mundo".

Venter y los científicos de los Institutos Nacionales de la Salud anunciaron recientemente que habían obtenido un borrador de la secuencia completa del genoma humano, y los investigadores declararon unánimemente que hay una sola raza: la raza humana. Afirman que los rasgos más comúnmente utilizados para distinguir una raza de otra, como el color de la piel y de los ojos, o el ancho de la nariz, son rasgos controlados por un número relativamente pequeño de genes, y por lo tanto han podido cambiar rápidamente en respuesta a presiones ambientales extremas durante el corto curso de la historia del Homo sapiens. 


\section{REFLEJO MÍNIMO}

"Si se pregunta qué porcentaje de genes está reflejado en la apariencia externa, sobre la que nos basamos para establecer la raza, la respuesta es aproximadamente del 0,01\%", dice Harold P. Freeman, del Hospital General de Manhattan, que ha estudiado la cuestión de la biología y la raza. "Este es un reflejo mínimo de nuestra composición genética", añade Freeman. "Desgraciadamente para la armonía social, el cerebro humano está exquisitamente sintonizado con las diferencias en los detalles del envoltorio, induciendo a las personas a exagerar la importancia de lo que se ha dado en llamar raza", afirmó Douglas C. Wallace, profesor de genética molecular en la Universidad de Emory, en Atlanta. "Los criterios que la gente utiliza para determinar la raza se basan completamente en características externas que estamos programados para reconocer", dijo. Wallace sostiene que la razón por la que estamos programados para reconocer esas características viene de la importancia vital que representa para nuestra especie el que cada uno de nosotros distinga a un individuo de otro. Según establecen los científicos, en contraste con el mínimo número de genes que hacen que unas personas tengan la piel oscura y los ojos almendrados, y otros tengan la piel blanca como la cal, rasgos como la inteligencia, el talento artístico y las aptitudes sociales probablemente están formados por miles, si no decenas de miles, de los aproximadamente 80.000 genes que forman el genoma humano, todos trabajando de una forma combinatoria compleja.

Pero no todos los investigadores consideran la raza como una noción carente de significado o antediluviana. "Creo que las clasificaciones raciales nos han resultado útiles", afirmó Alan Rogers, especialista en genética de poblaciones y profesor de Antropología en la Universidad de Utah, en Salt Lake City. "Podemos creer que la mayoría de las diferencias entre razas son superficiales, pero las diferencias están ahí, y nos informan sobre los orígenes y las migraciones de nuestra especie". Hay un grupo de investigadores que siguen insistiendo en que entre las tres razas principales hay diferencias fundamentales que se extienden al cerebro. J. Philippe Rushton, psicólogo de la Universidad de Ontario Occidental en Canadá, y autor del libro Race, evolution and behaviour (Raza, evolución y comportamiento), es quizá el más incansable partidario de la creencia de que las tres razas principales difieren genéticamente en aspectos que afectan al cociente intelectual medio del grupo y a la propensión hacia el comportamiento criminal. Afirma que su trabajo revela que los asiáticos orientales tienen el mayor tamaño cerebral medio y mayor cociente intelectual; los de ascendencia africana tienen el tamaño medio cerebral más pequeño y el menor cociente intelectual; y los de ascendencia europea están en el medio.

\section{EL TAMAÑO DEL CEREBRO}

Pero muchos científicos han puesto objeciones a sus métodos e interpretaciones, alegando, entre otras cosas, que el vínculo entre el tamaño total del cerebro y la inteligencia no está nada claro. El cerebro de las mujeres, por ejemplo, es más pequeño que el de los hombres, incluso después de realizar correcciones para tener en cuenta su menor masa corporal, y sin embargo, las puntuaciones medias de cociente intelectual masculinas y femeninas son iguales. Por lo mismo, las pruebas fósiles indican que los neandertales tenían un cerebro muy grande, y ni siquiera duraron lo suficiente como para inventar pruebas homologadas. Eric S. Lander, experto en genoma del Whitehead Institute en Cambridge, Massachusetts (EE. UU.), admite que, dado que la investigación sobre el genoma humano 
acaba de comenzar, no puede descartar definitivamente a aquellos que argumentan que las diferencias raciales significativas se deben reflejar en alguna parte del ADN humano y que se encontrarán cuando los investigadores las busquen en serio. Pero, en opinión de Lander, los 113 que mantienen que dichas divisiones raciales existen son los que tienen la causa más difícil de defender. Aunque la investigación de la estructura y secuencia del genoma humano está todavía en pañales, los genetistas han elaborado un esbozo de la historia genómica humana, generalmente llamada la hipótesis de fuera de África o de la evolución de Eva. Según esta teoría, el Homo sapiens se originó en África hace entre 200.000 y 100.000 años aproximadamente, y comenzó a emigrar a Oriente Próximo, Europa, Asia y, a través de la masa de tierra de Bering, hacia América. Según avanzaban, parecen haber desplazado en su totalidad o en gran medida a humanos arcaicos que ya habitaban en los diversos continentes, bien mediante actos calculados de genocidio, o simplemente reproduciéndose en mayor medida, hasta conducirlos a la extinción. Sin embargo, el genoma humano es muy grande; está compuesto por unos 3.000 millones de subunidades o bases, lo que significa que incluso un porcentaje minúsculo de variación de un individuo a otro supone un importante número de diferencias genéticas. La cuestión es en qué parte del genoma se encuentra esa variación y cómo se distribuye entre las diferentes poblaciones.

Mediante muestras genéticas mundiales de marcadores genéticos neutrales tramos de material genético que no ayudan a crear las proteínas que hacen funcionar el cuerpo, sino que por el contrario están compuestos del denominado ADN silencioso (los intrones), los investigadores han descubierto que, de media, el $88-90 \%$ de las diferencias entre las personas se producen dentro de sus poblaciones locales, mientras que sólo aproximadamente el 10-12\% de las diferencias distinguen a una población, o una raza, de otra. Dicho de otra manera, los pobladores de cualquier aldea del mundo, ya sea en Escocia o en Tanzania, tienen el $90 \%$ de la variabilidad genética que la humanidad tiene para ofrecer. Pero esa relación de $90 / 10$ es sólo una media, y únicamente hace referencia a los marcadores de ADN silencioso. Para el material genético que codifica las proteínas, el cuadro es un poco más complejo. Muchos genes trabajadores (los exones), responsables de las funciones básicas de los órganos, no muestran prácticamente ninguna variabilidad de un individuo a otro, lo que significa que son incluso menos específicos de cada raza que los marcadores genéticos neutros.

\section{POBLACIONES}

Algunos genes, notablemente los del sistema inmune, muestran una variabilidad enorme, pero esa variabilidad no se adapta a los diferentes grupos raciales. Y finalmente están los genes que controlan la pigmentación y otras características físicas. Éstos también se sirven en un amplio surtido de sabores, pero al contrario que los genes relacionados con la inmunidad, a menudo se distribuyen en grupos específicos de población, lo que da como resultado que los suecos se parezcan mucho más a otros suecos que a los aborígenes australianos.

Algunas diferencias grupales superan la profundidad de la piel. Entre los ejemplos más famosos están los elevados índices de anemia falciforme entre los norteamericanos de ascendencia africana, y del síndrome de Cooley, otra enfermedad relacionada con la hemoglobina, entre los descendientes de pobladores mediterráneos. Ambos rasgos se desarrollaron para ayudar a los antepasados de estos grupos a resistir la infección por malaria, pero ambos resultan letales cuando se heredan por partida 
doble. En cuanto a las diferencias en la pigmentación de la piel, la presión del medio ambiente para desarrollar un rasgo grupal generalizado era poderosa. En opinión de Freeman, la ciencia de los orígenes humanos puede ayudar a curar algunas heridas, y eso, dice, es una justicia dulce. "La ciencia nos metió en este problema, con sus mediciones de los cráneos y su énfasis en las diferencias y en las clasificaciones raciales", dice Freeman, y añade: "Los científicos deberían sacarnos ahora de ese atolladero. Tienen que ser líderes a la hora de promover la evolución del conocimiento sobre la raza humana".

\section{Para el tema del Hijab (SESIÓN SEXTA):}

\section{Cortometraje de Xavier Sala}

http://www.youtube.com/watch?v=10TcXyEhr_o

\section{Ensayo sobre símbolos religiosos en la escuela:}

\section{Símbolos religiosos en la escuela: el caso del velo musulmán.}

El presente ensayo tiene como objetivo abordar la problemática nacida en torno al velo islámico en los espacios públicos, en concreto en la escuela. Para poder ofrecer una opinión fundamentada al respecto, en primer lugar se aborda el hijab desde un punto de vista general, esto es, atendiendo a su condición de signo religioso, así como al resto de simbologías-funcionalidades que encierra. Luego se hace alusión a la idea de pudor, en la medida en que se trata de un sentimiento que fundamenta la usabilidad de la prenda, a la vez que legitima su postura voluntaria. De esta manera, al comienzo del trabajo, se intercalan argumentos a favor y en contra del hijab, fundamentando y refutando posturas e idearios (I). A continuación, se procede a analizar el caso del velo en la escuela, partiendo de la idea de que, la escuela es un espacio público de enseñanza de respeto, de tolerancia y convivencia (II). Finalmente, se ofrece una conclusión fundamentada en todo lo expuesto anteriormente, y que parte de la idea de la moderación como principio base y condición necesaria, que garantiza el equilibrio y armonía de la sociedad democrática (III).

\section{PROHIBICIÓN Y ACEPTACIÓN, DEBATE SOBRE EL USO DEL HIJAB}

tu cuerpo me inquieta, tu mirada me alarma, escóndete mujer, porque tu poder, me espanta.

Érika Fiuri 
Existen varios caminos que pueden llevarnos a la condición de exiliados, y de la misma manera, existen distintos modos de ser un exiliado. Uno de ellos, quizás el que ocurre con mayor frecuencia, y que por ello tenemos más identificado, es aquel en el que las personas deben dejar su país y marchar a una tierra diferente. Otra manera de convertirse en un exiliado, se corresponde con el exilio social, ser excluido, vuelto invisible para los demás, no reconocidos. Pero existe una tercera forma, que se configura en el interior de las personas, y al que nos podemos referir como exilio de uno mismo. En esta tercera forma, nuestra vida interior pierde riqueza, a la vez que nos abandonamos y desvalorizamos la estima que sentimos hacia nosotros mismos.

La mujer, se ha visto sometida por mucho tiempo a estas clases de exilio, y la problemática del velo islámico nos lleva a centrarnos en las dos últimas formas: exilio social y exilio interior. A continuación haremos una incursión en el pensamiento occidental y su postura frente al hijab.

Desde la postura prohibicionista, a saber, aquella que interpreta que el velo encubre una situación social de dominación de la mujer, de negación de libertad, se considera que el uso del hijab debe reducirse al ámbito privado y ser excluido de los espacios públicos. Y la fundamentación última de esta creencia, se arraiga en el hecho de pensar que cuando las mujeres se ponen el velo, legitiman la dominación patriarcal, convirtiendo sus cuerpos en un objeto de control. Sin embargo, el asunto es más complejo, y se haya enrevesado en una maraña conceptual difícil de elucidar. Para empezar, la postura prohibicionista juzga desde los patrones culturales y los valores occidentales. Afirma lo que está bien y lo que está mal, lo que debe y no debe hacerse, y erige una normativización de la vestimenta desde lo que se considera que es lo apropiado. En otras palabras, nos cuesta acercarnos al asunto del velo, desde la otra mirada. Pero ¿qué es lo vemos? ¿Qué ve Occidente en esas mujeres que llevan velo?

Ven un mecanismo de politización islámica, una forma de islamizar a Europa. Por lo tanto, la aceptación del velo supondría un triunfo para el enemigo, que no es un país sino un movimiento con objetivos de expansión y en contra de los valores occidentales. El velo se erige como un arma que utiliza a la mujer para librar una batalla política.

La aparición del burka y su prohibición son el signo de que el pacto secreto y tácito entre los islamistas y el poder acaba de romperse. La prohibición supone una declaración de guerra a los islamistas a través de su ala salafista. Este episodio permite comprobar una vez más que los velos, hoy bajo sus formas radicales, ayer bajo sus formas refinadas, ni vienen de ni conducen al cielo. Son los marcadores de oscuras guerras por la conquista del poder. Guerras que, tanto entonces como ahora, se dirimen sobre el cuerpo de las mujeres (Tamzali, W. 2010: 87).

Otra interpretación podría llevarnos a desestimar esta visión. En efecto, si partimos del hecho más que constatado y estudiado ${ }^{2}$ - de que el uso del velo no es inherente al Islam, sino que se trata de una costumbre anterior a la propia religión islámica y no exclusiva de la misma, y por tanto de carácter secular, nos encontramos con que el velo no puede ser considerado una herramienta política, sino una práctica cultural. Así, el velo sería un símbolo que coadyuvaría a manifestar el entresijo cultura-religión-tradición.

Por otro lado, pero en íntima relación con lo anterior, la interpretación prohibicionista que considera que el velo es un modo de politización del Islam, sitúa a la mujer como campo de batalla, devaluando su autonomía y su capacidad de reflexión. De ahí que el velo haya sido

\footnotetext{
${ }^{2}$ Un análisis al respecto, nos lo ofrece Vicente Llorent Bedmar, quien explica que "esta secular costumbre existía en Oriente Próximo, donde mucho antes de que esta religión apareciera en la faz de la Tierra ya se usaba con profusión. Prueba de tal circunstancia lo constituye la Ley asiria atribuida al Teglatfalasar (1116-1078 a. C.), que data aproximadamente del s. XII a. C., y de la que aún se conservan dos series de tablillas (Fatás, 2008)" (Llorent Bedmar, V. 2009: 99).
} 
reivindicado por muchas mujeres como un signo de libertad. Abordaremos con mayor detenimiento este punto ya que es sumamente importante.

Desde esta perspectiva, el velo supone una legitimación del espacio público como perteneciente a la mujer en igual medida que al hombre. No hace mucho tiempo, este debate se situó en la lucha de las feministas occidentales ${ }^{3}$, que reclamaban la inclusión de la mujer en el espacio público, antaño definido con patrones varoniles, y especialmente agresivo con las mujeres, que eran recluidas a la esfera privada, al ámbito doméstico. En este sentido, al velarse, las mujeres se sienten legitimadas para acceder a la esfera pública, trabajar y asumir toda clase de roles, sin perder el recato, el pudor. El velo se nos presenta como eje vertebrador de los dos espacios.

Esta disertación nos lleva a centrarnos en un punto que, a mi parecer, es clave: el pudor. Resulta cuanto menos, curioso, el hecho de que prácticamente no existan trabajos que profundicen la conexión existente entre la vestimenta del hijab y el sentimiento del pudor ${ }^{4}$.

Una de las diversas razones por la que las mujeres deciden portar el pañuelo, radica en la idea de preservar el pudor, término que no debemos confundir con la vergüenza. Porque el pudor puede ser definido como el mecanismo que pone a salvo nuestra intimidad, que protege nuestra integridad, que permite que nos manifestemos, que nos expresemos, pero que impide la exhibición. Se considera así, que "lo bello es lo que viene de la intimidad y trae consigo armonía y capacidad de reunión" (Polo, L. 1991: 5). De esta manera, cuando la mujer lleva hijab preserva su pudor y salvaguarda su intimidad para sí misma. Se aleja de las miradas de los hombres y participa de la vida pública siendo valorada y respetada por su capacidad intelectual y su modestia.

Pudor y modestia, son dos sentimientos que también se refieren al modo de vestir de la mujer honesta cristiana. En el Diccionario de uso del español de María Moliner, "pudor" se define como:

-“Vergüenza de exhibir el propio cuerpo desnudo... de ser objeto en cualquier forma de interés sexual o de hablar de cosas sexuales. Modestia, recato. Castidad, decencia, decoro, honestidad, miramiento, modestia, pudibundez, pudicicia, recato, recogimiento, respetos.

- Sentimiento que aparta de exhibir cualquier cosa íntima". (Moliner, M. 1998: Tomo II, 877)

Mientras que la definición de "modesto", aclara lo siguiente:

-“Aplicado a las mujeres.

-Se dice de la que cuida de que su comportamiento, en el aspecto de las relaciones con el otro sexo, no sea libre o provocativo". (Moliner, M. 1998: Tomo II, 434)

Vemos cómo el sentimiento de pudor se asocia con la vergüenza y con la castidad, y a la vez va de la mano de la idea de modestia, referida al recato ante los hombres. Por otro lado, la Biblia también dictamina cómo deben vestirse las mujeres y los hombres, aclarando que se ha de utilizar una "ropa decorosa":

1 Timoteo 2:9-10

\footnotetext{
${ }^{3}$ En esta línea destacan los trabajos de Iris Marion Young, en concreto La justicia y la política de la diferencia, 2000, Madrid, Cátedra.

${ }^{4}$ Para un análisis del pudor y la vergüenza desde la fenomenología, ver el trabajo de Max Scheler Sobre el pudor y el sentimiento de vergüenza, 2004, Sígueme, Salamanca.
} 
"Asimismo que las mujeres se atavíen de ropa decorosa, con pudor y modestia; no con peinado ostentoso, ni oro, ni perlas, ni vestidos costosos, sino con buenas obras, como corresponde a mujeres que profesan piedad".

\section{Pedro 3:3-4}

"Vuestro atavío no sea el externo de peinados ostentosos, de adornos de oro o de vestidos lujosos, sino el interno, el del corazón, en el incorruptible ornato de un espíritu afable y apacible, que es de grande estima delante de Dios."

Los matices son diferentes en las recomendaciones que dictaminan cada religión, sin embargo, los preceptos del recato en la vestimenta son similares. Podría decirse que la mujer occidental lejos de seguir estos ideales se ha separado de ellos y ha ido creando un nuevo imaginario estético. Desde la semiótica de la moda, se analiza el uso del corsé como una cárcel para el espíritu puro de las mujeres, o el uso del pantalón como un modo de "habilitar" el cuerpo femenino para realizar labores de hombres. Lo que pretendo decir, es que la moda se ha deslindado de la religión, y sigue sus propias reglas y caprichos. En el caso de la vestimenta musulmana, el hijab es moda, religión, política, cultura, tradición. Se trata de una prenda polifacética que adquiere el significado que su portadora quiera darle. En este punto es importante resaltar, que el velo, pese ha haberse comercializado y ser una prenda que las mujeres eligen con cuidado, que combinan con el resto de su ropa, no es una simple moda. Algunos creen que el hijab obedece a los designios de la moda y que por tanto tiene fecha de caducidad. Sin embargo, sus raíces y significaciones en muchos casos encierran componentes identitarios. De esta manera, podemos ver que tiene otra dimensión que convierte al hijab en expresión de la individualidad, lo que nos hace pensar que lejos de desaparecer, su uso se extenderá.

Pero el discurso prohibicionista del velo, puede decir algo al respeto: el hijab es una forma de discriminación sexual, de dominación del hombre sobre la mujer, en la medida en que el peso de mantener la identidad recae única y exclusivamente en las mujeres. Son ellas las que deben ataviarse acorde a lo que dictaminan sus maridos, mientras que los hombres visten al modo occidental. Con lo cual, no se trataría de una seña de identidad adoptada libre y voluntariamente por las portadores del velo, sino de una manera de ser controladas y utilizadas.

Desde que la "polémica" del velo ha saltado a los medios de comunicación, muchas mujeres que usan el velo han sido entrevistadas. En un reportaje de El País Semanal, el periodista Álvaro Corcuera, recoge las confesiones de mujeres de todas las edades que han decidido llevar el velo. Un comentario en particular, llamó mi atención:

\section{MARIAM OSORIO}

Nació en una familia católica de Fuenlabrada (Madrid) hace 22 años. Con 19 se convirtió al islam. Con 20 se puso 'hiyab'. Y con 21 se casó.

"Me preguntan si me comieron el tarro. Me sienta mal. Parece que soy manipulable, que me creo a cualquiera. Gracias al Corán no paso un día sin decir 'te quiero' a mi madre. Mi padre no me entiende" (El País Semanal, 2010: 36).

Si la mujer se pone el velo, es porque se lo dice su marido o su hermano. Esta afirmación cosifica a la mujer hasta el punto de convertirla en un ente carente de raciocinio. Mariam Osorio lo expresa muy bien, las mujeres no somos manipulables, pensamos y tenemos poder de elección, y aquellas 
mujeres que no pueden elegir, que son obligadas a llevar el velo, son las mujeres que sufren y sobre las que tenemos que volcar nuestro discurso y actuación. Así pues, se debería actuar sobre la imposición, y no sobre la libre elección.

\section{EL HIJAB EN LA ESCUELA}

"Estoy dispuesta a luchar por esta tela. No es una gorra. Esto es fe. Si hace falta dejar la carrera, la dejaré. Esto es sentimiento y detrás no va ni un padre, ni una madre, ni un hermano, ni un marido"

SHAIMA AMAZZAL

La discusión sobre el velo ha desvelado una supuesta necesidad de normativización de su uso. Y el posicionamiento de los actores sociales y políticos ha ido produciéndose, desde que saltaran las alarmas con el caso de Pozuelo. Desde aquél episodio en el que finalmente primó el derecho de los centros a regular y establecer la indumentaria de sus estudiantes. Se dijo entonces que, al igual que no se permitían gorras, o enseñar ropa interior, estaba prohibido llevar velo dentro del recinto escolar.

En primer lugar, podemos reflexionar acerca de la equiparación que se hace entre el velo, una prenda que hemos analizado en el apartado anterior, intentando demostrar algunos de sus significados/funciones, y una gorra, o lo que es peor, ropa interior. La respuesta de muchos dirigentes políticos ante el caso de la joven Najwa fue prohibicionista, y se fundamentó en el reglamento que ampara a los centros educativos, pero también fueron discursos poco meditados y bastante exaltados, que en ningún caso se planteaban qué era el velo, su significado, la posibilidad de ser tratado como algo diferente a la indumentaria occidental. Pero estas preguntas ya han llegado al escenario público y van de la mano de la idea de regularizar el uso de la prenda, esto es, dictaminar leyes que nos digan qué debemos hacer cuando la tolerancia desaparece, cuando incomprendemos al Otro y no queremos hacer ningún esfuerzo de integración.

Sin embargo, este proceso legislativo, este prescribir leyes sobre los cuerpos, como si estos fuesen tabulas rasas, objetos que deben ir de una manera u de otra. Cubiertas, si lo dictaminan sus hombres, descubiertas si lo dice el Estado, ¿̇en que lugar queda la decisión de la mujer? ¿Acaso no sería tal imposición impropia de un Estado laico que promulga la libertad religiosa? Se argumenta que la prohibición del velo acabaría con una situación de dominación, de sexismo que infravalora a la mujer. Pero cuando la sociedad Occidental prohíbe su uso, también ejerce dominación, una dominación de los cuerpos, cuyo fin es la asimilación.

Aquellos políticos que "defendieron" y lo digo entre comillas porque fueron discursos muy moderados, antepusieron el derecho a la educación, afirmando que poco importaba si las adolescentes llevaban velo o no, dado que lo importante era si estaban recibiendo lo que les corresponde por derecho constitucional.

Pero continuemos indagando sobre la idea de la regulación del velo. Nos encontramos con que la promulgación de las leyes de este nuestro Estado laico, tienen que estar montadas sobre los derechos civiles, para proteger a los ciudadanos. Por ello, no cabría una normativización del velo, porque el hijab es algo que atañe a lo religioso y las leyes deben prescribirse sobre lo civil. Por otro 
lado, dejar en manos de los institutos la prohibición o aceptación del velo, parece una carga excesiva para los centros.

En todo caso, lo que debemos tener presente es que la esfera pública es una esfera plural, y como tal, ha de responder a la diversidad y garantizar el diálogo y el orden, manteniendo y respetando los derechos fundamentales de todos. Y la escuela, como eje transversal de lo público y lo plural, por decirlo con Labaca Zabala, debe:

preservar y asegurar la legalidad del cambio, ya que estamos en presencia de un lugar especialmente privilegiado en el que se adquieren y transmiten los valores comunes de la sociedad, que tienen su base en la igualdad de los niños y niñas, quienes deben respetar y preservar la laicidad de la escuela de la República. Sólo la neutralidad de la escuela puede asegurar el respeto de la libertad de conciencia de los alumnos, así como, el respeto de todo tipo de convicciones (Labaca Zabala, 2008: 2).

En esta medida la escuela democrática tiene la obligación, por principios, de impulsar y promover el respeto de los unos a los otros, fomentando pautas de conducta propias de la sociedad democrática. Enseñando que somos iguales, pero diferentes y que esa diferencia es algo muy positivo para nuestro desarrollo cultural, social e individual. Mostrando que el respeto y la tolerancia son valores esenciales para lograr una convivencia pacífica y solidaria. Se trata de fomentar la comprensión, y a la vez el sentido de la crítica y la autocrítica que no permitan caer en el relativismo del todo vale, ni en una postura genérica de aceptación indiscriminada.

\section{CONCLUSIONES}

El presente trabajo ha pretendido perfilar las dos posturas dominantes sobre el velo islámico, a saber, la postura prohibicionista y aquella que lo acepta. Para ello, se han ido hilvanando los argumentos e intentando dar respuestas plurales, a la vez que iba construyendo mi propia opinión sobre el hijab.

En el camino de elaboración del ensayo, me he ido dando cuenta de la abrupta complejidad del tema, de las múltiples variantes que encierra y de lo difícil que resulta abordarlo desde una posición monocausal. A su vez, me ha sorprendido la escasez de materiales en los que se pudiera encontrar argumentos a favor del velo en general, y mucho menos en los espacios públicos. Inclusive, debatiendo la problemática con algunos profesores y compañeros he podido reconocer el rechazo absoluto que genera el hijab.

Un argumento que me sorprendió fue el siguiente: hay religiones que no tienen cabida en una democracia. Cuando las mujeres vienen a la universidad con pañuelo, se las respeta, pero cuando tú vas a Casablanca a dar una conferencia, te obligan a ponértelo.

Analizando este comentario, lo primero que detectamos es una contradicción, dado que en la democracia todas las religiones y culturas tienen cabida, en la medida en que uno de los valores principales de la misma es garantizar derechos para todos, entre los que podemos constatar el derecho a la libertad religiosa. En segundo lugar, hay que distinguir entre imposición y tradición o costumbre. Si en las universidades de Casablanca o Marruecos se acostumbra a usar velo, deberíamos respetar esa tradición, porque desde nuestra cultura no significa nada que atente contra 
nuestros derechos el utilizarlo, máxime cuando sabemos que su no uso, nos hace parecer desnudas a los ojos de las mujeres que lo portan, es más una cuestión de pudor, como he querido dejar reflejado antes, que de imposición arbitraria.

En conclusión, al ser este un tema de una complejidad extrema, adopto ante él una posición moderada, porque la moderación es condición para la libertad. En los espacios multiculturales que configuran nuestras sociedades, la posibilidad de vivir pacíficamente es actuando en todos los ámbitos con la moderación pertinente, como afirma Dassetto, conviene tener presente que esta moderación de la expresión pública -religiosa o de toda identidad colectiva- es también la condición de la libertad individual (Dassetto, F. 2003: 3).

La libertad se configura como el requisito irrenunciable al que debemos aspirar todos los ciudadanos de un Estado de Derecho. Por lo tanto, creo que las mujeres con velo o sin él, deben poder optar a ese derecho, y profesar con libertad su religión, siempre y cuando lo hagan con moderación y sin afectar los derechos de otras personas. Por otro lado, me sitúo firmemente en contra del burka o niqab, ya que sumen a la mujer en la ausencia y le privan de la mirada, gesto importante para ser reconocido por el Otro. Y respeto al hijab, si encubre alguna forma de dominación o imposición, tampoco estoy a favor. Pero si se trata de una prenda de autoafirmación de la propia persona, elegido y voluntario, lo acepto y respeto. Nuestra sociedad intercultural necesita reafirmar los valores de respeto y de aceptación de lo diferente, siempre y cuando, las prácticas en cuestión se hallen legitimadas por la democracia.

\section{BIBLIOGRAFÍA}

A parte de los materiales facilitados para la realización de este ensayo, se han consultado las siguientes fuentes:

ALBACETE, Catalina (et. al.) (2000): Enseñar y aprender la democracia, Madrid, Síntesis.

APPLE M. W. y BEANE, J. A (1997): Escuelas democráticas, Madrid, Morata.

DASSETTO, F. (2003): Debates sobre la gestión del Islam en Europa, Madrid, Med.

DELCAMBRE, Anne-Marie (2006): Las prohibiciones del Islam, Madrid, La esfera de los libros.

LABACA ZABALA, María L (2008): La prohibición del velo islámico en los centros educativos de Francia: límite el principio de laicidad de la república, Universidad del País Vasco.

LLORENT BEDMAR, V. (2009): Utilización de signos religiosos en los centros escolares de Alemania y Reino Unido: el velo islámico, Educación XX1, Núm. 12, UNED, pp. 97-121

POLO, Leonardo (1991): El significado del pudor, Conferencia en la Universidad de Piura.

RAMÍREZ, Ángeles (2011): La trampa del velo, Madrid, Catarata.

TAMZALI, Wassyla (2010): El burka como excusa, Madrid, Saga. 


\section{Para el debate sobre multiculturalismo (SESIÓN OCTAVA):}

"Vine a España cuando era muy joven, casi un crío. Conocía a otra gente que había venido. En mi familia no me querían dejar venir. Entré en España sin ningún tipo de documentación. No sabía bien lo que quería: era al mismo tiempo aventura y buscar una vida mejor. [...]

Normalmente no me siento discriminado por la gente. Yo siento discriminación en el Gobierno. ¿Por qué no quieren aceptarnos como a unos ciudadanos más? ¿Por qué la policía siempre va a por nosotros? Cuando hay algún magrebí que hace algo mal, todos tenemos que pagarlo. ¿Por qué? [...]

Me he encontrado con gente que me decía que lo yo hacía en mi religión era una tontería. Decir que el Ramadán con su ayuno es una tontería, ¿’por qué? Yo les he dicho: si te interesa saber algo de mis creencias, dime: "Enséñame algo de tu cultura y de tu religión". Yo te voy a explicar por qué lo hago. Y cuando te lo haya explicado, quizás conocerás algo más y podrás opinar mejor. Yo creo que todas las religiones vienen a creer en el mismo Dios. Yo respeto la vuestra; respetad también la mía.

[...] A veces he pensado en volver allá...Soy de allí, y siento los problemas que mi gente vive allí, problemas muy duros. Pero también me siento de aquí. [...] No quiero el sufrimiento para otros. Ves a la otra persona que sufre y es como si algo de esto te pasase a ti. Aunque pienses de manera muy distinta, aunque tengas otra religión."

(Fragmentos de una entrevista hecha por Joan Soler a Alí, un inmigrante magrebí) 


\section{Modelos de exámenes posibles:}

\section{EXAMEN TEMA 6: Naturaleza, cultura y el reto intercultural. 19 DE BACHILLERATO}

1).- ¿Por qué el ser humano puede ser definido como un ser cultural? ¿Qué quiere decir que necesita reconocimiento y relaciones intersubjetivas para desarrollarse plenamente?

2).- ¿Somos sociales por naturaleza? Responde señalando las teorías de Aristóteles, Hobbes y Rousseau y exponiendo sus diferencias.

\section{3).- Marca con una cruz la respuesta correcta.}

1). El proceso de socialización supone:
a) adquisición de conocimientos.
b) formación de vínculos afectivos.
c) formación como personas.
d) todas son correctas.

2). La socialización secundaria:
a) es inconsciente.
b) tiene una implantación muy firme.
c) se da en la infancia.
d) no es exclusiva de una etapa concreta de la vida.

3). Es constante en todas las culturas que el primero y más importante agente socializador sea:
a) la familia.
b) la escuela.
c) el grupo de iguales.
d) los medios de comunicación.

4).- ¿En qué se diferencia la subcultura de la contracultura? Indica un ejemplo argumentado de cada caso.

\section{5).- Comentario de texto.}

“Desde esta encrucijada [la construcción europea ante las olas de inmigrantes] se apuntan, a grandes rasgos, dos caminos. El primero es eminentemente defensivo e implica el desarrollo de lo que, con anterioridad he llamado el espíritu de la fortaleza. Se trata de un movimiento de defensa a partir del cual Occidente, y en particular Europa, quiere prolongar su futuro partiendo restrictivamente de sus raíces. Para decirlo de una manera cruda: partiendo de la superioridad del etnocentrismo practicado por la raza blanca, de la verdad superior de la religión cristiana, de la riqueza excluyente de la cultura occidental, de la eficacia única del liberalismo...La insistencia en este camino unanimista entraña naturalmente el reforzamiento de un modelo de trincheras frente a la amenaza exterior. Las consecuencias lógicas son el autoritarismo defensivo y el racismo".

Argullol, R. y Trías, E., El cansancio de Occidente. 
a).- Explica la idea fundamental y desarrolla tus conocimientos sobre el tema.

b).- ¿Cuál crees que es el "otro camino" que puede tomar Occidente?

EXAMEN TEMA 6: Naturaleza, cultura y el reto intercultural. 1을 BACHILLERATO

1).- Define el término cultura señalando todas sus características.

2).- Marca con una cruz la respuesta correcta.

1). Según Aristóteles:

a) vivir en sociedad es una exigencia de la naturaleza humana.

b) el ser humano es un "animal político".

c) el ser humano es el único ser dotado de naturaleza moral.

d) todas son correctas.

2). Según Thomas Hobbes el hombre en el estado de naturaleza:
a) posee una piedad natural.
b) ataca a otros por ganancias, seguridad y reputación.
c) está dotado de moralidad y puede distinguir entre lo bueno y lo malo.
d) no desea la paz.

3). El proceso de socialización supone:
a) adquisición de conocimientos.
b) formación de vínculos afectivos.
c) formación como personas.
d) todas son correctas.

3).- Explica qué es la socialización primaria, secundaria y la resocialización. Pon un ejemplo argumentado de cada una.

4).- Define los términos "subcultura" y "contracultura". Indica cómo calificarías los siguientes grupos, de subcultura, contracultura o de ninguna de las dos cosas y explica por qué.

- Grupo de inmigrantes que viven en un centro de acogida.

- Grupo de skin heads.

- Comunidad judía de Madrid.

- Grupo de acción ecologista.

-Poblado de gitanos en las afueras de una gran ciudad. 
5).- Comentario de texto.

"Los integrantes de cada grupo étnico no solían poner en cuestión las soluciones de su propia cultura y, en la escasa medida en que tuvieron noticia de las demás, se trataba de una noticia vaga, deformada y peyorativa. Al erigir sus propias soluciones culturales en estándares o patrones con que juzgar las culturas ajenas, no es de extrañar que éstas resultasen minusvaloradas e incluso ridiculizadas. En cualquier caso se daba la autocomplacencia cultural...Lo erróneo, lo grotesco, lo perverso y lo degenerado se daba entre los demás. Esta actitud constituye el etnocentrismo".

a).- ¿Qué actitud está definiendo el texto?

b).- Explica la idea fundamental y desarrolla tus conocimientos sobre el tema.

\section{EXAMEN TEMA 6: Naturaleza, cultura y el reto intercultural. 10 DE BACHILLERATO}

1).- Define la teoría de Thomas Hobbes e indica otra teoría que postule lo contrario.

2).- Marca con una cruz la respuesta correcta.

1). El aprendizaje durante la socialización primaria:

a) no es cognoscitivo pero tiene carga emocional.

b) es cognoscitivo con enorme carga emocional.

c) es cognoscitivo sin carga emocional.

d) ninguna es correcta.

2). La resocialización:

a) se asemeja a la socialización primaria.

b) tiene una implantación muy firme.

c) supone un desmantelamiento de la anterior perspectiva.

d) todas son correctas.

3). Es constante en todas las culturas que el primero y más importante agente socializador sea:
a) la familia.
b) la escuela.
c) el grupo de iguales.
d) los medios de comunicación.

3).- Define los conceptos de prejuicio y estereotipo. Indica un ejemplo de cada uno.

4).- ¿Es lo mismo subcultura que contracultura? Señala las diferencias e indica un ejemplo argumentado de cada caso. 
5).- Comentario de texto.

“Decía antes que el racismo, como todo prejuicio cultural, tiene como referencia el etnocentrismo. Puede que podamos hablar de un etnocentrismo normal, el que nos permite pensar y actuar en un marco de referencia. Pero sabemos que nuestras convicciones, hábitos, pautas, prácticas, son nuestras, no normales ni naturales. Lo normal y natural, es fuera de toda duda, la variedad",

San Román, T., "Pluralidad y marginación".

a).- ¿Qué es el etnocentrismo? ¿Cuáles son sus manifestaciones?

b).- Explica la idea fundamental y desarrolla tus conocimientos sobre el tema.

EXAMEN TEMA 6: Naturaleza, cultura y el reto intercultural: 1 DE BACHILLERATO (RECUPERACIÓN)

\section{1).- 2 puntos}

¿Cuál es la diferencia entre el individualismo posesivo y el individualismo altruista? ¿Qué quiere decir el individualismo posesivo cuando afirma que "Lo que hace humano a un hombre es ser libre de la dependencia de las voluntades de los demás"?

2).- 2 puntos.

Explica la posición de Aristóteles y la de Rousseau respecto a la génesis social del ser humano. ¿Qué sistema político apoya Hobbes? ¿Por qué?

3).- 2 puntos.

¿En qué se diferencia la socialización primaria de la resocialización? Explica la socialización secundaria y pon un ejemplo argumentado.

4).- 2 puntos.

Define la subcultura y la contracultura. Pon un ejemplo de cada caso.

5).- Comentario de texto. 2 puntos.

"Decía antes que el racismo, como todo prejuicio cultural, tiene como referencia el etnocentrismo. Puede que podamos hablar de un etnocentrismo normal, el que nos permite pensar y actuar en un marco de referencia. Pero sabemos que nuestras convicciones, hábitos, pautas, prácticas, son nuestras, no normales ni naturales. Lo normal y natural, es fuera de toda duda, la variedad",

San Román, T., "Pluralidad y marginación".

¿Qué es el etnocentrismo? ¿Cuáles son sus manifestaciones?

Comenta el texto y explica la diferencia entre una posición relativista y otra universalista. 